ФЕДЕРАЛЬНОЕ ГОСУДАРСТВЕННОЕ БЮДЖЕТНОЕ УЧРЕЖДЕНИЕ НАУКИ ИНСТИТУТ ЕВРОПЫ

РОССИЙСКОЙ АКАДЕМИИ НАУК

Е. П. Тимошенкова

ПАРТИЙНО-

ПОЛИТИЧЕСКАЯ

GИСTEMA

TEPMAHIU⿴囗十

В ПЕРИОД

КАНЦЛЕРСТВА

А. МЕРКЕЛЬ

/2005-2017 гг.l

MOCKBA

ИE PAH

2020 
Федеральное государственное бюджетное учреждение науки

Институт Европы

Российской академии наук

\author{
Е.П. Тимошенкова
}

\title{
ПАРТИЙНО-ПОЛИТИЧЕСКАЯ СИСТЕМА ГЕРМАНИИ В ПЕРИОД КАНЦЛЕРСТВА А. МЕРКЕЛЬ (2005-2017 гг.)
}

Монография

Доклады Института Европы № 369

Москва

ИЕ РАН

2020 
УДК 329(430)"2005/2020"

ББК 66.69(4Гем)

T41

Редакционный совет:

Ал.А. Громыко (председатель),

Е.В. Ананьева (шеф-редактор), Ю.А. Борко,

В.В. Журкин, М.Г. Носов, В.П. Фёдоров

Ответственный редактор к.э.н. В.Б. Белов, редакторы к.филос.н. Е.В. Ананьева, Е.В. Дрожжина

Рецензенты:

Васильев Виктор Иванович, доктор политических наук Гуселетов Борис Павлович, доктор политических наук

Тема НИР 0191-2019-0005

«Комплексные исследования экономического, политического и социального развития стран Западной Европы, Украины, Арктического региона на современном этапе»

Тимошенкова Е.П. Партийно-политическая система Германии в период канцлерства А. Меркель (2005-2017 гг.) - A party political system in Germany at the time of Angela Merkel' chancellorship (2005-2017) : монография / Е.П. Тимошенкова. - М. : Ин-т Европы РАН, 2020. 148 с. - (Доклады Института Европы = Reports of the Institute of Europe / Федеральное гос. бюджетное учреждение науки Ин-т Европы Российской акад. наук ; № 369) - Парал. тит. л. англ. - ISBN 978-598163-154-2.

В монографии исследуются основные тенденции развития партийно-политической системы ФРГ, особенности стиля управления первой женщины - канцлера, её влияние на современное состояние партийно-политического ландшафта Германии и его будущее.

Мнение авторов может не совпадать с мнением редакционного совета.

DOI: http://dx.doi.org/10.15211/report22020_369

(C) ИЕ РАН, подготовка текста, 2020 
Russian Academy of Sciences

Institute of Europe RAS

E.P. Timoshenkova

\title{
THE GERMAN PARTY POLITICAL SYSTEM DURING ANGELA MERKEL'S \\ CHANCELLORSHIP \\ (2005-2017)
}

\author{
Monography \\ Reports of the Institute of Europe \\ № 369
}

Moscow

IE RAS

2020 


\section{Аннотация}

Монография представляет собой комплексное исследование партийно-политической системы Германии в период канцлерства А. Меркель с 2005 по 2017 гг. Автор анализирует особенности стиля управления А. Меркель, её политику как канцлера ФРГ и председателя ХДС, выявляет основные тенденции трансформации германских политических партий: ХДС, ХСС, СДПГ, СвДП, «Союза 90/Зелёные», «Левой», «Альтернативы для Германии». Особое внимание в работе уделено анализу избирательных кампаний и итогов выборов в бундестаг и земельные ландтаги. Дан прогноз развития партийно-политической системы Германии в будущем, исходя из итогов деятельности А. Меркель.

\section{Annotation}

The monograph represents a complex research of the party political system of Germany during the A. Merkel regime from 2005 to 2017. The author analyses special aspects of the Chancellor's management, her politics as Chancellor and as the leader of CDU, uncovers basic transformation tendencies of German political parties: CDU, CSU, CDPG, SVDP, «Alliance 90/The Greens», «The Left», «Alternative for Germany». A special emphasis is put on the analysis of the electoral campaigns and election results to the Bundestag and Landtags. Finally a projected growth of the party political system of Germany resulting from the activities of A. Merkel. 


\section{СОДЕРЖАНИЕ}

Введение....................................................7

1. Партийно-политическая система ФРГ .................... 10

2. Предвыборная кампания 2005 г. и первые итоги деятельности большой коалиции........................ 14

3. Выборы в бундестаг 2009 г. и правление чёрно-жёлтой коалиции.................................. 30

4. Значение земельных выборов 2011 г. для политических партий ФРГ

5. Влияние политических скандалов на партийную систему Германии....................... 46

6. Конец политического католицизма в ФРГ? ......................... 50

7. Создание новой партии «Альтернатива для Германии»......55

8. Подготовка к выборам в бундестаг 2013 г................. 56

9. Выборы в бундестаг 2013 г.: итоги и особенности..........68

10. Немецкая партийно-политическая система после 2013 г. ....................................85

11. 2017 год - год выборов в Германии..................... 106

12. Формула власти А. Меркель........................... 127

Заключение.................................................. 133

Основная литература....................................... 139

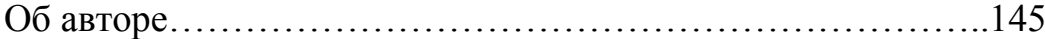




\section{CONTENS}

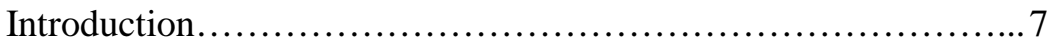

1. Party System of FRG .................................... 10

2. Electoral Campaign of 2005 and the First Results of the Activities of the Grand Coalition........................ 14

3. Elections of 2009 to the Bundestag and Ruling of the «Black and Yellow» Coalition.............................30

4. Significance of State Elections of 2011 for Political Parties of Germany......................................... 34

5. Impact of Political Scandals on a Party System of Germany.... 46

6. The End of the Political Catholicism in FRG?............................. 50

7. Creation of a New Party «Alternative for Germany»............55

8. Electoral Campaign before the Elections of 2013 to the Bundestag............................................ 56

9. Elections of 2013 to the Bundestag: Outcomes and Particularities......................................... 68

10. German Party System after the Elections of $2013 \ldots \ldots \ldots \ldots \ldots . .85$

11. 2017 - Election Year in Germany..........................106

12. A. Merkel' Formula of Power..............................127

Conclusion............................................... 133

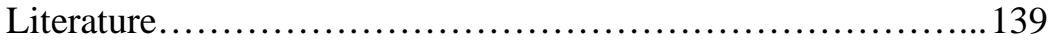

About the Author............................................. 145 


\section{ВВЕДЕНИЕ}

Политические партии и партийная система ФРГ переживают серьёзные изменения. Процесс продолжается давно, однако более заметно он стал проявляться с 2005 г. - выборов в нижнюю палату парламента, в результате которых у власти оказалась большая коалиция - ХДС/ХСС и СДПГ, а канцлером Германии впервые стала женщина, представительница бывшей ГДР Ангела Меркель. После перерыва в 2009-2013 гг. была вновь сформирована большая коалиция. Её возврат даёт основания говорить о начале некоего переходного периода - периода неопределённости в развитии партийно-политической системы ФРГ. Станет ли союз двух народных партий политической обыденностью для немецкого избирателя или ему придётся привыкать к новым коалициям? Как на развитие ХДС, и тем самым других партий повлиял приход в большую политику А. Меркель? Какую роль в этом процессе играют малые партии?

Долгое время политическая система ФРГ - с правления К. Аденауэра и до канцлерства Г. Коля - базировалась на двух основных принципах: стабильная партийная система и политика социального компромисса. За исключением краткого периода в истории страны - первого издания большой коалиции (19631966 гг.) - ХДС/ХСС или СДПГ всегда удавалось образовать необходимое парламентское большинство с одной из малых партий. Вплоть до 2003 г. - партийного съезда ХДС в Лейпциге и принятия программы СДПГ «Повестка дня 2010»- действовала и другая политическая формула: никаких экспериментов с немецким социальным государством, чтобы не утратить большинство на выборах. Историческая особенность Германии заключается в том, что она была разделена в результате холодной войны на ФРГ и ГДР. Они оказались втянутыми в долгосрочное соревнование за звание «лучшего государства», что привело к установлению высоких социальных стандартов, от которых немецкие избиратели уже объединённой Германии не желают отказываться до сих пор. В результате народные партии вынуждены постоянно обращаться к идее «социальной справедливости» и стремиться оправдывать высокие ожидания граждан. 
Объединение немецкого государства, вызовы глобализации и обременённый долгами государственный бюджет привели крупные политические партии к осознанию потребности в глубоких и основательных реформах и тем самым к смене парадигмы в истории ФРГ, результатами которой стали изменения партийно-политической системы. Основная дилемма политических партий Германии, прежде всего ХДС/ХСС и СДПГ, в начале XXI в. заключается в необходимости, с одной стороны, вовремя реагировать на проблемы, стоящие перед немецкой социально-экономической моделью (предлагать и проводить действенные, но, как правило, не популярные у населения реформы), с другой - успешно бороться за власть, привлекая на свою сторону избирателей.

Эволюция партийно-политической системы объединённой Германии всегда находилась в фокусе российских исследователей. Наиболее последовательный исторический анализ этой научной проблемы представлен в трудах Н.В. Павлова ${ }^{1}$. Автор подробно рассматривает вопросы политического лидерства в условиях «канцлерской демократии» и роль А. Меркель как главы немецкого государства ${ }^{2}$. Влияние личного фактора на внутриполитическое развитие Германии можно проследить в работах В.И. Васильева, который отдельное внимание уделяет трансформации СДПГ . Вопросы развития малых партий, лево-

1 Павлов Н.В. История современной Германии. 1945-2005. М., АСТ, 2006. С. 74; Павлов Н.В. Эволюция партийной системы ФРГ: роль малых партий. Роль малых партий в партийно-политической системе Германии. Под ред. В.Б. Белова, Е.П. Тимошенковой. Сер. Доклады Института Европы, М., 2015. С. 2849; Павлов Н.В. «Союз 90/Зелёные»: история, состояние, перспективы. Мировая экономика и международные отношения, 2011, №3. С. 37-45; Павлов Н.В. Германский федерализм: опыт реформирования. Мировая экономика и международные отношения, 2007, №10. С. 53-63; Павлов Н.В. Нормальная и «ненормальная» Германия. Международная жизнь, 2005, №11. С. 15-31.

2 Павлов Н.В. Политическое лидерство в условиях канцлерской демократии. Мировая экономика и международные отношения, 2011, №11. С. 25-38; Павлов Н.В. Меркель 4.0 - это реальность! Historia provinciae - журнал региональной истории, 2018, Т. 2. №2. С. 80-90; Павлов Н.В. Германия после Меркель (Ждать ли изменений во внешней политике ФРГ?). Полис. Политические исследования, 2019, №6. С. 22-35.

${ }^{3}$ Васильев В.И. Германский политик Герхард Шрёдер. Новая и новейшая история, 2014, №6. С. 145-157; Васильев В.И. «Меркализация» СДПГ: отход от «восточной политики» В. Брандта. Международная жизнь, 2018, №9. С. 47-64; 
го и правого популизма исследует С.В. Погорельская ${ }^{4}$. Детальный анализ причин возникновения право-популистской партии «Альтернатива для Германии» и ее влияния на немецкую политику проводит А.К. Камкин ${ }^{5}$. Внутриполитические последствия объединения ГДР и ФРГ и проблемы формирования единой идентичности в Германии после воссоединения подробно рассматривает в своих работах М.В. Хорольская ${ }^{6}$ Таким образом, в современной российской политологической науке представлен широкий спектр мнений по вопросам развития немецких партий и эволюции партийного ландшафта Германии.

В предлагаемой вниманию читателя монографии анализируется развитие партийно-политической системы ФРГ и её внутренней политики с 2005 по 2017 гг. Выбранный для исследования период позволяет проследить итоги деятельности больших коалиций для немецкого государства, сравнить причины их образования в разные периоды и выявить последствия их взаимодействия для трансформации партийного ландшафта Германии, раскрыть «секрет» политического долголетия первой женщиныканцлера. В работе особое внимание уделено анализу выборов в бундестаг и земельные парламенты, мотивам голосования не-

Васильев В.И. Гельмут Коль. Прагматик, патриот, европеец. Международная жизнь, 2017, №7. С. 43-53.

${ }^{4}$ Погорельская С.В. Левая альтернатива для Германии. Актуальные проблемы Европы, 2019, №4. С. 78-92; Погорельская С.В. Современный германский популизм: общее и особенное. Перспективы. Электронный журнал, 2019, №4 (20). С. 92-102; Погорельская С.В. «Альтернатива для Германии»: без внутренней альтернативы? Перспективы. Электронный журнал, 2018, №1(13). С. 40-55; Погорельская С.В. Опыт и уроки германской иммиграционной политики. Актуальные проблемы Европы, 2015, №4. С. 61-84.

${ }^{5}$ Камкин А.К. «Альтернатива для Германии» как новый элемент партийного ландшафта. Современная Европа, 2015, №2(62). С. 118-122; Камкин А.К. «Альтернатива для Германии» - партия-однодневка или серьёзная сила? Современная Германия. Экономика и политика. Под ред. В.Б. Белова. М., 2015. С. 533-539; Камкин А.К. «Альтернатива для Германии» - прообраз народной партии нового типа? Германия. 2014. Под ред. В.Б. Белова. М., 2015. С. 51-61. ${ }^{6}$ Хорольская М.В. Проблемы формирования единой идентичности в Германии после воссоединения. Этносоциум и межнациональная культура, 2017, №3(105). С. 158-162; Хорольская М.В. Различия в политической культуре Востока и Запада Германии в условиях кризисов ЕС. Мировая экономика и международные отношения. 2017. Т. 61. № 9. С. 100-110; Хорольская М.В. Преодоление прошлого и переосмысление истории ГДР в современной Германии. Россия и современный мир, 2019, №1(102). С. 133-147. 
мецких граждан и влиянию политических лидеров на эти процессы. Вопросы внешней политики и взгляды партий на роль Германии в международных отношениях автор сознательно не рассматривает, т.к. эта самостоятельная тема заслуживает отдельного изучения. Монография выполнена на основе ранее опубликованных материалов.

\section{1. ПАРТИЙНО-ПОЛИТИЧЕСКАЯ СИСТЕМА ФРГ}

Изменения в современной партийно-политической системе ФРГ экспертное сообщество воспринимает драматично уже потому, что невольно сравнивает сегодняшние тенденции с достижениями «Боннской республики». Их главным результатом стало преодоление «исторической раздробленности» партийной системы Веймарского периода, расщепления партий и соответственно политической нестабильности. Возможность образования правительственных коалиций, состоящих из двух партий большой и малой, стала главным признаком устойчивости созданной системы и тем самым необходимой предпосылкой для проведения государством экономического и политического курса, который позволил Германии восстановиться после Второй мировой войны и занять достойное место в европейском сообществе. Значительный вклад в это развитие внесла партия ХДС, которую в разное время возглавляли К. Аденауэр, Л. Экхард, К. Кисингер, Г. Коль и А. Меркель.

Однако стабильная трёхпартийная политическая система, состоящая из двух больших и одной малой партии, в итоге определяющей, кто из них окажется у власти, существовала в ФРГ не всегда. В первом немецком бундестаге было представлено 12 партий и два независимых депутата ${ }^{7}$. Концентрация и превращение в трёхпартийную систему происходили постепенно и пришлись в основном на 1950-е гг. Этому способствовали, прежде всего, введение в 1953 г. 5\%-ного избирательного барьера

\footnotetext{
* Материал данной главы был опубликован в: Тимошенкова Е.П. «Партийная система Германии в эпоху перемен». Современная Германия: экономика и политика. Под ред. В.Б. Белова. Москва, Институт Европы РАН, Весь мир, 2015. C. 454-494.

${ }^{7}$ Павлов Н.В. История современной Германии. 1945-2005. М., АСТ, 2006. С. 74.
} 
и интеграционная привлекательность Христианско-демократического союза, в который вошли многие мелкие партии. По этой причине количество значимых партий, с которыми можно было арифметически образовать правительство, сильно сократилось. В результате в 1957 г. христианские демократы оказались единственными победителями, против которых невозможно было создать коалицию, поскольку им принадлежало большинство мест в парламенте. Однако то был единичный случай в истории Федеративной Республики Германии. Сложившаяся в 1950-е гг. трёхпартийная политическая система получила своё дальнейшее развитие в 1960-1970-е гг. Именно в период с 1965 по 1975 гг. на ХДС/ХСС и СДПГ приходилось более 90\% всех депутатских мандатов в бундестаге. И только в 1983 г. с прохождением в парламент «зелёных» количество партий, способных составлять правительственные коалиции, увеличилось до четырёх.

\section{1. Появление партии «Левая» и её влияние на немец- кую партийно-политическую систему}

С объединением немецкого государства и избранием в бундестаг представителей Партии демократического социализма (ПДС) формат партийно-политической системы Германии начал претерпевать существенные изменения. ПДС сумела преодолеть 5\%-ный барьер только в 1998 г., набрав 5,1\% (ранее она была представлена в парламенте благодаря депутатам, избранным по прямым спискам), количество арифметически возможных коалиций из пяти парламентских партий значительно увеличилось. Таким образом, на левом фланге от социал-демократов появилась новая политическая сила, потенциально способная привлечь на свою сторону часть избирателей СДПГ, что привело к более значимым последствиям для эволюции партийно-политической системы Германии в целом, чем сам факт этаблирования новой партии. Вместе с тем бывшая правящая партия ГДР довольно быстро преобразовалась: в декабре 1989 г. к прежнему наименованию «Социалистическая единая партия Германии» (СЕПГ) добавилось название «Партия демократического социализма», которое спустя шесть недель, в феврале 1990 г., стало новым обозначением партии. Летом 2005 г. ПДС была преобразована в «Партию левых» с дополнением «ПДС» и сокращённым 
названием «Левая», которое с июня 2007 г. после объединения с западногерманской избирательной альтернативой «За труд и социальную справедливость» стало основным названием партии ${ }^{8}$.

Фактически до федеральных выборов в 2005 г. ПДС не представляла собой общегерманскую политическую партию: за неё отдавали голоса в основном избиратели т.н. новых федеральных земель, которые ранее входили в состав ГДР. Заявить о себе как о реальном политическом факторе на земельном уровне партия смогла в 1994 г., поддержав красно-зелёное правительство меньшинства в Саксонии-Ангальт. Вплоть до 2002 г. ПДС не удавалось набрать более $2 \%$ на западе Германии. Только с 2005 г., когда «левые» смогли получить в старых землях и в западной части Берлина 4,9\%, можно говорить о начале долгосрочного этаблирования партии в общегерманском масштабе и о превращении её в конкурентоспособную политическую силу.

Появление партии «Левая» привело не просто к арифметическому росту количества партий в парламенте, но и к уменьшению мобилизирующей и интеграционной силы народных партий, прежде всего, Социал-демократической партии Германии. Доля так называемых постоянных избирателей, которые регулярно голосуют за одну и ту же партию, сократилась, а изменчивость электорального поведения возросла. Стремление СДПГ и ХДС завоевать большинство голосов на выборах и конкуренция за одни и те же социальные группы привели к сближению их избирательных программ и утрате чёткого политического профиля в глазах избирателя.

Со времени правления Г. Шрёдера СДПГ повернула в сторону неолиберализма и во многом стала ориентироваться на крупный бизнес и его экспортные интересы, в то время как ХДС под руководством А. Меркель совершила более успешный манёвр влево. Желание этих партий привлечь на свою сторону бо́льшую часть общества и стать партиями т.н. «середины» (политического центра) привело к тому, что другие социальные слои стали выпадать из их охвата и искать поддержки своих интересов у ма-

${ }^{8}$ См. подробнее: В.С. Рыкин, А.А. Вильде, Е.П. Тимошенкова. Создание левой альтернативы на базе ПДС и движения «За труд и социальную справедливость». Германия. Вызовы XXI века. Под ред. В.Б. Белова. М., Весь Мир, 2009. C. $154-163$. 
лых партий, ориентирующихся на конкретного избирателя.

\section{2. Структурные изменения в обществе и мотивы элек- торального поведения}

Кризису народных партий, который стал заметно проявляться после пребывания ХДС/ХСС и СДПГ в большой коалиции в 2005-2009 гг. способствуют, на наш взгляд, и изменения, происходящие в самом обществе. Оно стало более индивидуализированным. Сегодня избиратель ориентируется не на общую направленность и риторику партий, а на то, какие решения предлагают эти партии по конкретным, волнующим его вопросам. Подобный индивидуалистический подход уже сам по себе идёт вразрез с идеей партии как коллективной организации, нацеленной охватить своей программой возможно больше избирательных групп. В современном обществе готовность избирателя надолго идентифицировать себя с какой-либо из партий заметно снижается. Рекрутировать новых сторонников партиям становится всё сложнее, так как целевые группы распадаются на группы по интересам, которые быстро меняются. Социально-структурные признаки постепенно заменяются стилем жизни. Как следствие происходит эрозия привычных связей партии с её организациями.

К тому же научно-технический прогресс и смена поколений ведут к изменениям в методах избирательной борьбы. Партии превратились в рекламный продукт: их имидж в СМИ определяет стратегию успеха. Умение преподнести себя и правильно подать обществу свои достижения становится для современных политиков более важным фактором, чем их профессиональная компетентность. В подобных условиях ещё больше возрастает роль личности в политике и увеличивается влияние средств массовой информации на принятие политических решений, что нередко приводит к промедлению и нерешительности со стороны элиты и отрицательным последствиям для политического процесса в целом. 


\section{2. ПРЕДВЫБОРНАЯ КАМПАНИЯ 2005 Г. И ПЕРВЫЕ ИТОГИ ДЕЯТЕЛЬНОСТИ БОЛЬШОЙ КОАЛИЦИИ*}

К федеральным выборам 2005 г. правящая коалиция из СДПГ и «Союза 90/Зелёные» подходила с неутешительными итогами: безработица достигла 5 млн чел., из которых 1,1 млн чел. приходился на Северный Рейн-Вестфалию, традиционную вотчину социал-демократов, а экономический рост составлял всего 1\%. Для сравнения - накануне предыдущих выборов в бундестаг численность безработных составляла 4 млн чел. Немецкому избирателю не приходилось напоминать, что свои первые выборы Г. Шрёдер выиграл, пообещав сократить безработицу до 3,5 млн.

Как показала предвыборная кампания 2005 г., в решении этой наиболее актуальной для немцев проблемы программные подходы ведущих партий ХДС и СДПГ не нашли широкой поддержки у избирателей. Реформы социал-демократов, не успели привести к положительным результатам. А. Меркель предложила механистический подход - уменьшить безработицу через ограничение притока рабочей силы. Однако общеизвестно, что иностранцы трудятся в тех отраслях и на тех позициях, которые представляются немцам непривлекательными.

Невозможность обуздать безработицу была обусловлена системным конфликтом между сформированной германской моделью социального государства и усилившимся конкурентным давлением внешней среды при значительном повышении динамики общественных и социально-экономических процессов. В этих условиях любой немецкий Кабинет вне зависимости от состава участников становился заложником социального государства. Там молодой специалист, только поступая на работу, на примере своих родителей уже рассчитывал, каким образом он будет тратить свою будущую пенсию. На воспроизводство негибкой, порождающей социальный инфантилизм и при этом одобряемой обществом модели, работала и германская система

\footnotetext{
*Материал данной главы частично был опубликован в: В.С. Рыкин, А.А. Вильде, Е.П. Тимошенкова. Особенности внутренней политики. Германия. Вызовы XXI века. Под ред. В.Б. Белова. М., Весь Мир, 2009. С. 163-183.
} 
образования, исправно выпуская «в никуда» армию академических конформистов, пополняющих ряды безработных.

С другой стороны, сложившуюся систему подтачивали глобальные интеграционные процессы. Благодаря активности «зеленых» в продвижении разрешительной миграционной политики не только усилилась конкуренция на немецком рынке труда, но приобрели качественно новое звучание проблемы культурной ассимиляции, межкультурной интеграции и социализации. По официальным данным, только за один 1992 г. в ФРГ переселилось в четыре раза больше беженцев, чем в остальные страны Европейского союза.

В сложившихся неблагоприятных для себя условиях канцлер Г. Шрёдер предпринял нестандартный ход, предложив досрочные выборы и, тем самым, продемонстрировав избирателям, что не держится за своё кресло, а вместе со всеми старается найти выход из кризиса. Демарш главы красно-зелёного кабинета разрушил стратегию оппозиции, нацеленную на постепенное «удушение» правительственной коалиции. Социал-демократы фактически вынудили блок ХДС/ХСС сделать ставку на не пользующуюся большой поддержкой у населения А. Меркель. Её оценивали как далеко не лучшего кандидата в лидеры нации. «Гэдээровское» прошлое, отсутствие харизмы в сравнении с яркой фигурой канцлера Г. Шрёдером - минусы, которые должны были повысить шансы социал-демократов остаться у власти. Неожиданный ход, связанный с назначением досрочных парламентских выборов, позволил СДПГ серьёзно изменить формат избирательной кампании и в результате пусть не победить, но и не проиграть.

Центральными сюжетами в предвыборной повестке оказались проблемы германской экономики и миграционные процессы. Однако попытка обсудить реальные рецепты оздоровления в условиях острого политического соперничества в очередной раз разбилась о желание политиков одержать победу любой ценой. Христианские демократы во многом растеряли своё преимущество вследствие изначального стремления сказать избирателю правду. Непопулярной шрёдеровской «Повестке дня 2010» они противопоставили ещё более радикальный подход 
профессора П. Кирххова, экономического консультанта А. Меркель. Его рецепты выхода из кризиса были достаточно стандартны для формирующейся глобальной динамичной конкурентной среды и предполагали введение плоской шкалы 25\%-ного подоходного налога, увеличение НДС на 2\%, и соответственно, рост цен, отмену многочисленных налоговых льгот, приватизацию пенсионных систем.

С экономической точки зрения, цели были вполне понятными: противодействовать уходу производства в регионы более «дешёвых рук», повысить инвестиционную привлекательность германской экономики, придать рынку труда более современный и динамичный характер за счёт прямых трудовых договоров между работодателями и служащими в противовес тарифным соглашениям. Воспользовавшись самоуверенностью конкурентов, социал-демократы прибегли к технологии «подмены объекта», провозгласив, что социальное бесправие наступит в результате реализации программы П. Кирххофа, а не предложенной ими «Повестки дня - 2010». Инициативы финансового эксперта ХДС немедленно подверглись красно-зелёной обструкции как несоответствующие традиционным немецким принципам справедливости. Социал-демократы и их союзники усмотрели в них попытку «уравнять медсестру и миллионера» и окрестили «политикой социального холода и экологического застоя». Предвыборная позиция СДПГ формулировалась в более социально приемлемых тезисах: продолжение реформы системы социальных гарантий, содействие повышению занятости населения за счёт инвестиций в образование и науку, повышение налогов на богатых граждан с годовым доходом свыше 250 тыс. евро.

Однако на этот раз естественное предвыборное стремление Г. Шрёдера сыграть роль защитника социальных гарантий немцев (а различные виды соцпомощи в Германии в общей сложности получал 41\% взрослого населения) не обеспечило СДПГ ожидаемых дивидендов. Помимо его собственной «Повестки дня», предусматривавшей сокращение пенсий, урезание социальных пособий и льгот, перестройку системы здравоохранения, манёвр социал-демократов существенно ограничили «левые». Для них образ партии как гаранта социальных прав граждан 
стал центральным, и потому тема социальной справедливости из уст их лидеров - О. Лафонтена и Г. Гизи прозвучала гораздо убедительнее.

Осознав, что намеченная стратегия не способна полностью переломить настроения немцев, социал-демократы решили дискредитировать имидж кандидата в канцлеры от блока ХДС/ХСС. Супруга Г. Шрёдера Дорис публично указала на такие факты биографии А. Меркель как бездетность и наличие развода: по её мнению, они свидетельствовали о недостатке у Меркель необходимого жизненного опыта, присущего большинству женщин. В дальнейшем это обвинение преобразовалось в позиционирование лидера ХДС не как «политика будущего», а как «фантома из прошлого»: «Те, кто провалился в 1990-х гг., не могут преуспеть», - предупреждал Г. Шрёдер, «бездетная и разведённая» фрау Меркель повинна в снижении рождаемости в стране в свою бытность министром по делам женщин и молодёжи», негодовала Дорис Шрёдер 9 .

Христианские демократы не остались в долгу: их лидер А. Меркель обвинила канцлера СДПГ в намерении создать предвыборную коалицию с участием партии «Левая» - аргумент, который будет использован и на последующих выборах. Категорический отказ самого Г. Шрёдера от подобной возможности А. Меркель в расчёт не принимала, приводя в пример альянсы социал-демократов и левых в Восточной Германии. Однако основной стратегией оппозиции стала критика безрезультатности 7-летнего нахождения у власти представителей красно-зелёной коалиции. «Живётся ли нашей стране лучше, чем семь лет назад, когда к власти пришло это правительство? Растёт ли экономика? Уменьшается ли безработица? Стало ли меньше бюрократии? Являются ли ваши пенсии, уход в старости и здравоохранение более гарантированными?» - спрашивала соотечественников А. Меркель ${ }^{10}$.

На фоне конфронтации ХДС и СДПГ значительных успехов на выборах в бундестаг 2005 г. добились малые партии. СвДП

\footnotetext{
9 «Меркель - недальновидный и опасный политик, Шрёдер - человек из прошлого». The Financial Times, 08.09.2005.

10 Там же.
} 
набрала 9,8\% голосов, увеличив своё представительство в бундестаге на четверть. Этот результат связан, во многом, с бескомпромиссной позицией лидера партии Г. Вестервелле. Впервые после ухода из большой политики выдающегося политического деятеля Г.-Д. Геншера у либералов появилось собственное яркое политическое лицо, благодаря которому многие сторонники ХДС/ХCС перешли в лагерь либералов.

То же самое произошло и на левом фланге партийно-политического ландшафта Германии. Радикальные сторонники социал-демократов предпочли проголосовать за партию «Левая», состоящую из наиболее решительно настроенного крыла СДПГ и ПДС. Новые «левые» получили по итогам выборов 8,7\% голосов, завоевав рекордные 54 мандата вместо двух мест ПДС в бундестаге предыдущего созыва. В этой связи европейские аналитики пришли к выводу, что в Германии впервые за всю послевоенную историю вслед за Францией и Италией появилась «общенациональная левая партия».

Больше других партий голосов на выборах получил блок ХДС/ХСС (35,2\%,). Но высокого результата либеральных демократов оказалось недостаточно для создания с ними коалиции. Не собрали необходимого количества голосов и социал-демократы (34,2\%) с «зелёными» $(8,1 \%)$. По итогам проведённых 18 сентября 2005 г. всеобщих выборов и довыборов 2 октября в Дрездене мандаты в бундестаге распределились следующим образом: ХДС/ХСС - 226, СДПГ - 222, СвДП - 61, «Союз 90/Зелёные»-51, «Левая»-54 места ${ }^{11}$. Таким образом, ни у ХДС/ХСС с СвДП, ни у СДПГ с «зелёными» не оказалось большинства, чтобы самостоятельно, без «третьей силы» сформировать правящую коалицию. Союз с недавно образованной «Левой» ни одна из сторон в расчёт не принимала.

Ситуация усугублялась ещё и тем, что бывший канцлер Г. Шрёдер после оглашения первых итогов выборов заявил, что их результаты не дают права кандидату на пост канцлера от ХДС А. Меркель формировать правительство. «Никто кроме меня не в состоянии сформировать стабильное правительство. Я веду

${ }^{11}$ Bundestagswahl 2005. URL: http://stat.tagesschau.de/wahlarchiv/wid246/index. shtml (дата обращения: 08.08.2019). 
переговоры, и они будут успешными», - подчеркнул Шрёдер ${ }^{12}$. И хотя эти заявления носили больше демагогический характер и были призваны вызвать нервозность у основного соперника, некоторое время было неясно, какая из партий возглавит страну. Единственным выходом из кризиса, приемлемым для обеих политических сил, стало создание большой коалиции. Такой прецедент уже имелся в германской истории в 1967-1969 гг., когда консерваторы во главе с канцлером от ХДС К.-Г. Кизингером возглавили правящую коалицию с социал-демократами.

Переговоры между ХДС/ХСС и СДПГ продлились около трёх недель. Ни одна из партий не хотела уступать пост канцлера. Лишь к середине ноября 2005 г. удалось достигнуть соглашения. Новым федеральным канцлером Германии впервые за всю её историю стала женщина - лидер христианских демократов А. Меркель. В обмен на эту уступку социал-демократы получили 8 из 15 министерских постов, в т.ч. иностранных дел, финансов, юстиции, труда, охраны окружающей среды, здравоохранения, транспорта и экономического сотрудничества и развития. В ве́дение ХДС/ХСС отошли министерства обороны, внутренних дел, безопасности, экономики и технологий, семьи, образования, а также сельского хозяйства.

Партии заключили «коалиционный договор», который определил основные направления работы правительства на последующие четыре года: «Германия находится перед большими вызовами. Безработица, государственный долг, демографические изменения и влияние глобализации требуют огромных политических усилий, чтобы обеспечить сегодняшним и будущим поколениям достойную жизнь. ХДС, ХСС и СДПГ берут на себя решение этих задач» ${ }^{13}$. Оздоровление государственных финансов и борьба с безработицей стали главными темами коалиционного соглашения.

\footnotetext{
${ }^{12}$ И Шрёдер и Меркель считают себя победителями. 19.09.2005. URL: http:// news.nbc.com.ua/NEWSactionISarticleANDtext_idIS6151ANDdateIS19.9.2005. html. (дата обращения: 08.08.2019).

${ }_{13}$ «Gemeinsam für Deutschland. Mit Mut und Menschlichkeit» Koalitionsvertrag von CDU, CSU und SPD. URL: http://library.fes.de/pdf-files/bibliothek/downl/ 05 1111 koalitionsvertrag langfassung navigierbar-1.pdf. (дата обращения: 24.12.2006).
} 
Спад производства, старение населения привели к сокращению численности работающих налогоплательщиков, на которых лежит основная нагрузка по уплате социальных взносов. Резкий приток иммигрантов, к которому прибегло германское правительство ранее, оказался противоречивой мерой, поскольку многие из приезжающих в страну не смогли интегрироваться в немецкое общество и пополнили ряды безработных, живущих за счёт государственных дотаций. «Настоящая проблема состоит в том, что уменьшается финансовая основа нашей системы социального обеспечения, поскольку исчезают нормальные условия занятости, - констатировала А. Меркель после своей победы. - Нам придётся заниматься тем, чтобы вновь сделать занятость привлекательной в классическом смысле. Мы должны устранить зависимость между стоимостью труда и социальными затратами» ${ }^{14}$.

Следует отметить, что новое правительство довольно быстро добилось успеха в этом направлении. Уже через год уровень безработицы в Германии оказался ниже критической отметки в 10,8\% (2005 г.) и составил в декабре 2006 г. 9,6\%. По данным федерального агентства по работе, количество немецких безработных сократилось в 2006 г. на 374 тыс. человек, в 2007 г. ещё на 200 тыс. $^{15}$

Оздоровление экономики и социального обеспечения подразумевает не только создание новых рабочих мест, но и серьёзное реформирование пенсионной системы и системы здравоохранения с целью снизить государственные затраты, а также совершенствовать налоговое и трудовое законодательства Германии. Именно по этому пути была вынуждена пойти большая коалиция. Правящие партии отчётливо понимали, что меры, направленные на уменьшение государственного участия, и, следовательно, на сокращение государственных гарантий, могут вызывать страх и недовольство у населения, привыкшего за многие годы жить в условиях социального государства и не желающего

14 A. Merkel. Ich habe Antworten. Spiegel-Gespräch; Der Spiegel, №2, 2006, 09.01.2006. URL: http://service.spiegel.de/digas/servlet/find (дата обращения: 15.09.2006).

15 Dt. Arbeitsmarkt 2007. Prognose: weniger Arbeitslose! URL: http://www.vitalbasis.de/nebenjobs/arbeitmarkt.php (дата обращения: 19.12.2007). 
менять сложившуюся в течение десятилетий социальную систему. Опасение растерять популярность и проиграть следующие выборы из-за необходимости проводить глубокие реформы привело к серьёзным спорам внутри коалиции. Поэтому А. Меркель выступила за «политику малых шагов» и призвала своих коллег по коалиции чаще говорить «да, но», вместо употребляемого ими «нет, но» ${ }^{16}$. Тактика пошагового достижения цели превратилась со временем в визитную карточку А. Меркель и стала одним из основных инструментов управления.

Наиболее острые дискуссии между правящими партиями разгорелись по вопросам здравоохранения, пенсионного обеспечения и введения минимальной оплаты труда. И хотя 2 февраля 2007 г. бундестаг одобрил проект реформы по здравоохранению (378 депутатов проголосовали «за», 206 - «против», а 8 воздержались), количество сторонников ХДС/ХСС и СДПГ за первый период работы большой коалиции существенно снизилось ${ }^{17}$.

Больше всего пострадал блок ХДС/ХСС. Доля избирателей, которые воспринимали этот союз как расколотый, увеличилась с $32 \%$ в 2005 г. до 52\% в 2006 г., и только $21 \%$ продолжали верить в его сплочённость. Впечатление, что среди сестринских партий нет единства, особенно усилилось после их споров относительно реформы здравоохранения. Немецкие избиратели усомнились в способности ХДС/ХСС завоевать в обозримом будущем их симпатии: 45\% немецких граждан высказали мнение, что в дальнейшем союз консерваторов продолжит терять позиции ${ }^{18}$. Таким образом, популярность христианских демократов среди населения в 2006 г. упала до уровня 1998 г., когда они были вынуждены уступить власть красно-зелёной коалиции.

Не удалось завоевать доверие избирателей и их партнёру по коалиции - СДПГ, у которой также были серьёзные разногласия по вопросам упомянутой реформы. Согласно исследованиям, после года пребывания в большой коалиции социал-демократы

${ }^{16}$ Kleinstkarierte Spielchen, 09.10.2006, Parteitag, 26.11.06. URL: http://www. faz.net. (дата обращения: 12.02.2006).

${ }^{17}$ Pressemietteilung. 02.02.2006, Bundesministerium für Gesundheit. URL: http:// www.die-gesundheitsreform.de/presse/pressemitteilung/dokumente/2007_1/pm 2007-02-02-013.html?param=reform2006 (дата обращения: 12.02.2006).

${ }^{18}$ Ibid. 
уступили свои позиции «Союзу 90/Зелёным» в вопросах окружающей среды, новых источников энергии и качества продуктов питания. В целом СДПГ критиковали по меньшему количеству направлений, чем ХДС/ХСС, но доля её сторонников снизилась.

Улучшить рейтинги удалось только двум партиям - СвДП и «Левой»: около 39\% населения ожидало, что на следующих выборах они сумеют повысить результаты. Рост популярности оппозиционных партий, включая «зелёных», был связан не столько с привлекательностью самих партий, сколько с разочарованием избирателей в способности большой коалиции вывести страну из кризиса и провести реформы. По истечении первого периода совместного правления ХДС/ХСС и СДПГ у населения сложилось впечатление, будто партии «связали себя по рукам и ногам», создав правительственную коалицию, и едва ли смогут добиться провозглашённых в программе целей ${ }^{19}$.

Утрата доверия избирателей в этот период - тенденция, характерная для всех немецких партий, и обозначилась она задолго до 2005 г. Создание правительственной коалиции из двух народных партий - традиционных соперников - породило сомнения у избирателей в том, что, их выбор влияет на дальнейшее развитие государства и определяет будущие решения правительства. Помимо привычного разделения партийно-политического ландшафта на правый и левый фланги, на электоральное поведение всё большее влияние стал оказывать фактор нахождения партии у власти. ХДС/ХСС и СДПГ оказались для избирателя как никогда похожими друг на друга политическими силами, основными чертами которых стал не только опыт управления государством, но и его обратная сторона - неспособность решить актуальные задачи.

Образы народных партий всё больше сближались в сознании населения как несущие совместную ответственность за социально-экономическое развитие Германии. Их популярность снижалась. Соответственно, ХДС/ХСС и СДПГ предприняли попытки конкретизировать свои политические программы и стать тем самым более понятными и привлекательными для избирателей. В свою очередь малые партии не стали подыгрывать од-

${ }^{19}$ Ibid. 
ной из ведущих политических сил, а предпочли извлечь собственные дивиденды за счёт критики правительственной коалиции.

В сентябре 2007 г. четыре ведущих политика «Молодёжного союза» ${ }^{20} \mathrm{XДС/ХСС} \mathrm{составили} \mathrm{документ} \mathrm{«Современный} \mathrm{бюр-}$ герский консерватизм. Почему Союз должен снова обратиться к своим корням» ${ }^{21}$, в котором упрекнули соратников по партии в недостаточно консервативной политике и высказали опасение, что ХДС/ХСС может потерять себя в большой коалиции. Авторы документа ${ }^{22}$ посчитали, что без чётко обозначенного консервативного курса блоку ХДС/ХСС не удастся завоевать буржуазно-консервативное большинство Германии на выборах в 2009 г. Для достижения этой цели ему «по-прежнему необходимо оставаться политической родиной для патриотов своей страны, для убеждённых христиан и консерваторов по духу». По их мнению, ответом на изменения, происходящие в мире и обществе, могут стать такие традиционные «немецкие добродетели, как честность, надёжность, дисциплина, прилежность, верность и порядочность». Учитывая распространившиеся в Германии к тому времени левые настроения, буржуазная альтернатива должна стать более видимой и понятной для избирателей: «Наша политика должна быть узнаваемой. Ей необходим почерк, который не перепутаешь с другими. Мы не должны в политической жизни идти только на компромиссы» ${ }^{23}$.

Одной из основ такого консервативного курса, по мнению молодых политиков, могли бы стать меры по ограничению иммиграции. «Мнимый модернизм и релятивизм уже привели к потере общего смысла. Ещё не рождённая жизнь, так же, как и

20 «unge Union».

${ }^{21}$ Moderner Bürglicher Konservatismus. Warum die Union wieder mehr an ihrer Wurzeln denken muss. Dokumentation: Konzeptpapier der Union. URL: http:// www.faz.net. (дата обращения: 21.12.2007).

${ }^{22}$ Авторы документа: Стефан Маппус (председатель фракции ХДС в БаденВюртемберге), Маркус Зёдер (генеральный секретарь ХСС), Филипп Мисфельдер (председатель «Молодёжного союза») и Хендрик Вюст (генеральный секретарь ХДС в Северном Рейн-Вестфалии).

${ }^{23}$ Der Union fehlt es an Konservatismus. URL: https://www.faz.net/aktuell/ politik/inland/der-union-fehlt-es-an-konservatismus-1462565.html (дата обращения: 21.12.2007). 
жизнь старых людей, нуждается в защите, и христианские символы должны сохранить своё место в обществе». Немецкая культура обязана оставаться «ведущей», поэтому главной предпосылкой для интеграции иностранцев в немецкое общество должно стать осознание его ценностей, ибо «толерантность можно требовать только при безоговорочном признании других». Не каждая модель общества заслуживает, даже в рамках плюрализма, одинакового развития. «Интеграционная способность нашей страны имеет свои границы. Ни одно общество не может принимать людей другой культуры в бесчисленном количестве. Поэтому мы отклоняем переселение, которое отягощает нашу социальную систему», - говорится в документе ${ }^{24}$.

Другой важной составляющей консервативной политики ХДС/ХСС должно стать обращение к традиционному институту общества - семье. Молодые лидеры выступили за поддержку политики канцлера А. Меркель по созданию яслей. По мнению некоторых из них, деньги на воспитание должны получать и те родители, чьи дети не будут посещать ясли: «Союз должен сделать предложение всем семьям. Семья должна сама принимать за себя решения, а не государство» ${ }^{25}$.

Наиболее сильной критике в документе подвергся курс ХДС/ХСС в области защиты окружающей среды: «Идеологические шаблоны 1970-х гг. не продвинули нас дальше. Изменение климата недостаточно только признать, необходимо стараться задержать его. Помочь этому может строительство атомных электростанций, однако они не должны заменить собой полностью газ и уголь. Если союз пойдёт по такому пути, то совершит “фатальную ошибку”». Авторы документа раскритиковали намерения министра сельского хозяйства - представителя ХСС $\mathrm{X}$. Зеехофера - разрешить крестьянам разводить генетически изменённые растения.

Молодые консерваторы выступили против их восприятия как реакционеров. Предложенная ими политика должна быть понятна и близка не только элите общества, но и, прежде всего,

\footnotetext{
${ }^{24}$ Wulf Schmiese. Konservativ im Herzen - progressiv im Geist. F.A.Z., 06.09. 2007, №207. S. 4.

${ }^{25}$ Ibid.
} 
обычным его представителям: водителям, медсёстрам, рабочим, полицейским, предпринимателям. «Упорные, но не упёртые, открытые, но осторожные, свободные от предрассудков, но уважающие ценности. Консервативные в сердце - прогрессивные по духу», - такими они представили себя соратникам по партии ${ }^{26}$.

Инициативы четвёрки не осталась не замеченными. На партийном конгрессе в г. Ханау осенью 2007 г. председатель ХДС, канцлер А. Меркель похвалила своих молодых коллег: «Такие добродетели, как прилежность и честность не являются старомодными понятиями. Мы помним нашу культуру, мы привержены нашему отечеству» ${ }^{27}$. Однако к большим программным изменениям эти призывы не привели.

Сентябрь 2007 г. оказался непростым и для СДПГ. В партии разгорелись дебаты о целесообразности продолжения прежнего курса - «Повестки дня 2010», принятого красно-зелёным правительством. Поводом для спора стала книга «На высоте времени - социальная демократия и прогресс в 21 веке», которую представили общественности 3 сентября 2007 г. три ведущих политика СДПГ - федеральный министр иностранных дел Ф.-В. Штайнмайер, федеральный министр финансов П. Штайнбрюк и бывший председатель партии М. Платцек ${ }^{28}$. В книге все трое высказались за продолжение реформ «Повестки дня 2010», которые начали проводить бывший бундесканцлер Г. Шрёдер и П. Харц. «Семь лет правления красно-зелёной коалиции не были потерянным временем. Вклад Г. Шрёдера стал решающим для того, чтобы поднять СДПГ в первом десятилетии этого столетия на вершину времени», - заявил баварскому радиовещанию министр финансов Германии П. Штайнбрюк ${ }^{29}$.

Защитникам реформ пришлось выслушать немало критики в свой адрес со стороны других членов партии. Председатель «Молодых социалистов» Б. Бёнинг отговаривал их от новых

\footnotetext{
26 Ibid.

27 Ibid.

${ }^{28}$ M. Platzeck, F.-W. Steinmeier, P. Steinbrück (Hg). Auf der Höhe der Zeit Soziale Demokratie und Fortschritt im 21. Jahrhundert. Vorwärts Buch, 2007.

29 Stephan Loewenstein. Programmstreit. SPD uneins über Agenda 2010. am 03.09.2007. URL: http://www.faz.net (дата обращения: 21.12.2007).
} 
опасных для СДПГ программных дискуссий: по его мнению, авторы книги «не дают ясных ответов на вопрос, как должна выглядеть правильная экономическая политика во времена глобализации» ${ }^{30}$. Не соответствовала эта позиция и настроениям левого крыла партии, представительница которого А. Налес предостерегла коллег от провозглашения социал-демократами своей целью «социального государства консерваторов» 31 .

Нервозности в обстановку добавил тот факт, что присутствовавший на презентации книги председатель партии К. Бек не выступил с собственным докладом, в котором бы выразил своё отношение к дальнейшему курсу СДПГ. Пресса заговорила о слишком слабом руководстве в партии. В результате К. Бек был вынужден прокомментировать ситуацию на заседании Совета СДПГ и выступить против того, что «некоторые политики за кулисами высказывают сомнения в его способности руководить». Он призвал «перестать сводить счёты» и заявил, что не позволит, чтобы «призывы, за которыми никто не стоит» мешали подготовительной работе СДПГ в преддверии октябрьского съезда, на котором 28 октября 2007 г. абсолютным большинством («против» было только два голоса) была принята новая «Гамбургская программа».

Своей главной целью социал-демократы провозгласили «демократический социализм», к основным ценностям которого относятся свобода, справедливость и солидарность. «Мы стремимся к мирному и справедливому мировому устройству, - говорится в преамбуле документа, - Мы выступаем за силу права, чтобы победить право сильных. Социальная Европа должна стать нашим ответом на глобализацию. Мы развиваем «предусматривающее социальное государство», которое победит бедность, откроет для людей равные шансы самим определять свою жизнь, обеспечит справедливое распределение и застрахует крупные жизненные риски. Мы выступаем за связь поколений и равные шансы для мужчин и женщин. Мы предлагаем нашу поддержку семьям, нашу солидарность слабым. Мы выступаем за здоровый образ жизни и хорошее образование» ${ }^{32}$.

\footnotetext{
30 Ibid.

31 Ibid.

32 Hamburger Programm. Grundsatzprogramm der Sozialdemokratischen Partei
} 
Способствовать достижению заявленных целей, по замыслу социал-демократов, должна была «достойная работа для всех». «Мы не отказываемся от цели полной занятости, несмотря на возросшую за последние десятилетия безработицу в Германии», - говорится в программе. «Мы знаём, что эту цель достигнуть непросто. Глобализация изменила рынок труда. Поэтому полная занятость не означает для нас сегодня безоговорочную гарантию того, что каждый будет работать в одной и той же фирме всю жизнь». Полная занятость сейчас, по мнению СДПГ, это когда у каждого человека есть шансы получить достойную работу и соответствующую ей квалификацию. Необходимая квалификация, дальнейшее образование, воспитание детей, работа на дому, общественная и политическая работа должны получить признание и поэтому быть застрахованы общественной солидарностью $^{33}$. Этому должны способствовать современное трудовое законодательство, благоприятные условия работы, защита от увольнений, совместное участие в управлении и тарифная автономия. Для того чтобы больше людей смогли получить работу, в программе предусматривалось сокращение рабочего времени, которое сделает политику в области занятости более гибкой.

По мнению бывшего вице-канцлера и федерального министра по труду Ф. Мюнтеферинга, достойная работа подразумевает и соответствующую оплату. Поэтому во время своего выступления на партийном съезде в Гамбурге он потребовал ввести узаконенный минимум оплаты труда: «Минимальная зарплата - это не социальная романтическая идея, а необходимая политическая основа, очень важная для сплочённости общества» ${ }^{34}$.

Другая важная предпосылка для развития Германии, по мнению социал-демократов, - успешная интеграция переселенцев в немецкое общество. СДПГ не исключила возможность предоставления двойного гражданства. Тем, кто ещё не получил немецкое гражданство, но уже долгое время живёт в Германии, социал-демократы были готовы предоставить право участво-

Deutschlands. Beschlossen auf dem Hamburger Bundesparteitag der SPD am 28. Oktober 2007. S. 3.

${ }^{33}$ Ibid. S. 29-30.

34 Müntefering: Mindestlohn keine sozialromantische Idee. URL: http://parteitag. spd.de (дата обращения: 15.02.2008). 
вать в коммунальных выборах, даже если они выходцы из государств, не принадлежащих к Европейскому союзу.

Партийный съезд в Гамбурге, без сомнения, можно считать историческим, новой отправной точкой для социал-демократического движения. Он показал, что социал-демократы не только настроены на серьёзную предвыборную борьбу, предстоявшую в 2009 г., но и готовы предложить избирателям свой путь развития Германии - «демократический социализм». Многие, принятые на этом съезде программные положения, СДПГ использовала в дальнейшем и сумела включить в коалиционные соглашения с ХДС/ХСС.

Такое «полевение» курса СДПГ не преминули отметить все политические силы Германии. «Левая» и «Союз 90/Зелёные» подчеркнули свою солидарность с решениями партийной конференции социал-демократов. По мнению председателя либеральной партии Г. Вестервелле, провозгласив своей целью «демократический социализм», социал-демократы очень отдалились от СвДП, практически перечеркнув возможность союза этих партий в будущем ${ }^{35}$. Кроме того, Гамбургская программа СДПГ поставила под вопрос существование самой большой коалиции.

Критически, но не без вздоха облегчения, оценили новую программу социал-демократов и представители союза ХДС/ ХСС. Бундесканцлер А. Меркель охарактеризовала новую стратегию СДПГ следующим образом: «Мы не нуждаемся в воспоминаниях о социализме, как социал-демократы. От социализма мы достаточно натерпелись в ГДР». Генеральный секретарь ХДС Р. Пофалла констатировал, что, сделав уклон влево, социал-демократы тем самым освободили для ХДС место «народной партии середины» ${ }^{36}$.

Именно понятие «народной партии середины» стало центральным в новой программе ХДС, которую христианские демократы приняли вслед за СДПГ в декабре 2007 г. в Ганновере, и которая была призвана подчеркнуть дистанцию для избирателей между двумя правящими партиями.

\footnotetext{
${ }^{35}$ Pressemitteilung vom 07.11.2007, Westerwelle-Interview für die «Freie Presse». URL: http://www.fdp-kleinmachnow.de (дата обращения: 21.12.2007).

${ }^{36}$ Zurück zum Sozialismus, 29.10.2007. URL: http://www.faz.net (дата обращения: 21.12.2007).
} 
«ХДС - народная партия середины», - говорится в преамбуле документа, - «в ней до сих пор сильны политические течения, которые предопределили её возникновение после 1945г.: христианско-социальные, либеральные и консервативные» ${ }^{37}$. По мнению христианских демократов, германское государство должно стать «обществом шансов», в котором граждане будут чувствовать себя свободными и защищёнными. Главная задача христианско-демократической политики - «развитие собственной ответственности граждан». Там, где этого окажется недостаточно, государство готово предоставить помощь ${ }^{38}$.

Чтобы нести ответственность, человек должен развивать собственные силы и активность. Именно в семье происходит многостороннее развитие личности со всеми её способностями. В семье человек впервые познаёт разницу между свободой и ответственностью. ХДС намерен усилить институт семьи и брака как фундамент общества, и выступает за дружественную по отношению к семье и детям политику, за взаимодействие поколений. Поэтому одним из основных направлений христианско-демократической политики должно стать создание возможностей для совмещения семьи и работы. «Мы хотим, чтобы те из нас, кто берёт на себя ответственность и идёт работать, получили широкую поддержку всего общества и были лучше включены в систему страхования и налоговую систему», - говорится в программе $^{39}$.

Основой экономической политики христианских демократов остаётся социальное рыночное хозяйство, которое позволяет гражданам участвовать в конкуренции и тем самым выполняет важные функции не только для рынка.

ХДС требует равных стартовых возможностей для получения образования и работы: «Мы хотим создать равные шансы, но не обещаем одинаковых результатов». «Справедливость требует и соответствующей нагрузки, - отмечается в документе, -

37 Das Grundsatzprogramm der CDU «Freiheit und Sicherhaeit. Grundsätze für Deutschland» beschlossen vom 21 Parteitag im Hannover 3-4 Dezember 2007. S. 2; URL: http://www.grundsatzprogramm.cdu.de/doc/071203-beschluss-grundsatzpro gramm-5-navigierbar.pdf (дата обращения: 21.12.2007).

${ }^{38}$ Ibid. S. 11.

${ }^{39}$ Ibid. S. 12. 
поэтому вклад сильных для нашего общества должен быть более ощутимым, чем слабых» ${ }^{40}$.

К основным целям политики ХДС относится обеспечение внутренней безопасности, одной из составляющих которой является культурная идентичность общества. Поэтому интеграция переселенцев в немецкое общество должна происходить на базе немецкой культуры. Поскольку перед лицом мировых угроз внутреннюю безопасность едва ли можно отделить от внешней, то ХДС выступил за применение сил бундесвера внутри страны в случаях особой опасности ${ }^{41}$.

Таким образом, к выборам в бундестаг 2009 г. народные партии ХДС/ХСС и СДПГ подошли с новыми программами, желанием идти разными дорогами и сомнением избирателей в эффективности их союза. В 2005-2009 гг. большую коалицию в обществе воспринимали скорее как исключение из правил, вынужденную необходимость, чем как новую тенденцию развития партийно-политической системы объединённой Германии.

\section{3. ВЫБОРЫ В БУНДЕСТАГ 2009 г. И ПРАВЛЕНИЕ ЧЁРНО-ЖЁЛТОЙ КОАЛИЦИИ}

С наибольшими потерями на выборах в бундестаг 2009 г. столкнулись социал-демократы. Они потерпели горькое поражение, набрав лишь 23\% голосов. Однако и союз ХДС/ХСС во главе с канцлером А. Меркель показал второй худший результат в послевоенных выборах - 33,8\% ${ }^{42}$. Никогда ещё с 1949 г. - года образования Федеративной Республики Германия - явка на выборы не была столь низкой (70,8\%). Если в 1949 г. ХДС/ХСС и СДПГ поддерживало 60,3\% населения ФРГ, в 1976 - 91,2\%, в 2005 - 69\%, то в 2009 - лишь 56,8\%. За период 1995-2009 гг. уровень доверия населения к народным партиям, согласно исследованиям, снизился с 41 до $17 \%{ }^{43}$.

${ }^{40}$ Ibid. S. 10-11.

${ }^{41}$ Ibid. S. 21.

Материал данной главы первоначально был опубликован в: Тимошенкова Е.П. Партийно-политическое развитие ФРГ - шансы и риски чёрно-жёлтой коалиции. Германия. 2010. Под ред. Белова В.Б. М., ИЕ РАН, 2011. С. 10-33. 42 В 1949 г. они набрали $31 \%$ голосов.

${ }^{43}$ Viola Neu. Bundestagswahl in Deutschland am 27. September 2009. Wahlanaly- 
Основной причиной поражения СДПГ стало сомнение избирателей в том, что во власти она будет претворять в жизнь свои предвыборные обещания и ориентироваться на социальную справедливость. Разочарованию способствовал довольно длительный с 1998 г. курс, противоречащий основным ценностям социал-демократии, прежде всего, идее социальной справедливости. С тех пор как социал-демократическая партия при Г. Шрёдере начала привлекать новые группы избирателей так называемой «середины» общества, её ярко выраженный «социалистический» уклон начал стираться. Программа «Повестка дня 2010» и социальный пакет «Харц IV» предусматривали облегчение условий увольнения и найма работников, сокращение пособия по безработице и времени его выплаты; приватизацию железной дороги; рост налога на добавочную стоимость, ориентацию на интересы крупного бизнеса. Все эти и другие меры противоречили традиционным ценностям социал-демократии. Участие СДПГ в большой коалиции с христианскими демократами ещё больше увеличило количество скептиков, сомневающихся в способности партии отстаивать социалистические идеалы и интересы простых людей. Для многих согласие СДПГ на повышение возраста выхода на пенсию до 67 лет стало вторым изданием непопулярных мер «Харц IV». СДПГ оказалась в плену обстоятельств: ради спасения благосостояния Германии она была вынуждена проводить антисоциальную политику, не характерную для неё, тем самым нарушив одно из главных условий её поддержки избирателями и сохранения политического баланса. Вместе с тем выбор в пользу непопулярных реформ, который стоил партии падения рейтинга, в значительной степени способствовал укреплению немецкой экономики и решению её наиболее острых и тяжёлых проблем. В итоге Германия оказалась лучше подготовленной к мировому экономическому кризису, чем другие страны.

Однако у общества сложилось впечатление, что основные решения в коалиции принимал союз ХДС/ХCC, а не СДПГ. И главная заслуга в этом принадлежит лидеру христианских демо-

se. Berlin, Dezember 2009. Onlinepublikation. Herausgegeben von der KonradAdenauer-Stiftung. 
кратов и федеральному канцлеру А. Меркель, которая сумела за четыре года пребывания у власти представить общие успехи правительства как достижения своей партии. За время участия в большой коалиции СДПГ не удалось сформировать свой чёткий политический курс. Даже во время предвыборной кампании её лидеры не пошли на открытый разрыв со своими бывшими партнёрами, так и не сумев предложить избирателям тему, которая смогла бы стать альтернативой политике А. Меркель.

Кандидат в канцлеры от СДПГ Ф.-В. Штайнмайер, не отличаясь политической решимостью и яркой харизмой, оказался для избирателя противоречивой фигурой. С одной стороны, он был вице-канцлером, министром иностранных дел, вторым человеком в государстве, с другой - выдвиженцем Г. Шрёдера, соавтором его непопулярных реформ, повредивших имиджу СДПГ. Кроме того, у избирателя сложилось впечатление, что Ф.-В. Штайнмайер стал кандидатом на пост канцлера случайно, благодаря стечению обстоятельств и частым перестановкам в руководстве партии. Вплоть до отставки К. Бека, председателя СДПГ, не было ясно, кто именно поведёт партию на выборы.

Была совершена и тактическая ошибка - руководство СДПГ не организовало серьёзный диалог с членами партии о шансах и рисках создания возможной коалиции с партией «Левая». Из высказываний лидеров социал-демократов практически до последнего дня нельзя было понять, с кем они будут вступать в партнёрство в случае победы. Между тем христианские демократы не скрывали своих коалиционных предпочтений и сделали ставку на союз со Свободной демократической партией, которая завоевала рекордные для неё 14,6\% голосов (в сравнении с 9,8\% в 2005 г.), среди прочего пообещав населению существенно сократить налоги.

Другим дополнительным фактором, способствующим победе ХДС/ХСС, стал так называемый «бонус канцлера». Накануне выборов А. Меркель поддерживало 78\% населения, среди них $50 \%$ традиционных сторонников социал-демократов. Таким образом, большинство избирателей предпочли отдать свои голоса не СДПГ, попытавшейся в условиях кризиса стать более либеральной, а партиям, которые традиционно и ранее придержива- 
лись подобной политики - союзу ХДС/ХСС и СвДП. По мнению немцев, они оказались более компетентными в решении экономических проблем.

ХДС/ХСС и СвДП объявили создание чёрно-жёлтой коалиции как «наиболее желательный» для них вариант исхода выборов. Тем не менее, с самого начала их представления о будущей политике Германии по многим вопросам отличались. Так, например, СвДП обещала своим избирателям значительно сократить налоги и создать более простую налоговую систему, которая базировалась бы на трёх тарифах $(10,25,30 \%)$. Союз ХДС/ ХСС был против подобных радикальных предложений, считая, что в условиях экономического кризиса государство не может позволить себе значительные налоговые послабления. Не нравились христианским демократам и призывы СвДП упростить наём и увольнение сотрудников. Либералы надеялись также убедить своих партнёров отменить уже введённые для отдельных отраслей минимумы по зарплате. Напротив, союз ХДС/ХСС считал необходимым поддержать трудящихся в низкооплачиваемых секторах, гарантировав им «минимальный доход», в том числе за счёт государства. Характерно, что в итоге партнёры по коалиции выступили против введения в Германии единой минимальной оплаты труда.

Свободные демократы планировали «радикальную перестройку социальной системы» и введение «единого денежного пособия» в размере 662 евро в месяц, которое заменило бы все социальные выплаты. Они отклонили принятое ХДС/ХСС совместно с СДПГ повышение возраста выхода на пенсию до 67 лет и введение гарантированных пенсионных выплат с 2010 г. Вместо этого СвДП предложило систему более гибкого выхода на пенсию по выбору, оставляя вопрос о сокращении пенсионного порога открытым. В сфере здравоохранения свободные демократы выступили за отмену Фонда больничных касс и создание «системы премий», основанной на выплате «единого взноса» независимо от уровня заработной платы. Принципиальных разногласий между победителями выборов не возникло лишь по энергетической и внешней политике.

Таким образом, коалиционное соглашение изначально со- 
держало большой конфликтный потенциал. Компромиссные формулировки, к которым в результате переговоров пришли ХДС/ХСС и СвДП, во многом лишь отодвинули решение спорных вопросов на более поздний срок, превратившись тем самым в мину замедленного действия и серьёзный дестабилизирующий фактор для взаимодействия партий в будущем.

В истории ФРГ есть множество примеров успешного сотрудничества ХДС/ХСС и СвДП, но коалиция 2009 г. оказалась, на наш взгляд, исключением, что привело в итоге к фатальным последствиям для либералов. Отсутствие единой точки зрения между партнёрами практически по всем ключевым вопросам коалиционного соглашения, популизм, напряжённые отношения между лидерами партий А. Меркель и Г. Вестервелле (а затем Ф. Рёслером) не только запутали избирателей в понимании курса чёрно-жёлтого правительства, но и привели к кризису правящей коалиции. Следствием стала серия мощных поражений ХДС и СвДП на земельных выборах, начиная с Севеного Рейн-Вестфалии. Тогда, 9 мая 2010 г., христианские демократы набрали всего на $1 \%$ больше, чем социал-демократы, получив равное количество мест в парламенте. СДПГ отказалась от варианта большой коалиции и самостоятельно сформировала красно-зелёное правительство меньшинства с опорой на «левых», которые впервые вошли в ландтаг г. Дюссельдорфа. Именно после этого правящие партии утратили большинство голосов в палате земель - бундесрате, которое необходимо для беспрепятственного утверждения законов, принимаемых в бундестаге, и, следовательно, для реализации правительственного курса. На этом череда поражений для христианских демократов и либералов не закончилась.

\section{4. ЗНАЧЕНИЕ ЗЕМЕЛЬНЫХ ВЫБОРОВ 2011 r. ДЛЯ ПОЛИТИЧЕСКИХ ПАРТИЙ ФРГ}

2011 г. стал для Федеративной Республики Германия годом выборов в ландтаги: семь раз немецкие партии боролись за го-

Материал данной главы первоначально был опубликован в: Тимошенкова Е.П. «Особенности партийно-политического развития ФРГ», Германия. 2011. Под ред. Белова В.Б. М., 2012. С. 53-77. 
лоса избирателей и места в земельных парламентах. Свой выбор сделали жители Гамбурга (20 февраля), федеральных земель Саксонии-Ангальт (20 марта), Баден-Вюртемберга (27 марта), Рейнланд-Пфальца (27 марта), Бремена (22 мая), МекленбургПередней Померании (4 сентября) и Берлина (18 сентября).

Сочиал-демократическая партия Германии ${ }^{44}$. Главным итогом для СДПГ после её катастрофического поражения на федеральных выборах 2009 г. можно считать тот факт, что она вновь начала побеждать. Получив неожиданно абсолютное большинство голосов в Гамбурге $(48,4 \%)$, СДПГ единолично сформировала правительство во главе с бургомистром Олафом Шольцем, которому удалось увеличить показатели по сравнению с прошлыми выборами на 10\% и продемонстрировать лучший для партии результат с 1982 г. В Саконии-Ангальт партия оказалась лишь на третьем месте, однако осталась в правительстве в коалиции с ХДС. В Баден-Вюртемберге социал-демократы стали младшим партнёром «зелёных», а в Рейнланд-Пфальце, несмотря на значительные потери $(-9,9 \%)$, сумели остаться ведущей силой, сформировав красно-зелёный Кабинет. Немного улучшив свой предыдущий результат в Бремене (с 36,7 до 38,6\%), СДПГ не стала менять союзника по коалиции и продолжила править городом вместе с партией «Союз 90/Зелёные». В МекленбургПередней Померании она была вынуждена заключить союз с ХДС. Эта же коалиция пришла на смену красно-красному правительству в Берлине, которое в третий раз подряд возглавил кандидат от СДПГ К. Воверайт, хотя ему не удалось получить прямой мандат от избирателей.

Таким образом, 2011 г. оказался для социал-демократов весьма результативным. Они вошли в правительства всех семи федеральных земель, в которых состоялись выборы, заключив коалиционные соглашения с «зелёными» и христианскими демократами.

Кроме того в декабре 2011 г. СДПГ приняла новую программу. Её ядром стало требование уменьшить государственный долг и одновременно увеличить инвестиции в образование. В

\footnotetext{
44 Здесь и далее для анализа результатов выборов используются данные, представленные на сайте «Избирательное право»: http://www.wahlrecht.de.
} 
программе была предложена новая налогово-финансовая концепция, зафиксировано требование законодательного введения минимальной оплаты труда в размере 8,5 евро в час, представлен новый проект страхования граждан (он должен был решить проблемы невысоких пенсий и заменить «трёх-классовую медицину»). Кроме того, СДПГ выступила за введение на федеральном уровне т.н. «Народного кодекса законов», состоящего из решений, принимаемых гражданами, что, по её мнению, должно было способствовать усилению прямой демократии ${ }^{45}$. Новая программа расширила влияние социал-демократов на формирование политического курса ФРГ. Результаты земельных выборов 2011 г. дали партии надежду на более высокие по сравнению с 2009 г. показатели в будущем.

Христианско-демократический союз. Для ХДС 2011 г. оказался не лучшим с точки зрения итогов земельных выборов и принёс большие разочарования. Значительную долю голосов Христианско-демократический союз потерял на выборах в Гамбурге, лишившись половины избирателей и сократив свой предыдущий результат с 42,6\% (2008 г.) до 21,9\%. Тем самым была подведена черта под первой в истории ФРГ чёрно-зелёной коалицией. В Бремене партия оказалась на третьем месте (20,4\%), пропустив вперёд «Союз 90/Зелёные». Хороший результат $(35,2 \%)$ она продемонстрировала на земельных выборах в Рейнланд-Пфальце. Однако её кандидату Юлии Клёкнер не хватило буквально $1 \%$, чтобы сместить социал-демократов $(35,7 \%)$, лидером которых был Курт Бек. Христианские демократы понесли некоторые потери в Саксонии-Ангальт. Тем не менее, им удалось остаться в этой земле ведущей политической силой $(32,5 \%)$ и сформировать правительство вместе с СДПГ. Невысокие показатели в Мекленбург-Передней Померании (23\%) не препятствовали продолжению большой коалиции, а результаты выборов в Берлине принесли ХДС 23\% голосов и позволили ей стать младшим партнёром СДПГ, которая отказалась от союза с «зелёными» из-за споров о строительстве автобана вокруг города.

Своё самое тяжёлое поражение ХДС потерпел 27 марта 2011

${ }^{45}$ Mitte-Links. URL: http://www.spd.de/aktuelles/Parteitag_2011/21962/20111206 _abschluss text.html (дата обращения 16.01.2012). 
г. в Баден-Вюртемберге - традиционной вотчине консерватизма. Впервые с 1953 г. христианские демократы не только не смогли возглавить правительство в этой земле, но и были вынуждены уйти в оппозицию, передав власть «Союзу 90/Зелёные» и СДПГ. Одной из главных причин поражения ХДС стал конфликт вокруг реконструкции вокзала в г. Штутгарте. Чрезвычайно дорогой проект, стоимость которого постоянно росла, достигнув в итоге 5,1 млрд евро, оказался крайне непопулярным среди горожан $^{46}$. В ситуацию оказалась замешана А. Меркель. Несмотря на явное недовольство граждан проектом «Штутгарт $21 »$, она отклонила требование оппозиции провести опрос населения, объяснив, что решение о реконструкции вокзала было принято законно. Более того, А. Меркель заявила, что «земельные выборы следующего года станут таким опросом граждан о будущем Баден-Вюртемберга, «Штутгарта 21» и многих других проектов» ${ }^{47}$. Тем самым она сама придала этой теме судьбоносное значение на выборах.

Такая жёсткая позиция А. Меркель и ХДС весьма показательна. С одной стороны, она заставляет задуматься о стиле управления канцлерин, которая сконцентрировала принятие решений на себе и делает это зачастую без оглядки не только на граждан, но и на партнёров по коалиции и оппозиционные партии. С другой стороны, наглядно демонстрирует, насколько велик в Германии разрыв между интересами простых людей и политическим классом, и как опасно для политиков игнорировать интересы избирателей.

Поражение ХДС в Баден-Вюртемберге многие эксперты сравнили с провалом СДПГ на выборах 2005 г. в Северном РейнВестфалии. Потеряв этот традиционный оплот социал-демократии, канцлер Г. Шрёдер решился тогда на роспуск бундестага и досрочные выборы, рассчитывая вновь завоевать доверие избирателей. В результате канцлером ФРГ стала А. Меркель. Однако канцлерин не стала следовать неудачному примеру своего

\footnotetext{
46 Сергей Сумленный. Историческое поражение Меркель. Expert Online. URL: http://expert.ru/2011/03/28/storicheskoe-porazhenie-merkel/ (дата обращения: 11.02.2012).

47 Merkel macht Stuttgart 21 um Wahlkampthema, vom 16.09.2010. URL: http://www.welt_online.de (дата обращения: 12.02.2012).
} 
предшественника и распускать парламент. Более того, она сумела извлечь главный урок из поражения партии - никогда не идти на открытый конфликт с обществом, что помогло ей обеспечить поддержку населения в будущем и подготовить ХДС к новым выборам.

Союз 90/Зелёные. Именно партию «Союз 90/Зелёные» можно рассматривать как партию - победителя выборного марафона 2011 г. Катастрофа атомного реактора «Фукусима» в Японии привела к тому, что вопрос о выходе из атомной энергетики для многих немецких избирателей стал решающим. Через неделю после «Фукусимы» популярность «зелёных» согласно опросам общественного мнения, резко возросла. Им удалось удвоить свой результат на земельных выборах в Саксонии-Ангальт - до $7,1 \%$ (3,6\% в 2006 г.) и спустя 13 лет вновь войти в парламент г. Магдебурга. В федеральной земле Рейнланд-Пфальц они получили рекордные для себя 15,4\% (в 2006 г. они не смогли преодолеть 5\%-ный барьер) и образовали правительственную коалицию с СДПГ.

Самый большой успех ожидал партию в земле Баден-Вюртемберг. Она получила $24,2 \%(+12,5 \%)$ и впервые смогла назначить своего премьер-министра Винфрида Кречманна, который возглавил зелёно-красный Кабинет. В Бремене «зелёные» стали вторыми $(22,5 \%)$, немного прибавили в Гамбурге и достигли своего лучшего результата в Берлине $(17,8 \%)$, рассчитывая на сотрудничество с СДПГ. Однако переговоры по созданию коалиции, как уже отмечалось выше, провалились. Не последнюю роль в этом, на наш взгляд, сыграли личные разногласия между К. Воверайтом и кандидатом от «зелёных» Ренатой Кюнаст, которая в ходе предвыборной кампании не раз заявляла, что готова войти в берлинский сенат только в качестве бургомистра, а не сенатора или тем более лидера оппозиции.

«Союз 90/Зелёные» стал единственной партией, которая не только улучшила свой результат на выборах, но и не потеряла голоса избирателей ни в одной из кампаний. Впервые за свою историю партия оказалась представлена в парламентах всех 16 федеральных земель. И, если в начале 2011 г. «зелёные» входили в состав лишь двух земельных правительств - в Бремене и 
Северном Рейн-Вестфалии, то к концу года к ним прибавились ещё две коалиции - в Баден-Вюртемберге и Рейнланд-Пфальце.

«Левая». Для «левых» итоги выборов 2011 г. оказались неоднозначными. В Гамбурге они повторили свой предыдущий результат $(6,4 \%)$ и во второй раз вошли в парламент на западе страны. В Саксонии-Ангальт они оказались вторыми после ХДС $(23,7 \%)$, но были вынуждены остаться в оппозиции. В федеральных землях Рейнланд-Пфальц и Баден-Вюртемберг войти в парламенты им не удалось. В Бремене, несмотря на потери, они получили пять мест. В Мекленбург-Передней Померании «левые» немного улучшили свой предыдущий результат, набрав 18,4\%. Тем не менее, они не смогли повторить успех 1994 и 1998 гг. - войти в состав правительств им не удалось. Согласно опросам общественного мнения во время выборов, около $70 \%$ респондентов считали, что партия «Левая» слишком разрознена для того, чтобы серьёзно заниматься политикой ${ }^{48}$.

Конфликты внутри партии и постоянные дебаты на федеральном уровне не способствовали, по мнению лидера берлинских «левых» Х. Вольфа, их победе в столице ${ }^{49}$. Набрав 11,7\% голосов, партия не смогла остаться в коалиции и была вынуждена перейти в оппозицию.

Свои проблемы «левые» попытались преодолеть на съезде партии, который проходил 21-23 октября 2011 г. в г. Эрфурте. Однако, хотя 96,9\% делегатов проголосовали за принятие программы, её трудно охарактеризовать как объединяющий партию документ. В нём чётко прослеживаются противоречия между двумя центрами «левых»-〈радикалами» и «реформаторами». С одной стороны, в программе говорится о необходимости перестроить политическую систему в стране, что подразумевает борьбу с капитализмом, огосударствление банков и крупных концернов, в первую очередь, энергетических. С другой стороны, в ней содержатся предложения, которые можно трактовать как требования реформировать социально-экономический уклад в сторону его «очеловечивания» - упразднение «Харц-IV»

48 Infratest dimap. URL: http://www.infratest-dimap.de/umfragen-analysen (дата обращения: 21.01.2012).

${ }^{49}$ Linke in Berlin. Wolf verzichtet offenbar auf Fraktionsführung. - am 19.09.2011. URL: www.spiegel-online.de (дата обращения: 21.01.2012). 
и выхода на пенсию в 67 лет, сокращение рабочего времени до 30 часов в неделю, поддержание системы социального страхования, введение минимальной оплаты труда и пенсий, которые должны составлять не менее $60 \%$ от среднегодового дохода. «Левые» по-прежнему выступают против использования сил немецкого бундесвера в военных операциях в других странах. Противоречивостью отличается отношение партии и к участию в управлении государством. Так, «Левая» решила не участвовать в правительственных коалициях на федеральном уровне, но не исключила такую возможность в землях ${ }^{50}$.

Таким образом, «левым» в 2011 г. не удалось войти ни в одно из земельных правительств. Более того, они были вынуждены покинуть единственную в Германии красно-красную коалицию в Берлине.

Свободная демократическая партия. Для СвДП 2011 г. стал годом беспрецедентного провала. Год начался для неё неплохо - в Гамбурге ей удалось получить рекордные для себя с 1978 г. $6,7 \%$ и вновь войти в парламент, но последовавшие выборы принесли горькие разочарования. В Баден-Вюртемберге она едва сумела преодолеть 5\%-ный барьер, сократив своё представительство в парламенте в 2 раза $(5,7 \%)$, и была вынуждена перейти в оппозицию. В Саксонии-Ангальт, Рейнланд-Пфальце, Бремене, Мекленбург-Передней Померании и в Берлине СвДП набрала рекордно низкое количество голосов и была вынуждена уйти из местных парламентов, поставив тем самым под вопрос свою надёжность для ХДС в качестве коалиционного партнёра на федеральном уровне.

Особенно сокрушительное поражение СвДП потерпела в столице Германии, набрав всего 1,8\% голосов, худший за всю историю партии результат. Одной из причин поражения либералов на этих выборах стала позиция её нового лидера Ф. Рёслера, которого либералы выбрали в мае 2011 г. вице-канцлером и председателем партии вместо Г. Вестервелле. Он выступил с резкой критикой политики правительственного кабинета по спасению еврозоны. Популистский демарш свободных демократов

\footnotetext{
${ }^{50}$ Programm der Partei Die Linke. ULR: http://www.die-linke.de/partei/dokumente /programmderparteidielinke (дата обращения: 21.01.2012).
} 
с предложением объявить о банкротстве Греции и поставить страну под внешнее финансовое управление, оттолкнул избирателей от партии, показал её неспособность к компромиссам со своим старшим партнёром по правящей коалиции и обострил и без того непростую ситуацию в ней. Примечательно, что около 30 тыс. традиционных сторонников СвДП предпочли проголосовать в этот раз за христианских демократов, что стало третьим поражением партии, за которое персонально ответственен Ф. Рёслер ${ }^{51}$.

Партия «Пирать»». Поражения СвДП стали ещё более заметными на фоне неожиданного успеха новой партии «Пираты», которая завоевала в Берлине рекордное количество голосов $(8,9 \%)$ и оказалась представлена в берлинском сенате 15 депутатами. До этой победы о партии было мало что известно. Последовательную и детальную программу, которая отвечала бы основным проблемам, стоящим перед жителями Берлина, «Пираты» представить не смогли. Их агитационная кампания была похожа скорее на политическую шутку и сильно отличалась от избирательных стратегий традиционных партий. Они не стояли под зонтиками на улицах, не раздавали ленточки и ручки, не дарили щедро предвыборные обещания. На их плакатах с чёрнобелыми фотографиями не были указаны имена кандидатов, тогда как персонификация выборов уже давно стала отличительной чертой современных избирательных кампаний. Их предвыборные лозунги, написанные некрупными шрифтом, не бросались в глаза, но отличались самоиронией и критичным подходом к происходящему ${ }^{52}$. Примером непрофессиональности и неподготовленности «Пиратов» к выборам стало интервью одного из представителей партии, который на вопрос, сколько долгов у Берлина, ответил, что несколько миллионов (реальные долги города составляли более 30 млрд евро).

Тем не менее, «Пираты» получили около 9\% голосов, что

${ }^{51}$ FDP nach der Berlin-Wahl. Euro-Skeptiker a.D. - von Severin Weiland, am 19. 09.2011. URL: http://www.spiegel.de/politik/deutschland/0,1518,787122,00.html (дата обращения: 21.01.2012).

${ }^{52}$ См., например: Mihael Borchsard, Sabine Stoze. Einzug der Piratenpartei in das Berliner Abgeordnetenhaus - eine Analyse des Wahlergebnisses. Parteimonitor Aktuell, Berlin, 21.09.2011. Konrad-Adenauer Stiftung. S. 8, 9. 
почти в четыре раза больше, чем было отдано Партии свободных демократов - партии с богатой историей и многолетним опытом управления страной. По результатам берлинских выборов, 54 тыс. сторонников традиционных партий проголосовали в этот день за партию под пиратским флагом: 4 тыс. голосов потерял ХДС, 6 тыс. - СвДП, 13 тыс. - «Левая», 14 тыс. - СДПГ и 17 тыс. - «Союз 90/Зелёные». Таким образом, больше всех от прихода в политику «Пиратов» пострадали партии левой ориентации, особенно «зелёные». «Пиратам» удалось мобилизовать и тех, кто обычно воздерживался от голосования: 23 тыс. абсентеистов и 22 тыс. «не принадлежащих к какой-либо группе» так же отдали на этих выборах предпочтение новой партии ${ }^{53}$.

Берлинский успех не стал политическим сюрпризом. Ранее в некоторых крупных городах Нижней Саксонии «Пираты» также показали неплохие результаты и сумели обойти партию «Левая» и свободных демократов в Брауншвейге, Ильзеде, Вольфсбурге и Ганновере ${ }^{54}$. На фоне потерь в лагере традиционных партий стремительный успех «Пиратов» заставил задуматься, в чём причины такого неожиданного взлёта, надолго ли эта партия пришла в политику и кто её потенциальный избиратель?

Согласно социологическим исследованиям, среднестатистические «пираты» - молодые люди от 18 до 34 лет, хорошо образованные, активные пользователи Интернета, в основном мужчины. Доля этой возрастной группы составила 42\% избирателей, 10\% пришлись на людей в возрасте 35-44 лет, 8\% на 4559-летних и 3\% - на тех, кому свыше 60 лет ${ }^{55}$. Социальный статус не являлся определяющим для избирателей фактором: доля безработных, отдавших свои голоса за «Пиратов», оказалась примерно такой же (13\%), как и тех, кто занимается частной индивидуальной деятельностью (14\%) ${ }^{56}$. «иратам» удалось сде-

\footnotetext{
${ }^{53}$ Ibid. S. 17.

54 Тарасова О., Берестов М. «Пираты» обречены на успех на выборах в Берлине. ICES. URL: http://www.elections-ices.org/russian/publica tions/region:euro pe/textid:12258 (дата обращения: 21.01.2012).

${ }^{55}$ Wähler nach Altersgruppen. Zahlen von infratest dimap. URL: http://wahlarchiv. tagesschau.de/wahlen/2011-09-18-LT-DE-BE/umfrage-alter.shtml (дата обращения: 21.01.2012).

56 Ibid.
} 
лать то, что плохо получается у народных партий - привлечь на свою сторону молодёжь - поколение, которое выросло на компьютерных технологиях, выражает культурный протест против устаревших форм политической деятельности традиционных партий.

«Пираты» не просто сделали ставку на Интернет - они попытались выработать новые формы взаимодействия с избирателями и их вовлечения в партийно-политическую жизнь. Для традиционных партий основу работы с массами составляют местные организации, а сайт в Интернете используется в основном для ознакомления с программой и основными новостями. В отличие от них, «Пираты» увидели в Интернете технологии средство прямого участия в процессе, возможность активно влиять на принятие решений в режиме «онлайн». Новая партия сознательно противопоставила себя партиям «старого образца» и потребовала большей транспарентности демократии в Германии.

Например, благодаря программе «Liquid Feedback» ${ }^{57}-$ специальному проекту «Пиратов» - у всех членов партии появилась возможность вносить свои предложения напрямую через сеть. Каждое мнение сразу становится известно другим участникам. При достижении кворума в $2 / 3$ голосов, оно выносится на обсуждение членов партии. Таким способом были подготовлены как берлинская предвыборная, так и программа партии, принятая на втором партийном съезде в Оффенбахе 3 декабря 2011 г. $^{58}$

Её основными положениями стали:

- заключение «безусловного базового соглашения», которое будет гарантировать государственную финансовую поддержку гражданам независимо от их имущественного положения и без принуждения к работе;

- гарантия безусловных сочииальных выплат и отмена сокращения денежных пособий, даже если получатели «Харц-IV» откажутся от предлагаемой им работы или будут уклоняться от других предписаний. По мнению «Пиратов», такие санкции, как ослабление социальной поддержки, а также другие взыскания, предусмотренные законодательством для безработных, наруша-

\footnotetext{
${ }^{57}$ В переводе с английского - «прозрачные отзывы».

58 Первая программа партии «Пираты» была принята в 2010 г. в г. Хемниц.
} 
ют их основные права по уважению человеческого достоинства (ст. 1) и противоречат запрету на принудительный труд (ст. 12 Основного Закона). Партия выступает за улучшение ситуации с безработными и отмену санкций «Xарц-IV» (или введение моратория на них);

- отделение изеркви от государства путём отмены церковного налога и других привилегий для социальных организаций церкви, а также отмена обязательного указания своей религиозной принадлежности для служащих государственных учреждений;

- легализация наркотиков и тем самым декриминализация их продажи, что подразумевает создание «структур, контролирующих продажу наркотиков»;

- введение бесплатного проезда в общественном трансnopme;

- создание свободной Интернет-сети, базирующейся на W-LAN-технологиях, независимой от государственного контроля и цензуры, которой можно будет пользоваться в любом месте бесплатно. Это должно облегчить доступ к Интернету дискриминированным слоям общества ${ }^{59}$.

В документах нет конкретных указаний на то, из каких источников должны финансироваться предложения партии, за исключением фразы о «повышении коммунальных взносов». Слово «налоги» «Пираты», видимо, сознательно не использовали.

Интересна концепция «Liquid Democracy» ${ }^{60}$. Сами «Пираты» дали следующее определение данному понятию: «Liquid Demoсracy» - это смешанная форма представительной и прямой демократии. Если в первом варианте интересы избирателей представляют делегаты, а во втором - сами граждане, то «прозрачная демократия» подразумевает текучий переход между двумя формами. Каждый участник процесса может сам решать, в какой степени он готов представлять свои интересы лично, а в какой быть представленным другими. В частности, каждый делегат должен быть готов к тому, что в любое время его право пред-

\footnotetext{
${ }^{59}$ Wiki der Piratenpartei Deutschland. URL: http://wiki.piratenpartei.de/ (дата обращения: 21.01.2012).

${ }^{60} \mathrm{~B}$ переводе с английского означает «прозрачная» или «текучая» демократия.
} 
ставлять интересы других граждан может быть отозвано ими до окончания избирательного срока. Это должно способствовать появлению постоянно находящейся в движении сети делегатов ${ }^{61}$. Другими словами, такая форма демократии может непрерывно превращаться из прямой в представительную и наоборот.

Некоторые немецкие исследователи посчитали, что вопросы Интернета и транспарентности не могут стать серьёзной мобилизующей темой для новой партии. А. Меркель в успехе «Пиратов» увидела «классический протест», сформированный восприятием, на которое Интернет оказал очень сильное влияние.

«Пираты» практически сразу столкнулись с серьёзной структурно-кадровой проблемой. Молодые люди пришли в политику, не имея опыта управления и чётких представлений о том, как следует относиться к своим новым обязанностям. Они не только недооценили объём предстоявшей им работы, но не успели осознать, какое значение имеют слова и какие последствия может повлечь неосторожность или излишняя откровенность с прессой. Примером такой непредусмотрительности может служить комментарий М. Делиуса, который в одном из интервью сравнил успех своей партии с успехом НСДАП в 1928-1933 гг. И, хотя он быстро извинился за своё высказывание, подобное сравнение вызвало резонанс в немецком обществе и стоило «Пиратам» многих голосов на следующих земельных выборах.

Провозгласив своей целью «прозрачность» демократии и открытое принятие решений внутри партии, «Пираты» принялись не только обсуждать волнующие их темы, но и публично выяснять отношения, доводя до прессы детали своих ссор и неурядиц, невольно подменив транспарентность политического процесса демонстрацией своей незрелости и некомпетентности. Особенно жёсткая конфронтация возникла между двумя ведущими лидерами - Й. Понадером и Б. Шлемером. Фактически их спор можно рассматривать как противостояние двух противоположных подходов к вопросу о будущем партии: должны ли «Пираты» следовать провозглашённым идеалам и стремиться все свои действия согласовывать с базисом партии или же скорректиро-

${ }^{61}$ Liquid Democracy. Wiki der Piratenpartei Deutschland. URL: http://wiki.piraten partei.de/Liquid_Democracy (дата обращения: 21.01.2012). 
вать свои принципы и взять курс на «профессионализацию». В любом случае, для того чтобы закрепиться в партийно-политической системе Германии, им следовало осознать ответственность, возложенную на партию её избирателями. Будущее «Пиратов» напрямую зависит от того, насколько хорошо они сумеют интегрироваться в повседневную политическую реальность и приспособиться к её институтам, а также от уровня доверия, которым будут пользоваться у избирателей традиционные партии. Чем меньше это доверие и выше недовольство партийнополитической системой у населения, тем больше шансов у «протестных партий».

\section{5. ВЛИЯНИЕ ПОЛИТИЧЕСКИХ СКАНДАЛОВ НА ПАРТИЙНУЮ СИСТЕМУ ГЕРМАНИИ}

Значительную роль в недовольстве немецких граждан развитием современной политической системы страны играют, на наш взгляд, довольно частые для Германии скандалы, связанные с политической элитой и первыми лицами государства. Так, в 2010 г. впервые в истории ФРГ Президент республики Х. Келлер (ХДС) досрочно отказался от исполнения своих обязанностей и добровольно ушёл в отставку. В 2011 г. с поста вице-канцлера и председателя партии свободных демократов был вынужден уйти министр иностранных дел Г. Вестервелле; покинул свой кабинет из-за обвинений в плагиате и бывший министр обороны К. Т. цу Гуттенберг (ХСС). 17 февраля 2012 г. настала очередь президента Германии Кристиана Вульфа, скандал вокруг которого разгорелся в конце 2011 г. из-за его тесных контактов с крупным бизнесом.

Вторая за полтора года отставка президента обострила и без того активную дискуссию в обществе о соответствии политиков и чиновников высокого ранга моральным принципам и в значительной степени подорвала доверие немецких избирателей к институтам власти. Согласно оценкам телевизионного канала ARD,

\footnotetext{
Материал данной главы первоначально был опубликован в: Тимошенкова Е.П. «Особенности партийно-политического развития ФРГ», Германия. 2011. Под ред. Белова В.Б. М., 2012. С. 53-77.
} 
53\% граждан были убеждены, что «большинство политиков используют своё служебное положение для получения экономических преимуществ», и только $3 \%$ верили, что «случай с К. Вульфом - скорее исключение» ${ }^{62}$. В немецком экспертном сообществе вновь заговорили о необходимости ввести прямые выборы президента и даже о целесообразности отменить этот институт ${ }^{63}$.

Тот факт, что второй президент подряд, избранный Федеральным собранием и, соответственно, представляющий собой выбор партий, вместо того, чтобы примирять и направлять немецкое общество своим примером, оказался в центре скандала, свидетельствует о значительном дефиците авторитета этих партий и их персонала. Однако недостаток доверия к народным партиям не означает эрозию Основного закона ФРГ и её государственного устройства, которые успешно функционируют уже более 50 лет.

Уход К. Вульфа поставил правящую коалицию и лично А. Меркель в довольно сложную ситуацию. В 2010 г. ей потребовалось приложить немало усилий, чтобы убедить своих коллег поддержать его кандидатуру. Кандидат от оппозиционных партий, правозащитник из бывшей ГДР Й. Гаук изначально был более популярен среди населения, пользовался большим авторитетом у политиков и потому был сильным конкурентом молодого и не столь известного премьер-министра из Нижней Саксонии. Однако А. Меркель предпочла видеть на этом посту более предсказуемого, обязанного ей своим взлётом коллегу по партии, нежели независимого, харизматичного, эмоционального и, соответственно, трудно контролируемого политика. Именно поэтому общественность восприняла отставку К. Вульфа как личную ошибку канцлера, которая не смогла сделать правильный выбор двумя годами ранее.

${ }^{62}$ ARD-Deutschland Trend: Erstmals klare Mehrheit für Wulfs-Rücktritt. URL: http://www.tagesschau.de/inland/deutschlandtrend1448-magnifier pos-6.html (дата обращения: 12.04.2012).

${ }^{63}$ Von den Präsidenten zur Parteiendämmerung, von Albrecht von Lucke. «Blätter» 2/2012. URL: http://www.blaetter.de/archiv/jahrgaenge/2012/februar/von-derpraesi denten-zur-parteiendaemmerung; Gauk ist Volkes Liebling, am 20.02.2012. URL: http://www.tagesspiegel.de/politik/nach-dem-wullf-ruecktritt-gauck-ist-vol kes-liebling/6229268.html (дата обращения: 12.04.2012). 
Таким образом, ситуация с выборами нового президента обострилась с самого начала. ХДС во главе с А. Меркель, предстояло найти такого кандидата, который привёл бы к консенсусу не только парламентариев, но и всё общество. Однако подобрать подходящую кандидатуру в партии не успели. Совершенно неожиданно положение осложнили свободные демократы: они публично заявили о своей поддержке кандидата от оппозиционных партий Й. Гаука, связав тем самым вопрос о его избрании с будущим правительственной коалиции.

Вице-канцлер Ф. Рёслер решился обострить отношения с ХДС вполне осознанно. После его назначения СвДП не только не вышла из кризиса, но более высокими темпами продолжила терять популярность у населения. Будучи в коалиции с ХДС, она не смогла претворить в жизнь ни одно положение своей предвыборной программы, тем более что её успех на федеральных выборах 2009 г. был обусловлен, прежде всего, обещанием снизить налоги. Размолвки со старшим партнёром по коалиции привели к тяжёлым внутренним разногласиям в партии, существенной потере голосов на земельных выборах и снижению рейтинга СвДП и Ф. Рёслера.

Особенного драматизма внутрипартийные противоречия достигли в вопросе помощи странам еврозоны, оказавшимся в затруднительном положении. Камнем преткновения стала позиция СвДП по голосованию в бундестаге о создании постоянного механизма Европейской стабильности, который должен был заменить Европейский фонд финансовой стабильности. Часть либералов была против введения этой меры и выступила в ноябре 2011 г. с инициативой внутрипартийного голосования по проблеме, итоги которого стали бы обязательными для всех членов партии и определили бы её официальную позицию. Если бы подобное решение состоялось, оно не только пошло бы вразрез с позицией Ф. Рёслера, поддержавшего федеральное правительство, но и поставило бы под вопрос дальнейшую работу либералов в коалиции с ХДС. Однако в начале декабря 2012 г. незадолго до окончания голосования руководство партии объявило о провале принятия решения из-за отсутствия необходимого кворума ${ }^{64}$.

${ }^{64}$ Вместо необходимого минимума в 21,5 тыс. было собрано 16 тыс. голосов. 
Это вызвало крайне негативную реакцию со стороны инициаторов голосования, которые обвинили Ф. Рёслера в неуважении к мнению большинства членов партии и заговорили о его отставке ${ }^{65}$.

В итоге в отставку ушёл генеральный секретарь СвДП Кристиан Линднер, который был назначен на эту должность ещё в 2009 г. при Г. Вестервелле и пользовался доверием не только своих коллег, но и политиков других партий. Именно он должен был разработать новую программу СвДП, на которую либералы возлагали большие надежды. Для многих либералов его уход стал большой неожиданностью и был воспринят как попытка продлить политические дни Ф. Рёслера, ответственного, с их точки зрения, за провал голосования о будущем еврозоны.

В начале декабря 2011 г. из-за «отсутствия доверия и лояльности» между членами отделения СвДП в Саaре с поста председателя фракции и затем из партии ушёл К. Шмидт. Бывшие коллеги не смогли договориться о его преемнике. Такая разрозненность либералов привела к досрочному окончанию правительственной коалиции с ХДС и поставила партию перед необходимостью готовиться к новым выборам, а сам факт досрочного прекращения коалиции в этой земле многие эксперты и политики стали рассматриваться как сигнал и для других земельных правительств ${ }^{66}$.

На фоне обострившихся отношений с ХДС и неустойчивости своего положения в качестве руководителя партии Ф. Рёслеру требовалась личная победа, которая продемонстрировала бы его решительность и помогла вернуть доверие к себе и СвДП. Выборы нового кандидата в президенты ФРГ предоставили подобную возможность. Переход свободных демократов на сторону оппозиции в данном вопросе буквально вынудил А. Меркель ценой сохранения коалиции и падения своего авторитета согласиться с кандидатурой Й. Гаука. Не случайно немецкие СМИ сравнили этот поступок Ф. Рёслера с «восстанием уни-

${ }^{65}$ Schäffler wirft Rösler Missachtung der Basis vor, am 11.12.2011. URL: http:// www.spiegel.de/politik/deutschland/0,1518,803019,00.html (дата обращения: 12.04.2012).

${ }^{66}$ Такое мнение, например, высказал председатель фракции «Зелёных» в бундестаге Джем Оздемир. 
женного». Для многих членов ХДС подобное проявление самостоятельности СвДП стало «огромным нарушением доверия», которое они не заслужили ${ }^{67}$.

Однако А. Меркель сумела достойно выйти из создавшегося положения, объявив о необходимости консенсуса всех партий и общества в деле выдвижения нового кандидата в президенты страны, и пригласив для консультаций оппозицию (за исключением партии «Левая») ${ }^{68}$.

\section{6. КОНЕЦ ПОЛИТИЧЕСКОГО КАТОЛИЦИЗМА В ФРГ?}

18 марта 2012 г. Й. Гаук, 72-летний пастор из Ростока, был избран представителями большинства немецких партий 11-м федеральным президентом ФРГ. С избранием Й. Гаука на эту должность два высших государственных поста в республике заняли протестанты, граждане бывшей ГДР. Это послужило определённым поводом для разговоров о том, что «никогда в политике Германии протестантизм не был выражен так сильно как сегодня» ${ }^{69}$. А. Меркель - дочь протестантского пастора - и раньше нередко упрекали в недостаточном внимании к христианским ценностям и, как следствие, в утрате партией ХДС её консервативного уклона.

Особенно сильной критике со стороны католиков канцлер подверглась в 2009 г., когда она позволила себе сделать публич-

${ }^{67}$ Gauck-Macher Rösler. Aufstand des Erniedrigten, von Severin Weiland, am 20. 02.2012. URL: http://www.spiegel.de/politik/deutschland/0,1518,816363,00.html (дата обращения: 12.04.2012).

68 Данное обстоятельство, на наш взгляд, является некорректным шагом по отношению к «левым», поскольку эта партия наряду с другими была избрана в бундестаг и наделена таким же правом представлять интересы той части немецких граждан, которые за неё проголосовали.

" Материал данной главы первоначально был опубликован в: Тимошенкова Е.П. «Особенности партийно-политического развития ФРГ», Германия. 2011. Под ред. Белова В.Б. М., 2012. С. 53-77.

${ }^{69}$ Die Protestanten übernehmen die Republik, von Robin Alexander, am 17.03. 2012. URL: http://www.welt.de/politik/deutschland/article13927747/Die-Protestan ten-uebernehmen-die-Republik.html; Protestanten Merkel und Gauck. Ende des politischen Katholizismus?, am 21.02.2012. URL: http://www.cicero.de//berliner-re publik/gauck-merkel-ostdeutschland-protestanten-ende-des-politischen-katholizis mus/48385 (дата обращения: 12.04.2012). 
ное замечание главе католической церкви - Папе Римскому за его недостаточно жёсткую позицию в отношении священника Ричарда Вильямсона, известного своими спорными высказываниями о Холокосте. Это произошло во время пресс-конференции А. Меркель с президентом Казахстана Нурсултаном Назарбаевым - лидером мусульманской страны, что ещё больше оскорбило чувства католиков. Извиняться тогда, как ей посоветовал кельнский кардинал Майсснер, канцлерин не стала ${ }^{70}$. Определённым образом инцидент отразился на визите Папы в Германию в конце сентября 2011 г. В своей насыщенной программе он выделил время для встреч с католиками из оппозиционных партий СДПГ и «зелёных», что вызвало обеспокоенность у консервативного крыла ХДС. По словам одного из ведущих немецких католиков, церковь не видит проблемы в том, что хорошие католики есть во всех партиях, но если раньше представители немецкой церкви чувствовали себя в ХДС как дома, то теперь, «их в ведомстве канцлера понимают, но домашней атмосферы они там не ощущают» ${ }^{71}$.

Став канцлером ФРГ, А. Меркель нарушила одно из негласных правил партии: большинство министерских позиций в правительстве должны занимать католики. С уходом в отставку цу Гуттенберга таких в её кабинете осталось лишь пятеро из 15 министров, тогда как при предыдущем канцлере ХДС Г. Коле подобное было немыслимо: при нём 11 из 19 министров были католиками. И даже в правительстве социал-демократа Г. Шрёдера соотношение в пользу последних было больше ${ }^{72}$. Сама канцлер не раз говорила, что при выборе кандидатов ориентируется прежде всего на их талант и способность справиться с поставленными задачами.

Такая тенденция привела к тому, что наиболее консервативно настроенные католики почувствовали, что их голос в совре-

${ }^{70}$ См. подробнее: С. Погорельская. Компас для нового курса. Эксперт, 2011, №46. C. 78 .

${ }^{71}$ Die alte Liebe der CDU zur Kirche ist erloschen, am 20.09.2011. URL: http:// www.welt.de/politik/specials/papst/article13616623/Die-alte-Liebe-der-CDU-zurKirche-ist-erloschen.html (дата обращения: 12.04.2012).

${ }^{72}$ Merkels neue K-Frage. Christ und Welt, Ausgabe 11/2011. URL: http://www. christundwelt.de/detail/artikel/merkels-neue-k-frage (дата обращения: 12.04.2012). 
менном ХДС звучит недостаточно чётко, и организовали в 2009 г. «кружок ангажированных католиков» (АЕК). Их целью стало возвращение в партию христианских ориентиров и веры, которых в последнее время ХДС явно не хватает ${ }^{73}$. Шестьюдесятью годами ранее при канцлере К. Аденауэре подобный кружок создали протестанты (ЕАК), уступавшие по численности католикам. Тогда их объединение сразу же получило статус партийной структуры, что означало, помимо финансирования из средств ХДС издания ежемесячного журнала и деятельности бюро, участие председателя объединения в качестве «обладающего правом совета» во всех заседаниях президиума партии и его право вносить от имени организации свои предложения на съездах. Однако «кружок ангажированных католиков», в отличие от протестантов, не получил официального статуса от А. Меркель и действует по собственной инициативе ${ }^{74}$.

Накануне партийного съезда ХДС в Лейпциге 14-15 ноября 2011 г. «ангажированные католики» выпустили манифест. В документе они выразили большую озабоченность положением партии, которая «теряет свою достоверность и, кажется, уже лишилась своего чёткого неизменного стиля». Многие постоянные избиратели, по мнению организации, отворачиваются от ХДС, потому что больше не находят в ней христианского ядра. Кроме того, за последние годы им пришлось стать очевидцами того, как быстро были отброшены ранее само собой разумеющиеся позиции и убеждения. «Кружок ангажированных католиков» призвал христианских демократов использовать съезд для «нещадного и бесстрашного анализа партии и её содержания» ${ }^{75}$. Однако съезд не оправдал возлагаемых на него ожиданий. Широкой дискуссии о консервативной составляющей ХДС, к которой призывали представители кружка, не получилось. Не удалось развернуть её внутри партии и в последующие годы.

\footnotetext{
${ }^{73}$ Landesverband des AEK gründet sich am Samstag. URL: http://www.sachsen-c du-politik.de/2011-11/kretschmer-katholiken-in-sachsen-werden-fuer-merkel-bete n-2530 (дата обращения: 12.04.2012).

${ }^{74}$ Bischöfe beklagen Merkels Distanz zur katholischen Kirche. URL: http://www. freiewelt.net/nachricht-8161/bisch\%F6fe-beklagen-merkels-distanz-zur-katholisch en-kirche.html (дата обращения: 12.04.2012).

AEK-Manifest zum CDU-Parteitag. URL: http://www.freiewelt.net/nachricht-

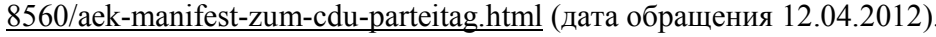


Если проследить политику Христианско-демократического союза и развитие его программных установок с прихода к власти А. Меркель, то можно констатировать кардинальные изменения во многих традиционных для партии положениях. Во-первых, это отказ от атомной энергетики, который провозгласил ХДС после катастрофы на «Фукусиме». Во-вторых, правительство, возглавляемое христианскими демократами, разработало и начало проводить военную реформу, предусматривающую отмену всеобеей воинской повинности и перевод армии на контрактную основу, что противоречит политическим традициям партии К. Аденауэра. Введение минимальной оплаты труда также не является характерной для консерваторов мерой и относится к требованиям социал-демократов. И, наконец, правительство отошло от принципа евроатлантической солидарности во внешней политике, когда воздержалось при голосовании по резолюции Совета Безопасности ООН, разрешающей применение военной силы против войск Муаммара Каддафи, и вывело части бундесвера из всех операций НАТО в Средиземном море по обеспечению военного эмбарго в отношении Ливии. К данному списку следует добавить внутрипартийные дискуссии 2013-2014 гг. о регистрации однополых браков и легализации эвтаназии тяжелобольным, принявшим решение о добровольном уходе из жизни.

Таким образом, идеология партии за последние годы существенно изменилась. Неудивительно, что некоторые члены ХДС стали говорить о том, что не узнают свою партию, и требовать возврата к её консервативной составляющей, среди прочего апеллируя к тому факту, что традиционные избиратели отворачиваются от неё. Например, только за 2011 г. христианские демократы потеряли около 10 тыс. своих сторонников ${ }^{76}$. Однако все ли они были приверженцами католицизма? Точный ответ на вопрос отсутствует. Известно, что из всех католиков, живущих в Германии, 75\% предпочитают голосовать за ХДС/ХСС, но эта часть составляет лишь $9 \%$ от всех избирателей ${ }^{77}$. К тому же в крупных городах, таких как Гамбург, Берлин или Бремен, кон-

\footnotetext{
${ }^{76}$ Ibid.

77 Доклад профессора Х. Оберройтера в Институте Европы РАН на тему: «Партийно-политическая система Германии сегодня» (13.03.2012).
} 
фессиональная принадлежность вообще не играет заметной роли при выборе. Снижение численности членов партии - общая тенденция, характерная для обеих народных партий. На сегодняшний день количество членов ХДС, так же как и СДПГ, не превышает 500 тыс. человек, что практически в 1,5 раза меньше, чем в начале 1980 -х гг. ${ }^{78}$

В сложившейся ситуации А. Меркель пытается расширить социальную базу Христианско-демократического союза и отвоевать избирателей у своих конкурентов, часто следуя за их переменчивыми настроениями в ущерб традиционным ценностям партии. В результате многие эксперты и критики упрекают её в отсутствии чётких политических ориентиров и целей. Ведо́мая страхом поражения на выборах, А. Меркель очень быстро меняет свои убеждения и принимает судьбоносные решения без серьёзных консультаций с членами партии, направляя тем самым ХДС «в никуда». С другой стороны, есть предположение, что она старается создать новый, более современный Христианскодемократический союз, который станет своего рода «партией граждан». Именно поэтому А. Меркель проводит политику не «христианского» патриотизма, характерного для ХДС со времён его основания, а «государственного» или «реального», пытаясь привлечь на свою сторону избирателей из новых федеральных земель, которые в большинстве своём не очень религиозны.

ХДС под руководством А. Меркель, несомненно, стал менее консервативным и многопрофильным - партии удалось перехватить темы, традиционно относящиеся к сфере СДПГ и «зелёных». С одной стороны, такая политика расширяет возможности партии создавать новые коалиции. С другой - дезориентирует избирателей, которые не знают, какое направление ХДС выберет завтра, и будет ли он придерживаться своих взглядов в дальнейшем. В любом случае такая сильная зависимость Христианскодемократического союза от политических взглядов одного человека неизбежно ведёт к отождествлению партии, её успеха или поражения с личностью канцлерин и ставит вопрос о будущем ХДС без А. Меркель и наличии в партии достойных преемников.

\footnotetext{
${ }^{78}$ Mitgliederentwicklung der Parteien. URL: http://www.bpb.de/themen/1YML48, 0,Mit gliederentwicklung.html (дата обращения 12.04.2012).
} 


\section{7. СОЗДАНИЕ НОВОЙ ПАРТИИ «АЛЬТЕРНАТИВА ДЛЯ ГЕРМАНИИ»}

Как уже отмечалось выше, отход ХДС, возглавляемого А. Меркель, от традиционных консервативных ценностей, а также экономическая политика партии по спасению еврозоны привели к усилению в ней недовольных голосов. Ощущение бессилия повлиять на дальнейшее развитие ХДС и безальтернативности проводимого канцлерин политического курса подтолкнуло некоторых представителей христианских демократов к решению выйти из союза и создать другую партию, выражающую их взгляды и представления о дальнейшем развитии Германии. Доверие к канцлерин оказалось подорванным после того, как А. Меркель 25 марта 2010 г. дала бундестагу обещание не оказывать прямую финансовую поддержку Греции, которое она нарушила спустя пару часов, придя к соглашению с главами государств и правительств ЕС о первом пакете помощи для оказавшейся на грани банкротства Греции.

Разочарованный в европейской политике правящей коалиции сопредседатель Совета малых и средних предпринимателей из правого консервативного крыла ХДС - Г. Робануссо, совместно с бывшим издателем и руководителем немецкой газеты «Markische Allgemeine Zeitung» А. Гауландом, журналистом К. Адамом и экономистом Б. Луке создали в 2012 г. «Избирательную альтернативу 2013» для участия в выборах в бундестаг. Она должна была стать предложением для всех, кто был недоволен политикой правительства по спасению еврозоны. Основатели движения были убеждены, что представления немецких граждан по данному вопросу кардинально отличаются от избранного коалицией курса, и ни одной из партий не удалось уловить эти настроения. Более того, страх партий быть обвинёнными в «антиевропейской» и «прогерманской» политике мешает им сформулировать и отстаивать перед другими европейскими государствами свои национальные интересы ${ }^{79} .13$ апреля 2013 г. основатели «Избирательной альтернативы 2013» объявили о создании собственной партии «Альтернатива для Германии».

${ }^{79}$ Enttäuschte CDU-Politiker gründen Wahlalternative. Die Welt, am 04.10.2012. 
Упрёки других политиков в том, что новая партия может стать заложницей одной темы, они отвергли. По их мнению, речь идёт не только о европейской политике, но и о верности договору и Конституции. Основатели «АдГ» отмечают общую инертность современной демократии, однако проблема евро для них выражена острее.

Призывы отстаивать национальные интересы в европейской политике, исходящие от этой партии, привлекательны не только для разочарованных сторонников ХДС/ХСС и СвДП, но и для избирателей других партий, поскольку им не удаётся представить убедительную альтернативную правительственному курсу программу не только в вопросе евроинтеграции, но и в целом. По оценкам некоторых исследователей, около трети немецких граждан испытывают скрытое недовольство политикой правительства в отношении еврозоны, тогда как открыто выразить свой протест и проголосовать за новую партию в 2013 г. были готовы лишь $3 \%{ }^{80}$. В результате на выборах в бундестаг в 2013 г. «Альтернативе для Германии» удалось набрать 4,7\%, что стало серьёзной заявкой на будущие успехи «АдГ». Партия может составить конкуренцию этаблированным партиям, если учтёт отрицательный опыт «Пиратов» и сумеет избежать неприятных сравнений с НСДАП и «коричневой» окраски программных положений. Подобные обвинения и призывы игнорировать новую партию, не сотрудничать с ней, видимо, станут главным оружием традиционных партий.

\section{8. ПОДГОТОВКА К ВЫБОРАМ В БУНДЕСТАГ 2013 г.}

Одним из самых заметных и важных событий в политической жизни Германии 2012 г. стало выдвижение кандидатом на пост канцлера от Социал-демократической партии П. Штайнб-

\footnotetext{
${ }^{80}$ Umfrage: Anti-Euro-Partei bei FDP- und Linke-Wählern beliebt. URL: http://ww w.wz-newsline.de/home/politik/inland/umfrage-anti-euro-partei-bei-fdp-und-linkewaehlern-beliebt-1.1294699; Experten sehen gute Chancen für neue eurokritische Partei. URL: http://www.wZ-newsline.de/home/politik/inland/experten-sehen-gutechancen-fuer-neue-eurokritische-partei-1.1293569 (дата обращения: 17.12. 2012).

Материал данной главы первоначально был опубликован в: Тимошенкова Е.П. Германия 2012 - предвыборное настроение (за год до федеральных выборов). Германия 2012. Под ред. Белова В.Б. М., 2013. С. 47-84.
} 
pюка $^{81}$. В СДПГ обсуждали и другие кандидатуры, например, бывшего министра иностранных дел Ф.-В. Штайнмайера и председателя партии Зигмара Габриэля. После убедительной победы Хенелоры Крафт на земельных выборах в Северном РейнВестфалии, которая выиграла у федерального министра экологии Н. Рёттгена, представлявшего правящую партию ХДС (СДПГ набрала $39,1 \%$ голосов, ХДС - 26,3\%), многим казалось, что именно она должна повести за собой социал-демократов на федеральных выборах 2013 г. и противостоять А. Меркель. Однако Х. Крафт исключила для себя подобную возможность и осталась министром-президентом Северного Рейн-Вестфалии. Ведь именно нежелание Н. Рёттгена в случае поражения на выборах покинуть Берлин и возглавить оппозицию во многом предопределило его проигрыш и уход из Кабинета министров.

Ф.-В. Штайнмайер, который уже участвовал в выборах 2009 г. в качестве кандидата на пост канцлера от СДПГ и сокрушительно проиграл А. Меркель, не захотел повторять свой опыт. К тому же его интеллигентная и спокойная манера вести дебаты не очень подходила для мобилизации избирателей и агрессивной предвыборной кампании против действующего канцлера.

Для председателя СДПГ 3. Габриэля выбор кандидатуры П. Штайнбрюка оказался вполне логичным и приемлемым. В ситуации необычайно высокой популярности у населения действующего канцлера А. Меркель, когда шансы СДПГ на победу были невысоки, любой кандидат от партии сильно рисковал. К тому же 3. Габриэль - самый молодой из тройки лидеров и у него было достаточно времени для того, чтобы правильно спланировать свою карьеру.

То, что федеральную избирательную кампанию социал-демократов, скорее всего, возглавит П. Штайнбрюк, стало ясно уже в начале осени 2012 г. В сентябре, выступая перед фракцией СДПГ на «конгрессе будущего», он резко раскритиковал Христианско-демократический союз за его «обывательский буржуазный характер» и выступил за введение налоговых послабле-

${ }^{81}$ Пеер Штайнбрюк - социал-демократ, родился 10 января 1947 г. в г. Гамбург, в 2002-2005 гг. - министр-президент федеральной земли Северный Рейн-Вестфалия, в 2005-2009 гг. - федеральный министр финансов и заместитель председателя партии СДПГ, с 2009 г. - член бундестага. 
ний для одиноких матерей и гражданских союзов, заключённых между лицами нетрадиционной ориентации. 1 октября 2012 г. правление СДПГ единогласно выдвинуло П. Штайнбрюка в качестве кандидата в канцлеры в избирательной кампании 2013 г. В декабре 2012 г. на специальном съезде социал-демократов за его кандидатуру проголосовало 93,45\% участников, что стало далеко не лучшим результатом в истории партии. Меньшее количество голосов получил в 1998 г. лишь Г. Шрёдер, что не помешало ему в своё время привести СДПГ к победе. Как и его предшественник, П. Штайнбрюк, придерживаясь либеральных взглядов, не был идеальным кандидатом для всех социал-демократов.

Изначально в СДПГ не планировали называть кандидата так рано, поскольку противостоять популярной А. Меркель и держать в напряжении избирателей практически в течение года, не допустив ошибок, - очень непростая задача. Однако в прессу просочилась информация о результатах переговоров между лидерами партии. Было необходимо придать «импульс» СДПГ перед выборами в Нижней Саксонии и помочь таким образом победить популярного у избирателей этой земли министра-президента Д. МакАлистра. Лидеры партии приняли решение объявить о выдвижении кандидата заранее. К тому же назначение П. Штайнбрюка в начале декабря 2012 г. стало ответом социалдемократов на съезд ХДС, на котором А. Меркель номинировали в качестве кандидата на пост канцлера в 2013 г. За неё проголосовало $98 \%$ делегатов.

Выдвижение П. Штайнбрюка в кандидаты на пост канцлера от СДПГ могло стать неплохим шансом для свободных демократов остаться у власти и помочь им достойно выйти из союза с ХДС/ХСС, участие в котором привело к глубокому кризису партии и поставило под вопрос её способность войти в новый состав бундестага в сентябре 2013 г. Политический дилетантизм вице-канцлера Ф. Рёслера и борьба за лидерство в руководстве СвДП позволили А. Меркель, и без того склонной перекладывать непопулярные решения и ошибки на своих младших партнёров по коалиции, успешно продолжать играть роль надпартийного модератора. Более того, она смогла укрепить позиции собственной партии, приведя отношения в коалиции фактически 
к состоянию оппозиционной войны между сильным ХДС и слабой СвДП. Лавирование христианских демократов влево под руководством А. Меркель, чтобы привлечь традиционных избирателей СДПГ, натолкнулось на жёсткое неприятие со стороны их младшего партнёра - свободных демократов. Они вошли в правительство благодаря либеральным лозунгам и стремились любой ценой реализовать хотя бы часть своих предвыборных обещаний. Это могло позволить им в условиях резкого падения доверия к партии и оттока избирателей оправдать своё пребывание в правительственной коалиции и мобилизовать оставшихся сторонников.

Фактически в 2012 г., за год до новых федеральных выборов, в правительственной коалиции сложилась ситуация, когда каждому из участников, включая ХСС, для привлечения избирателей потребовались собственные победы. Они были готовы их достигать, в том числе, за счёт ущемления интересов своих партнёров. Особенно наглядно противоречие интересов проявилось во время затянувшегося на месяцы спора вокруг важного для ХДС/ХСС проекта введения денежного пособия по уходу за маленькими детьми. Не менее жаркие дискуссии между СвДП и ХДС/ХСС велись и по другим вопросам. Спор вызвали намерения ХДС ввести минимальную оплату труда в областях, которые не регулируются тарифными соглашениями; повысить пенсионные пособия и консолидировать бюджет. Либералы требовали отменить взнос в фонд солидарности для восстановления восточных земель - идея, которую они включили в свою обновлённую предвыборную программу, и остро критиковали закон «о возобновляемых источниках энергии», который, по их мнению, представлял собой меру «чисто плановой экономики» ${ }^{82}$.

В целом довольно трудно найти вопрос, по которому партнёрам по правящей коалиции удалось бы быстро и без лишней эмоциональности прийти к компромиссу. Нежелание ХДС/ХСС и СвДП договариваться и уступать друг другу привели к тому, что у избирателей возникли объективные сомнения в жизнеспособности их союза, что отразилось, в первую очередь, на рейтингах СвДП и её председателя - вице-канцлера Ф. Рёслера.

${ }^{82}$ Rösler zerlegt die Pläne der Union. Süddeutsche Zeitung, am 21.10.12. 
В сложившейся ситуации выдвижение П. Штайнбрюка в качестве кандидата на пост канцлера от СДПГ некоторые либералы встретили с оптимизмом. Так, например, председатель фракции СвДП Шлезвиг-Гольштейна В. Кубики не раз подчёркивал, что решение социал-демократов «открывает для СвДП новые опции», и что с «прагматиком Штайнбрюком возможно решение проблем, о которых некоторые сегодня даже не думают» ${ }^{83}$. Однако его позиция не стала основной линией партии. В. Кубики всегда отличали особое мнение, часто не связанное с общей концепцией партии, и умение эпатировать публику, за что его прозвали «северным курфюрстом» и «этим ужасным инфантом». Избирательные кампании в Шлезвиг-Гольштейне давно воспринимали в партии и обществе как «шоу одного человека». Следует отметить, что они были успешными. В. Кубики не обманул ожиданий либералов и на этот раз, сумев принести своей партии 6 мая 2012 г. 8,2\% голосов. Если учесть, что ранее СвДП проиграла подряд несколько земельных выборов, и общий рейтинг партии колебался между 2 и 4\%, то этот показатель можно рассматривать как достижение. Такой высокий результат на фоне общего катастрофического снижения популярности свободных демократов укрепил положение В. Кубики в партии и в его собственных глазах, позволив ему развернуть массированное наступление против политики Ф. Рёслера «во имя спасения СвДП». По мнению В. Кубики, «представления половины избирателей о партии отличались от того, что думал и предлагал Ф. Рёслер», а «социальный либерализм означает, что СвДП всегда должна относиться к своим политическим партнёрам критично» ${ }^{84}$.

Этот тезис В. Кубики частично разделил и К. Линднер, которому через неделю после выборов в Шлезвиг-Гольштейне удалось повторить успех своего коллеги в Северном Рейн-Вестфалии и набрать $8,6 \%$ голосов, в том числе потому, что он не стал акцентировать избирательную кампанию либералов на сою-

${ }^{83}$ Und was sagen die anderen Parteien zu Steinbrück?, von Sabine Beikler, Robert Birnbaum; Cicero, am 29.09.2012/ URL: http://www.cicero.de/berliner-republik/ spd-kanzlerkandidat-und-was-sagen-die-anderen-parteien-zu-steinbrueck/52034 (дата обращения: 12.12.2012).

${ }^{84}$ Rösler-Interview für die «Hannoversche Allgemeine Zeitung», am 03.01.2013. URL: http://www.liberale.de (дата обращения: 14.01.2013). 
зе с ХДС. Под руководством бывшего секретаря СвДП К. Линднера либералам удалось не только попасть в парламент этой земли, преодолев 5\%-ный избирательный барьер, но и увеличить своё представительство в ландтаге до 22 человек (это на 9 мандатов больше, чем в 2010 г.). Хотя анализ выборов выявил, что личность К. Линднера едва ли оказала существенное влияние на исход голосования. По крайней мере, не в таком масштабе как В. Кубики: лишь 33\% избирателей в Северном Рейн-Вестфалии подтвердили, что они поддержали партию из-за кандидатуры К. Линднера, тогда как в Шлезвиг-Гольштейне личный фактор стал решающим для $66 \%$ избирателей ${ }^{85}$. Тем не менее, пресса окрестила К. Линднера «новой надеждой СвДП».

Успех В. Кубики и К. Лиднера стал, на наш взгляд, уникальным явлением: на фоне общего катастрофического оттока избирателей от СвДП два земельных лидера добились успеха на выборах благодаря отходу от официальной позиции партии, и это не стало достаточным побудительным стимулом для корректировки её программных положений. Как подчеркнул в одном из интервью Ф. Рёслер, снижение налогов - это та либеральная тема, которая отличает свободных демократов от других ${ }^{86}$. Соответственно, основным предвыборным предложением СвДП стало введение «правил экономии для государства», которые должны были не только способствовать консолидации бюджета, освобождению его от долгов, но и привести к отказу от ненужного повышения налогов ${ }^{87}$.

Перед выборами в бундестаг 2013 г. Ф. Рёслер испытывал на себе давление с трёх сторон - со стороны эгоцентричного и эпатажного В. Кубики, который представлял больше собственные интересы, нежели базисные позиции партии, и был мастером провокаций; молодого, но успевшего заслужить уважение коллег и политиков из других партий К. Линднера, которому симпатизировали молодые либералы; а также опытного, представ-

${ }^{85}$ Landtagswahl in Nordrhein-Westfalen, am 13.05.2012. Wahlanalyse. Konrad Adenauer Stiftung.

${ }^{86}$ Rösler-Interview für die «Hannoversche Allgemeine Zeitung», am 03.01.2013. URL: http://www.liberale.de (дата обращения: 14.01.2013).

87 Programm für die Bundestagswahl. Sparregel für den Staat. URL: http://www.liberale.de (дата обращения: 24.12.2012). 
ляющего интересы традиционной клиентуры СвДП - Р. Брюдерле, который в 2011 г. был вынужден уступить Ф. Рёслеру свой пост министра экономики и технологии и возглавить фракцию в бундестаге. Однако брожение вокруг лидера партии и вице-канцлера Ф. Рёслера оказалось не единственной проблемой СвДП перед выборами в бундестаг 2013 г. У партии не было интересных идей, которые могли бы объединить её сторонников и сделать её программу более убедительной для избирателей. Не решили эту задачу ни т.н. «Карлсрурские тезисы свободы», в которых Свободная демократическая партия была провозглашена «единственной партией свободы в Германии», ни съезд партии в мае 2013 г. ${ }^{88}$

Тем не менее, рассуждения о возможности коалиции из СДПГ, СвДП и «Союза 90/Зелёные» встретили серьёзное неприятие со стороны последнего. Партию «зелёных» сама кандидатура социал-демократов вполне устраивала. У них уже имелся опыт работы с П. Штайнбрюком во времена красно-зелёной коалиции в Северном Рейн-Вестфалии (2002-2005 гг.), когда он был министром-президентом этой земли.

Следует заметить, что сам П. Штайнбрюк при встрече с лидерами «зелёных» и их кандидатами на выборы 2013 г. - Юргеном Тритином и Катрин Геринг-Экардт - для обсуждения предвыборной стратегии отметил: «обе партии вместе стремятся выиграть, однако требование "зелёных" о равноправном союзе в случае победы он рассматривает критично... Конечно, обращение между партнёрами по коалиции должно быть корректным и честным, но речь будет идти и о политическом весе... Если одна партия наберёт в двое больше голосов или ещё больше, чем их младший партнёр, то чувство собственного достоинства никто терять не будет», - подчеркнул он ${ }^{89}$. Тем самым социал-демократы с самого начала чётко обозначили распределение ролей в этом союзе.

Анализ итогов земельных выборов 2012-2013 гг. выявил ин-

\footnotetext{
88 21-22 апреля 2012 г. в г. Карлсруэ состоялся 63-й партийный съезд СвДП, на котором была принята новая программа партии «Ответственность за свободу. Карлсрурские тезисы свободы за открытое гражданское общество».

89 Steinbrück will die Grünen auf Distanz halten, am 25.11.2012. URL: http:// www.tagesschau.de/inland/steinbrueck604.html (дата обращения: 24.12.2012).
} 
тересную тенденцию. Несмотря на неплохой результат, который продемонстрировали «зелёные» (в Сааре они набрали 5\%, в Шлезвиг-Гольштейне - 13,2\%, в Северном Рейн-Вестфалии $11,3 \%$, Нижней Саксонии - 13,7\%), состав их избирателей по сравнению с предыдущими годами начал заметно изменяться. Если пару десятилетий назад они переманивали избирателей у СДПГ, то теперь наметился обратный отток ${ }^{90}$. Более того, «Сою3 90/Зелёные» пополнил свои ряды за счёт сторонников ХДС и СвДП. Так, например, на выборах в Шлезвиг-Гольштейне к ним ушло 4 тыс. прежних избирателей ХДС и 6 тыс. от СвДП; в Северном Рейне-Вестфалии - 20 тыс. сторонников ХДС и 10 тыс. от СвДП; в Нижней Саксонии - 20 тыс. прежних избирателей $\mathrm{XД \textrm {C } ^ { 9 1 }}$.

В этой связи 3. Габриэль назвал «Союз 90/Зелёные» «новой СвДП», что, на наш взгляд, не совсем верно ${ }^{92}$. Эти партии занимают разные места в политической системе ФРГ и разительно отличаются по своим программным установкам: свободные демократы придерживаются либерально-экономических взглядов, «зелёные» выступают за введение налога на имущество и увеличение максимальной налоговой ставки; электорат, на который ориентируется СвДП, находиться справа от политического центра, «Союз 90/Зелёные» берёт левее и т.д. И всё же со временем «зелёным» удалось гораздо ближе сдвинуться к «середине», нежели свободным демократам, что отразилось и на численности партий. В 2012 г. они не только догнали по этому показателю либералов, но и сумели их опередить ${ }^{93}$. Следовательно, в будущем «зелёные» могли бы, на наш взгляд, взять на себя роль, с

${ }^{90}$ Так, например, в Северном Рейн-Вестфалии к социал-демократам от «Зелёных» ушло 70000, в Шлезвиг-Гольштейне - 14000, в Сааре - 6000 сторонников. ${ }^{91}$ Landtagswahl im Saarland, Landtagswahl im Schleswig-Holstein, Landtagswahl im Niedersachsen. Wahlanalyse. Konrad Adenauer Stiftung.

${ }^{92}$ Цит. по: Die Grünen blasen zum Angriff auf CDU. Cicero, am 30.11.2012. URL: http://www.cicero.de/berliner-republik/die-gruenen-blasen-zum-angriff-aufdie-cdu/52732 (дата обращения: 24.12.2012).

${ }^{93}$ Партия «Союз 90/Зелёные» насчитывала в 2012 г. 60003 человека, тогда как количество членов СвДП уменьшилось до 58 575. См.: Mitgliederzahl der SPD sinkt auf Rekordtief. Die Welt. URL: http://www.welt.de/politik/deutschland/arti cle113893266/Mitgliederzahl-der-SPD-sinkt-auf-Rekordtief.html (дата обращения: 24.12.2012). 
которой когда-то успешно справлялись свободные демократы, и стать тем самым «флюгером», от которого будет зависеть, какая партия - СДПГ или ХДС/ХСС - окажется у власти. Если раньше избиратели воспринимали СвДП как партию, традиционно отстаивающую права и свободы граждан, то со временем эта «монополия» стала рассеиваться. «Союз 90/Зелёные» со своего появления уделял большое внимание вопросам защиты гражданских прав. Сейчас в Германии нет ни одной партии, которая игнорировала бы эту тему. Даже председатель «Пиратов» Бернд Шлемер и тот объявил на партийном съезде: «Мы социальная и либеральная партия, защищающая права граждан» ${ }^{94}$. Таким образом, защита прав и свобод граждан стала неотьемлемой частью имиджа всех современных партий.

Несомненно, ещё 20-30 лет назад идеологическая поляризация партий была выражена гораздо острее. Сегодня практически все партии, за исключением «Левой», борются за голоса избирателей так называемой «середины». В вопросах экономики и финансов, социальной политики, роли государства в программах СДПГ, ХДС и «Союза 90/Зелёные» появилось достаточное количество пунктов для сближения. Тема охраны окружающей среды, которая была визитной карточкой «зелёных», теперь взяли на вооружение все партии. И даже такие вопросы, как права людей с нетрадиционной ориентацией, одинаковое налоговое обложение зарегистрированных союзов и гражданских партнёрств, не являются больше табу для консервативной ХДС и, следовательно, не могут стать непреодолимыми препятствиями для сотрудничества. Более того, «зелёные» давно позиционируют себя как партия, которая не только готова распределять средства налогоплательщиков для повышения благосостояния граждан, но и думает о том, как их заработать. Участие в правительственных коалициях с СДПГ дало им хороший опыт. Они выступают за устойчивую политику в области финансов и экономики, что доказали во время финансового кризиса, поддержав политику А. Меркель. И даже в сфере, традиционно одной из основ политики ХДС/ХСС - поддержания христианских ценностей «зелёные» способны составить конкуренцию и привлечь на свою

${ }^{94}$ Ibid. 
сторону избирателей. Так, например, К. Гёринг-Экардт занимает пост председателя синода евангелистской церкви Германии, министр-президент земли Баден-Вюртемберг В. Кретчман член центрального комитета немецких католиков.

Всё это повышает политический вес партии и делает её более привлекательным партнёром не только для СДПГ, но и для ХДС. И некоторые представители Христианско-демократического союза стали говорить об этом открыто. Так председатель фракции ХДС в Северном Рейне-Вестфалии Армин Лашет высказал мнение, что хотя дебаты о создании чёрно-зелёной коалиции носят чисто теоретический характер, исключать такую возможность не следует. «В вопросах внешней и европейской политики у нас много общего, также и в области энергетики мы стали гораздо ближе. Основное различие состоит в том, что “зелёные" переоценивают нравственный аспект экологии и недооценивают значение рабочих мест в индустрии. И, конечно, главное противоречие кроется в отношении к финансовым вопросам: они выступают за повышение налогов»,- считает политик ${ }^{95}$.

16 ноября 2012 г. в Ганновере состоялся съезд партии «Сою3 90/Зелёные», девизом которого можно считать слова К. Гёринг-Экардт: «Доро́гой ХДС, доро́гой ХСС, дело в том, что мы хотим завоевать ваших избирателей. Вас мы не хотим!» ${ }^{96}$ И как было показано выше, у христианских демократов были все основания отнестись к этому обещанию серьёзно. Помимо чётких заявлений о своём нежелании кооперироваться в будущем с ХДС/ХСС, «зелёные» приняли ряд программных положений, которые ещё больше сблизили их предвыборную кампанию с СДПГ. Они также выступили за повышение налогов и единое гражданское медицинское страхование ${ }^{97}$. Предложили ввести

95 Armin Laschet. Grün ist unser Hauptgegner im Kampf um die Mitte. Welt am Sonntag, am 18.11.12. URL: http://www.welt.de/politik/deutschland/article111244 839/Gruen-ist-unser-Hauptgegner-im-Kampf-um-die-Mitte.html (дата обращения: 24.12.2012).

${ }^{96}$ Grünen-Parteitag: CDU? Och, nö! Spiegel-Online. URL: http://www.spiegel.de/ politik/deutschland/gruene-feiern-zu-beginn-des-parteitags-ihre-spitzenkandidatena-867755.html (дата обращения: 24.12.2012).

97 Так, подоходный налог планировалось увеличить до $49 \%$ при доходе на одного человека от 80000 евро в год, доход на имущество стоимостью более 1 млн евро - на 1,5\%, предусматривалось увеличение налога на наследство. 
минимальную оплату труда, «гарантированную» пенсию, повысить пособия по «Харц-4», создать лучшие условия для интеграции безработных в общество, расширить права переселенцев и обеспечить к 2030 г. переход на возобновляемые источники энергии, что должно привести к отказу от использования угля и т.д. ${ }^{98}$

Таким образом, «зелёные» уже в 2012 г. сделали однозначную ставку на союз с социал-демократами на выборах в бундестаг 2013 г. Однако при объявлении П. Штайнбрюка кандидатом на пост канцлера от СДПГ совместный рейтинг партий составлял 40\%, тогда как за правительственную коалицию готово было проголосовать 42\% граждан. К началу 2013 г. этот показатель значительно снизился, во многом из-за падения популярности самого П. Штайнбрюка. Если в сентябре 2012 г. за него были готовы проголосовать 37\% немецких граждан, то в январе 2013 г. только 25\%. Рейтинг СДПГ упал до 28\%, против 42\% у ХДС, тогда как популярность «зелёных» осталась на прежнем уровне $13 \%{ }^{99}$.

Помочь СДПГ и «Союзу 90/Зелёные» в борьбе против чёрно-жёлтой коалиции могли бы, на наш взгляд, «левые». Они также выступали за повышение налогов и усиление контроля над деятельностью банков. И хотя выдвижение П. Штайнбрюка не стало для них радостной новостью, мнения в партии о возможности войти в будущую коалицию с СДПГ и «зелёными» разделились, что возродило спор о целесообразности их дальнейшего пребывания в оппозиции. Например, с точки зрения сопредседателя «Левой» Бернда Рихингера, решение СДПГ о кандидате на пост канцлера повысило шансы его партии, по-

${ }^{98}$ Grünen-Parteitag. Beschlüsse aus Hannover, am 18.11.2012. URL: http://www.s piegel.de/politik/deutschland/gruenen-parteitag-beschluesse-aus-hannover-a-86787 7.html (дата обращения: 24.12.2012).

99 Уменьшилась поддержка П. Штайнбрюка и среди сторонников социал-демократов: в декабре 2012 г. его хотели видеть на посту канцлера 79\%, в янваpe 2013 г. - 63\%. Среди сторонников партии «зелёных» этот показатель составлял 47\%. Избирателям «левых» больше нравилась канцлер А. Меркель. За неё в январе 2013 г. готовы были проголосовать 56\%, тогда как за П. Штайнбрюка - 25\%. Данные полит-барометра «ZDF» от 11.01.2013. Cм.: SPD stützt abgestürzten Steinbrück - Rekordhoch für Union. Der Tagesspiegel. URL: http:// www.tagesspiegel.de/politik/politbarometer-spd-stuetzt-abgestuerzten-steinbrueckrekordhoch-fuer-union/7615978.html (дата обращения: 21.03.2013). 
тому что для многих сторонников социал-демократов это могло бы стать «хорошей причиной проголосовать за “левых"» ${ }^{100}$.

Борьба за избирателей и привлечение новых сторонников оказалась особенно актуальной проблемой для партии, которой в 2012 г. удалось войти лишь в один парламент - земли Саара, где она традиционно пользуется сильной поддержкой у населения. Несмотря на хороший результат в $16,1 \%$, которого удалось добиться «левым», это на 5,1\% меньше, чем на предыдущих вы$\operatorname{бopax}^{101}$. В Шлезвиг-Гольштейне, Северном Рейн-Вестфалии и Нижней Саксонии они не сумели войти в ландтаги и потеряли избирателей практически по всем направлениям. Так, например, на выборах 20 января 2013 г. в Нижней Саксонии «левые» столкнулись с наибольшими потерями: 17 тыс. традиционных избирателей ушли к «зелёным», 15 тыс. - к СДПГ, 10 тыс. - к ХДС, а 40 тыс. и вовсе остались в этот день дома ${ }^{102}$. В такой ситуации голоса тех, кто хотели бы вывести партию из оппозиции и придать её развитию новый импульс, усилились. Сопредседатель партии Катя Киппинг выразила симпатии возможному союзу между СДПГ, «зелёными» и «левыми». «Для нас имеет значение не персона П. Штайнбрюка, а программа... К тому же решение о заключении союзов принимают не кандидаты, а партии. И если они умны, то после выборов», - подчеркнула она в интервью для «Hamburger Abendblatt» ${ }^{103}$. Как показали результаты опросов общественного мнения в Германии, избиратели партий левого спектра, голосуя за партию, больше ориентируются на её программу, нежели на кандидатов; последнее более характерно для сторонников консервативного лагеря.

В принципе, значительная часть представителей «Левой» накануне выборов в бундестаг исходила из того, что без них со-

\footnotetext{
${ }^{100}$ Steinbrück erteilt Linken und Piraten eine Abfuhr, am 30.09.2012. URL: http:// www.zeit.de/politik/deutschland/2012-09/spd-kanzlerkandidat-steinbrueck-umfrage (дата обращения: 21.03.2013).

${ }^{101}$ Wahlergebnisse. URL: http://www.wahlrecht.de/ergebnisse/ (дата обращения: 24.12.2012).

${ }^{102}$ Landtagswahl im Niedersachsen, am 20.01.2013. Wahlanalyse. Konrad Adenauer Stiftung.

103 «Steinbrück erteilt Linken und Piraten eine Abfuhr». ZEIT ONLINE, am 30.09.2012; URL: http://www.zeit.de/politik/deutschland/2012-09/spd-kanzlerkan didat-steinbrueck-umfrage (дата обращения: 24.10.2012).
} 
циал-демократам и «зелёным» не справиться с поставленной задачей, и для того, чтобы сместить А. Меркель, им всё же придётся задуматься о заключении красно-красно-зелёного союза. Лидер «левых» Грегор Гизи не раз подчёркивал, что заключение союза с его партией не может произойти автоматически, без выдвижения условий с её стороны.

Однако все эти рассуждения и споры «левых» о целесообразности присоединения к СДПГ и «зелёным» не нашли поддержки у социал-демократов. 3. Габриэль, комментируя перспективы подобной коалиции, отметил: «Невозможно управлять такой огромной экономикой Европы с партией, которая не будет знать утром, какая её часть вечером проголосует за коалицию». «Левая», по мнению 3. Габриэля - «расколотая партия, состоящая из двух частей: из очень прагматичных восточных немцев, и всех тех, кто выделился из Западной Германии, и чей сою3, так сказать, враждебен по отношению к СДПГ» ${ }^{104}$. Нежелание социал-демократов объединяться с «левыми» официально подтвердил и П. Штайнбрюк. Таким образом, СДПГ в очередной раз отказалась от возможности сотрудничества с партией «Левая» на федеральном уровне, тем самым исключив вариант образования красно-красно-зелёного правительства до выборов.

\section{9. ВЫБОРЫ В ГЕРМАНСКИЙ БУНДЕСТАГ 2013 Г.: ИТОГИ И ОСОБЕННОСТИ}

22 сентября 2013 г. в ФРГ состоялись выборы в нижнюю палату парламента. С одной стороны, они запомнились как бесспорная победа Христианско-демократического союза и личный триумф А. Меркель, в итоге ставшей федеральным канцлером в третий раз. С другой, - как беспрецедентное поражение либералов, старейшей немецкой партии и партнёров ХДС/ХСС по пра-

104 «Gabriel im "Bericht aus Berlin": SPD steht weiter zu Steinbrück», am 13.01.2012. URL: http://www.tagesschau.de/inland/spdgabriel102.html (дата обращения: 12.04.2012).

Материал данной главы первоначально был опубликован в: Тимошенкова Е.П. «Выборы в германский парламент: основные результаты и их влияние на партийно-политическую систему Германии», Германия.2013. Под ред. В.Б. Белова. М., 2014. С. 11-34. 
вительственной коалиции 2009-2013 гг., которые впервые за всю историю своего послевоенного развития не сумели преодолеть 5\%-ный избирательный барьер и не вошли в бундестаг. В 2013 г. федеральные выборы впервые проходили по новым правилам, которые существенно изменили привычный порядок формирования нижней палаты парламента и повлияли на конечные итоги голосования.

\section{1. Реформа метода распределения мест в бундестаге}

До 2013 г. распределение мест в бундестаге происходило по методу немецкого математика Нимайера: количество голосов, отданных за партию на федеральном уровне, умножали на количество мест в парламенте и делили на общее количество голосов, отданных за все партии, преодолевшие $5 \%$-ный барьер ${ }^{105}$. На втором этапе эти места распределяли для каждой партии по землям в соответствии с набранными там вторыми голосами. Сначала полученные места заполняли те депутаты, которые получили «прямой» мандат, т.е. победили в избирательном округе по первому голосу. Затем оставшиеся места занимали кандидаты по земельному списку в соответствии с установленной в нём очерёдностью. У партий могли возникнуть т.н. «лишние мандаты» (Überhangsmandaten), т.е. если одна из них в избирательных округа́х определённой земли посредством первых голосов получала больше мест, чем ей было положено в этой земле по количеству вторых голосов. Поскольку депутаты, избранные прямым образом, обязательно должны войти в бундестаг, количество мест, предусмотренных для партии в федеральном парламенте, автоматически увеличивалось на количество «лишних» мандатов. Такая ситуация приводила к нарушению принципа, закреплённого в Основном Законе о равенстве голосов, согласно которому партии должны быть представлены в парламенте пропорционально отданным за них голосам. Получалось, что партия с «лишними» мандатами, набрав меньшее количество вторых голосов, чем другие партии, несмотря на худший результат, могла увеличить своё представительство в бундестаге в процентном соотношении к другим, более успешным на выборах партиям.

105 Обычно при распределении мест в бундестаге исходили из численности депутатов в 598 человек. 
3 июля 2008 г. Конституционный суд ФРГ объявил этот метод распределения мест в нижней палате парламента «противоречащим Конституции» и обязал бундестаг внести изменения в Федеральный закон о выборах до 30 июня 2011 г. Однако проект, разработанный к этому времени правительственными фракциями ХДС/ХСС и СвДП, не устроил оппозиционные партии, которые потребовали проверить соответствие предлагаемых изменений конституционным нормам. В результате Конституционный суд раскритиковал основные положения новой системы распределения мест в парламенте и признал их недействительными. В 2012 г. большинству партий в бундестаге (исключение составила партия «Левая») удалось прийти к консенсусу и провести реформу избирательной системы, на основании которой и был сформирован бундестаг, избранный 22 сентября 2013 г. ${ }^{106}$

Согласно новому закону, распределение мест в бундестаге должно быть «гарантированно пропорциональным» отданным за партии голосам и предусматривает выравнивание «лишних мандатов» за счёт увеличения количества мест для других партий. Это должно происходить до тех пор, пока не будет восстановлена пропорция (по вторым голосам) согласно результатам голосования.

\section{2. Результаты выборов в нижнюю палату парламента}

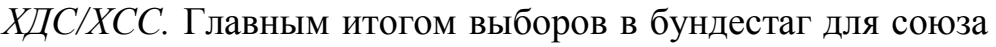
ХДС/ХСС стали рекордно высокие показатели на фоне результатов других партий. В общей сумме им удалось набрать 41,5\% вторых голосов. Из них 34,1\% приходились на ХДС, 7,4\% - на ХCC, что на 7,7\% больше, чем в 2009 г. Ранее добиться сопоставимого результата им удавалось лишь в 1994 г. (41,4\%). И если четыре года назад союз ХДС/ХСС завоевал на выборах в бундестаг 218 прямых мандатов, то в этот раз их количество возросло до 236. Наилучший результат по вторым голосам партии продемонстрировали в Баден-Вюртемберге, Бранденбурге, Саксонии-Ангальт, Баварии и в крупных промышленных городах (за исключением Дуйсбурга). В итоге союз ХДС/ХСС получил

\footnotetext{
106 Закон о новом регулировании распределения мест в бундестаге был принят большинством фракций 21 февраля 2013 г. и вступил в силу 9 мая 2013 г. См.: Das Wahlsystem. Bundestagswahl. URL: http://www.bundestagswahl-bw.de/wahl system1.html (дата обращения: 14.03.2013).
} 
практически половину мест в бундестаге: 311 из $631^{107}$.

Результат христианских демократов впечатлял ещё и потому, что, как правило, федеральный канцлер, который баллотируется в третий раз, испытывает определённые проблемы с имиджем - ему становится всё труднее опираться на прошлые заслуги и достижения, т.к. сказывается закономерная психологическая усталость избирателей и объективное желание перемен. В истории Германии до 22 сентября 2013 г. подобного успеха удавалось добиться лишь К. Аденауэру в 1957 г. ${ }^{108}$ на фоне холодной войны в условиях послевоенной концентрации политических партий и их разделения на правый и левый лагерь. А. Меркель привела ХДС к победе в третий раз в совсем других политических реалиях, для которых было характерно общее снижение интереса населения к выборам, более высокая конкуренция, размытость границ между традиционными партийно-политическими блоками, кризис народных партий и, как следствие, стирание программных различий между ними в восприятии граждан. С 2005 г. христианские демократы под руководством канцлерин, как было показано выше, не раз подвергали корректировке свои программные установки и политику с целью привлечь к ХДС симпатии сторонников других партий, прежде всего, своего основного соперника - СДПГ. В итоге они не только обошли конкурентов по количественным показателям в день выборов, но и добились устойчивого признания среди различных по своим политическим воззрениям и социальной принадлежности граждан, завоевав доверие в вопросах, традиционно относящихся к профессиональной сфере других партий.

Примечательно, что для тех, кто проголосовал 22 сентября 2013 г. за ХДС, компетентность её представителей и личность кандидата на пост канцлера имели практически одинаковое значение (36:38), тогда как другие избиратели ориентировались больше на компетенции и имидж партий в целом ${ }^{109}$. Для многих

107 В результате новой реформы распределения мест в бундестаге ХДС/ХСС получил 311 мандатов: из них 236 - прямые, 75 - по земельным спискам.

${ }^{108}$ К. Аденауэр избирался федеральным канцлером ФРГ в 1949, 1953, 1957 гг. 109 Quelle; Infratest dimap, Bundestagswahl in Deutschland am 22.09.2013. Viola Neu. Wahlanalyse, Konrad-Adenauer-Stiftung. S. 2. URL: http://www.kas.de/wf/ doc/kas_35530-544-1-30.pdf?131220112410 (дата обращения: 10.10.2013). 
решение поддержать своим голосом Христианско-демократический союз не было спонтанным. Согласно опросу общественного агентства «Infratest dimap», 37\% сторонников ХДС определились со своим выбором заранее, $18 \%$ опрошенных признались, что всегда голосуют за одну и ту же партию ${ }^{110}$.

СДПГ. Несмотря на неплохой старт избирательной кампании и довольно хорошие показатели опросов общественного мнения при объявлении кандидата на пост канцлера от социал-демократов, СДПГ не сумела развить свой успех дальше. В ситуации, когда большинство избирателей, независимо от своих политических симпатий, хотели видеть на посту канцлера по-прежнему А. Меркель, выбор кандидатуры П. Штайнбрюка оказался не очень удачным ${ }^{111}$. Он не только не смог реализовать связанные с ним надежды партии - объединить умеренных и левых представителей социал-демократии, привлечь на свою сторону критично настроенных избирателей из лагеря ХДС/ХСС и СвДП, но и способствовал своими непродуманными интервью и спонтанными комментариями понижению общего рейтинга СДПГ. В итоге социал-демократы выдвинули на передний план избирательной кампании программу, сосредоточив своё внимание на вопросах социальной справедливости, в которых они традиционно пользуются большей поддержкой населения, чем консервативный блок. Однако этот манёвр не смог привести СДПГ к победе. Анализ результатов опросов общественного мнения, которые отражают уровень доверия населения к партиям, позволяет сделать вывод, что и этот шаг во многом был обречён. По всем позициям (борьба с кризисом в еврозоне, создание рабочих мест, умение решать проблемы, профессионализм и т.д.) А. Меркель и ХДС значительно опережали социал-демократов, и только в вопросах социальной справедливости отставали на несколько пунктов $(26: 34)^{112}$.

${ }^{110}$ Ibid. S. 3.

111 В подобной ситуации любой кандидат от СДПГ очень сильно рисковал бы, поскольку шансов обойти А. Меркель по популярности у населения объективно было немного.

112 Если сравнить эти данные с результатами 2009 г., то уровень доверия населения к СДПГ в сфере социальной справедливости упал на 4, тогда как к ХДС возрос на 7 пунктов. Forschungsgruppe Wahlen: Bundestagswahl, 22.09. 2013. URL: http://www.forschungsgruppe.de/Aktuelles/Newsl_BTW_2013.pdf 
Таким образом, пребывая в оппозиции, СДПГ не смогла в полной мере восстановиться от поражений на предыдущих федеральных выборах 2005 и 2009 гг. и вернуть к себе доверие избирателей. В результате на выборах в бундестаг 2013 г. Социал-демократическая партия набрала 25,7\%, улучшив показатель 2009 г. лишь на 2,5\%. Не удалось социал-демократам переломить и другую отрицательную для них тенденцию - потерю первых голосов. Если в 2005 г. у них было 145, в 2009 г. - 64, то в 2013 г. -58 прямых мандатов ${ }^{113}$. Фактически у СДПГ не осталось депутатов, избранных напрямую в крупных федеральных землях. В Шлезвиг-Гольштейне и Берлине им удалось завоевать всего 2 прямых мандата, в Рейнланд-Пфальце, Бранденбурге - 1, в Баден-Вюртемберге, Баварии, Сааре, Мекленбург-Передней Померании, Саксонии, Саксонии-Ангальт и Тюрингии - ни одного. Наилучших результатов они достигли в Северном Рейн-Вестфалии - их традиционной вотчине, а также в избирательных округах Дуйсбург II, Эссен II, Бохум II, Аурих-Эмден. Наихудший результат по вторым голосам пришёлся на Саксонию. В итоге в нижней палате парламента СДПГ представляли 193 депутата.

«Левые». Партии «Левая», несмотря на потери по сравнению с выборами 2009 г. (-3,3\%), удалось обогнать «зелёных» (на $0,2 \%)$ и оказаться третьей по популярности политической силой в Германии, набрав 8,6\% вторых голосов. «Левые» получили меньше, чем рассчитывали не только по земельным спискам, но и по избирательным округам: за исключением 4 прямых мандатов в Берлине, которые они выигрывали практически всегда, 12 было потеряно - эти места перешли к кандидатам от ХДС. Сопоставление результатов опросов общественного мнения свидетельствует о том, что большинство населения воспринимали «левых» как партию, в которой отсутствует единство между лидерами и сильны внутренние противоречия ${ }^{114}$. Для ведения изби-

(дата обращения: 10.10.2013).

113 Примечательно, что П. Штайнбрюк, будучи кандидатом в канцлеры от СДПГ, проиграл в своём избирательном округе по прямым спискам мало известной представительнице ХДС. Не сумел получить прямого мандата и бургомистр столицы К. Воверайт.

114 Bundestagswahl in Deutschland am 22.09.2013. Wahlanalyse, Viola Neu, Konrad-Adenauer-Stiftung. S. 4. URL: http://www.kas.de/wf/doc/kas_35530-544-1-30. pdf?131220112410 (дата обращения: 10.10.2013). 
рательной кампании они выбрали 8 кандидатов, двое из которых, Г. Гизи и С. Вагенкнехт, представляли партию на федеральном уровне. В какой степени принятое решение способствовало улучшению имиджа «левых» и мобилизации электората, судить сложно. В любом случае, партия уверенно преодолела 5\%-ный избирательный барьер уже не в первый раз и вела активную деятельность в качестве парламентской оппозиции. И если раньше она не была готова к участию в правительственной коалиции на федеральном уровне, то в этот раз весьма отчётливо прозвучало её желание сотрудничать с СДПГ и «Союзом 90/Зелёные» ради свержения буржуазно-либерального блока.

«Союз 90/Зелёные». Партия показала довольно скромный результат, набрав 8,4\% голосов, что на 2,3\% меньше показателей 2009 г. Такой итог не только не оправдал её собственных ожиданий, связанных с этими федеральными выборами, на которых они собирались добиться минимум 15\%, но и не соответствовал потенциалу партии, особенно усилившемуся на фоне ослабления СвДП. После «Фукусимы» и «Штутгарта 21», когда немецкая общественность всерьёз задумалась об экологии и собственной энергетической безопасности, у партии появились хорошие шансы. Именно на 2011 г. пришёлся пик популярности «зелёных». Однако в ходе избирательной кампании они совершили ряд серьёзных тактических и стратегических ошибок, которыми умело воспользовались их оппоненты.

СвДП. Свободным демократам впервые с 1949 г. не удалось преодолеть 5\%-ный избирательный барьер и получить необходимое для избрания в бундестаг количество прямых мандатов ${ }^{115}$. После лучшего показателя 2009 г. (14,6\%) их доля упала до 4,8\% $(-9,8 \%)$, в итоге они оказались без представительства в нижней палате парламента ФРГ. Если четыре года назад за них голосовали не только традиционные избиратели, но и сторонники ХДС, руководствуясь желанием предотвратить повторение большой коалиции, то на этот раз данный мотив отсутствовал. С 2010 г. деятельность СвДП в правительственной коалиции население

\footnotetext{
115 При распределении мест в бундестаге учитываются лишь партии, получившие на всей территории Германии не менее 5\% вторых голосов или не менее 3 прямых мандатов. Исключение делается только для партий, представляющих национальные меньшинства.
} 
стало оценивать весьма критично, а затем и вовсе негативно. Из-за постоянных внутренних конфликтов, неспособности выполнить свои предвыборные обещания и слаженно работать в правительстве партию свободных демократов к концу легислатурного периода перестали воспринимать как функционирующую политическую силу, а её лидеры на федеральном уровне оказались мало привлекательными фигурами для избирателей. Так, деятельностью Г. Вестервелле на посту министра иностранных дел накануне выборов было довольно 49\% избирателей, кандидатом от СвДП Р. Брюдерле - 28\%, председателем партии Ф. Рёслером $-23 \%{ }^{116}$, хотя либералы - партия с самой большой долей нестабильного электората. Согласно исследованиям немецкого института «Infrates dimap», 46\% избирателей СвДП голосуют за неё из тактических соображений, 51\% выбирают из убеждённости ${ }^{117}$.

«Альтернатива для Германии» (АдГ) и другие партии. «Альтернатива для Германии» набрала 4,7\% голосов, вплотную приблизившись к границе, необходимой для избрания в бундестаг. Для столь молодой партии, которая насчитывает 16 тыс. членов, результат был весьма неплохим. Став платформой для недовольных европейской политикой А. Меркель и её курсом по спасению еврозоны, «АдГ» сумела мобилизовать т.н. пассивный электорат. Этому в немалой степени способствовала грамотная избирательная кампания лидеров партии, которые в предвыборный период привлекали к ней высокое внимание прессы. Почти $3 / 4$ сторонников партии определись со своим выбором за несколько недель до голосования. Сопоставление результатов социологических исследований, проведённых немецкими агентствами, позволяет сделать вывод, что состав избирателей данной партии не был исключительно протестным. Так, согласно данным исследовательской группы «Wahlen», 60\% опрошенных в качестве главного аргумента в пользу поддержки «Альтернативы для Германии» назвали её программу. И только 37\% признались, что голосовали за неё из-за недовольства другими парти-

\footnotetext{
${ }^{116}$ DeutschlandTREND, September 2013. S. 6.

${ }^{117}$ Bundestagswahl in Deutschland am 22.09.2013. Wahlanalyse, Viola Neu, Konrad-Adenauer-Stiftung. S. 6. URL: http://www.kas.de/wf/doc/kas_35530-544-1-30. pdf?131220112410 (дата обращения: 10.10.2013).
} 
ями ${ }^{118}$, тогда как доля протестных избирателей среди сторонников «Пиратов» составила $61 \%{ }^{119}$. Тем не менее, это не помогло им выйти из кризиса и реализовать свои амбиции на федеральном уровне - за «Пиратов» проголосовало лишь 2,2\% избирателей. Национал-демократическая партия Германии (НДПГ) набрала $1,3 \%$; праворадикальная партия «Правые» - 0,2\%. «Свободные избиратели», которые впервые участвовали в федеральных выборах, добились 1\% и тем самым получили право на государственное финансирование партии ${ }^{120}$.

\section{3. Особенности избирательной кампании}

Исторически сложилось так, что избирательные кампании в Германии на федеральном уровне долгое время отличались острой борьбой между политическими блоками вокруг наиболее важных для социально-экономического и политического развития страны вопросов. Противоположные стороны предлагали свои рецепты и альтернативные решения, выдвигая на передний план определённые (наиболее актуальные и близкие их электорату) темы. Особенно это было характерно для кампаний 1969, 1972, 1983, начала 1990-х гг. И даже выборы в бундестаг в 2002, 2005 и 2009 гг., несмотря на возросшую роль субъективного фактора, имели свои «пароли»: такими темами в 2002 г. стали война в Ираке и наводнение в Германии, в 2005 г. - борьба с безработицей и будущие социально-экономические реформы, в 2009 г. - экономический и финансовый кризис.

Избирательная кампания 2013 г. проходила в условиях явного отсутствия у большинства населения стремления к переме-

\footnotetext{
${ }^{118}$ Quelle: Forschungsgruppe «Wahlen». INFORMATIONEN zur Bundestagswahl am 22.09.2013. Ergebnis und Analyse. Verantwortlich: Thomas Volkmann, Fridrich-Naumann Stiftung. S. 18. URL: http://www.fdp-borgentreich.de/Service/Anal ysen/Graphik/fdpBRD Wahlanalyse2013FN.pdf. Данные другой исследовательской группы «Intratest dimap» отличаются от приведённых выше: 57\% опрошенных в качестве основного мотива голосования за «АдГ» указали «разочарование» в других партиях. Quelle: «Intratest dimap». Bundestagswahl in Deutschland am 22.09.2013. Wahlanalyse, Viola Neu, Konrad-Adenauer_Stiftung. S. 6. URL: http://www.kas.de/wf/doc/kas 35530-544-1-30.pdf?131220112410 (дата обращения: 10.10.2013).

119 Ibid. S. 7.

${ }^{120}$ Изначально «Свободные избиратели» планировали участвовать в выборах совместно с «Избирательной инициативой 2013», на основе которой 13 апреля 2013 г. была создана «АдГ».
} 
нам и боязни экспериментов, поэтому острой борьбы вокруг одной или нескольких доминирующих тем не возникло ${ }^{121}$. Несмотря на то, что Германия достаточно хорошо вышла из кризиса, повысилась занятость на рынке труда и немецкие граждане в основном были позитивно настроены в отношении своего будущего, у многих из них осталась тревога по поводу возможного ухудшения экономической ситуации на фоне кризиса в южноевропейских странах ${ }^{122}$. Политика правительства в отношении стран-должников, которую можно охарактеризовать как «немецкий евро-эгоизм», базирующийся на принципах: «Канцлерин лучше других знает, как сохранить наши деньги»; «Германия достаточно проявила солидарности и если она платит, значит вправе указывать, как их использовать» - совпала с мнением многих немцев. А. Меркель стала для большинства граждан тем политиком, который лучше других умеет решать проблемы и всегда контролирует ситуацию. Никто из представителей других партий в сложившейся ситуации сравниться с её популярностью не мог ${ }^{123}$. Отрыв канцлерин от её основного соперника П. Штайн-

121 Рейтинг значимости тем для избирателей согласно исследованиям группы «Wahlen»: рабочие места (25\%), уровень зарплат (18\%), кризис евро/финансовый кризис (16\%), пенсии (15\%), социальная справедливость (12\%). Quelle: Forschungsgruppe «Wahlen», Bundestagswahl in Deutschland am 22.09.2013. Wahlanalyse, Viola Neu, Konrad-Adenauer_Stiftung. S. 25. URL: http://www.kas. de/wf/doc/kas 35530-544-1-30.pdf?131220112410 (дата обращения: 10.10.2013).

122 Согласно социологическим исследованиям Алленсбахского института, в 2013 г. ухудшения экономической ситуации ожидало 26\% населения (в 2009 г. $-64 \%), 10 \%$ опрошенных волновала возможность потерять рабочее место, $68 \%$ высказали уверенность в том, что Германия хорошо подготовлена к будущим вызовам, 47\% положительно оценили современное экономическое положение (в 2009 г. таких было 9\%). Источник: Institut für Demoskopie Allenbach, «Keine Wechselstimmung». Eine Dokumentation des Beitrags von Prof. Dr. Renate Köcher in der «Frankfurter Allgemeinen Zeitung» №43 vom 20.02.2013. S. 2. URL: http://www.ifd-allensbach.de/uploads/tx_reportsndocs/Februar13_Kein e Wechselstimmung.pdf (дата обращения: 10.10.2013).

${ }^{123}$ Популярность А. Меркель на протяжении всего предвыборного периода не опускалась ниже $60 \%$, тогда как у её оппонента П. Штайнбрюка рейтинг не превышал $31 \%$. В качестве канцлера А. Меркель устраивала и значительную часть представителей оппозиционных партий, например, её были готовы поддержать 39\% «Зелёных», 43\% «левых», 60\% «АдГ», 18\% СДПГ. Интересно, что среди женщин канцлерин обошла кандидата от СДПГ по популярности на $30 \%$ (58:28), у мужчин на 10\%. Раньше такой значительной разницы по гендерному принципу не наблюдалось. Источник: Forschungsgruppe Wahlen: Bundestagswahl 22.09.2013. Blitz. URL: http://www.forschungsgruppe.de/Aktuel 
брюка на протяжении всей избирательной кампании составлял не менее 30\%. Предложить более привлекательную для населения концепцию, альтернативную курсу А. Меркель, и тем самым переломить настроение избирателей в свою пользу в условиях благоприятной для Германии экономической конъюнктуры было объективно сложно. Более того, сама канцлерин, понимая, как важно сохранить чувство стабильности у электората, сумела перенести принятие ряда значимых решений (в т.ч. о судьбе евро) на послевыборный период.

Другой важной составляющей успеха христианских демократов и личной заслугой А. Меркель стала «социал-демократизация» ХДС, которая позволила отобрать часть электората у основных конкурентов - СДПГ и «зелёных», став, таким образом, партией «середины» (центра). И хотя политику Меркель можно критиковать за отсутствие чёткой стратегической цели, частую смену приоритетов и невозможность выделить основную тему, нам представляется, как минимум одна такая цель у канцлерин всё же была - привлечь на свою сторону большинство. А. Меркель хорошо усвоила уроки предыдущих избирательных кампаний 2002 и 2005 гг. Первую ХДС проиграла СДПГ, т.к. не учла пацифистских настроений населения против войны в Ираке. Вторую удалось выиграть с весьма незначительным отрывом из-за неолиберальной экономической концепции, которая больше пугала, нежели привлекала избирателей. С тех пор А. Меркель стала учитывать мнение избирателей и принимать решения, направленные на демобилизацию её конкурентов: отказ от атомной энергетики в марте 2011 г. (удар по «зелёным»), введение минимального порога труда в отдельных областях, квота для женщин, пенсии для пожилых матерей и т.д. (нейтрализация СДПГ). Всё это позволило ХДС вернуть поддержку избирателей больших городов, которую она утратила на предыдущих выборах, а А. Меркель - побороть оппозиционные настроения внутри союза (по крайне мере до тех пор, пока она пользуется доверием населения и приносит победы).

С другой стороны, подобное преобразование ХДС приводит к стиранию границ между партиями и сближению программ, что

les/ Newsl BTW 2013.pdf (дата обращения: 10.10.2013). 
затрудняет выбор для граждан и осложняет задачу политикам, которым становится всё труднее предлагать альтернативные пути развития. Однако у христианских демократов оставалось их главное преимущество - экономическая политика. Их конкуренты вынуждены были искусственно обострять противоречия, возвращаясь к привычной схеме борьбы между блоками, и делать свои программные установки более левыми. Так произошло с СДПГ и «Союзом 90/Зелёные», которые ради достижения социальной справедливости сделали ставку в предвыборной кампании 2013 г. на увеличение налогов, чем не преминули воспользоваться христианские демократы. На фоне уже привычных спекуляций по поводу возможности создания красно-красно-зелёной коалиции они обвинили соперников в стремлении изъять у населения денежные средства и перераспределить их.

Основной удар пришёлся по «зелёным». Идея повысить налоги, в том числе на наследство (мера затрагивает не только богатых, но и практически всех граждан), отпугнула многих как традиционных сторонников партии, так и новых. Отрицательно на имидж «зелёных» повлияла и их идея ввести вегетарианский день в общественных столовых. Несмотря на то что рекомендация носила добровольный характер, она дала повод противоположному лагерю представить «Союз 90/Зелёные» партией запретов, навязывающей свои правила другим, тем более что в вопросах морали члены этой партии оказались не так уж честны. Окончательно испортить их репутацию удалось с помощью давней истории, связанной с поддержкой зелёными» в 1980-е гг. предвыборных положений, которые можно расценивать как пропаганду педофилии. В эту историю оказался замешан один из кандидатов партии Ю. Триттин ${ }^{124}$. Скандал вокруг партии и её лидера разгорелся накануне выборов и стоил «зеленым» многих голосов.

В единственный критический для ХДС момент, когда СМИ стало известно о широкой деятельности на территории Германии американских разведывательных спецслужб и предположи-

\footnotetext{
${ }^{124}$ На наш взгляд, «зелёные» напрасно оставили в тени предвыборной кампании В. Кретчмана, единственного премьер-министра от своей партии в земле Баден-Вюртемберг.
} 
тельном сотрудничестве с ними соответствующих немецких организаций, А. Меркель и её соратникам удалось продемонстрировать хорошее антикризисное управление. Они не позволили оппозиции раскачать ситуацию и дискредитировать канцлерин. Возможно, что при другой экономической конъюнктуре и настроениях избирателей, это и стоило бы ей потерянных на выбоpax голосов. Однако в условиях огромного доверия к ней населения вопрос о прослушивании немецких граждан оказался для них не столь значительным, как судьба евро. Более опасной и непредсказуемой для ХДС оказалась ситуация с её главным партнёром по коалиции и традиционным союзником - СвДП.

Как уже отмечалось выше, с самого начала избирательной кампании либералы боролись не за улучшение своего предыдущего результата, а за преодоление $5 \%$-ного барьера и сохранение за собой статуса парламентской партии. Достичь своей цели они старались двумя способами: позиционированием себя в качестве той самой политической силы, которая поможет ХДС/ ХСС остаться у власти, и обещанием не повышать налоги. На фоне общего негативного имиджа партии - постоянно спорящей, не желающей эффективно взаимодействовать с партнёрами, неспособной выполнить свои обещания (снизить налоги) и лоббирующей интересы отдельных клиентских групп, - СвДП не сумела заполнить содержательный вакуум своей программы и вернуть доверие избирателей на федеральном уровне. Консолидация бюджета, призыв к пересмотру недавно принятого, в том числе её голосами, закона об энергетике (2011 г.) не были прорывными темами и вызвали больше сомнений и вопросов, нежели доверия к компетентности партии. Возможно, свободным демократам удалось бы набрать минимум голосов, необходимый для избрания в парламент, несмотря на разочарование в них большинства населения. Немецкие избиратели привыкли к блоковому мышлению и вполне могли бы поддержать их ради победы чёрно-жёлтой коалиции, как было ранее. Однако паника, охватившая партию после поражения в Баварии, и последовавшая за этим агрессивная агитация среди сторонников ХДС за вторые голоса («Только так вы можете нас спасти!») вызвала крайне негативную реакцию у христианских демократов, кото- 
рые развернули ответную кампанию и отказали либералам в поддержке ${ }^{125}$. Проведение выборов по новой избирательной реформе, в результате которой компенсировать потери вторых голосов за счёт перевеса по прямым спискам стало невозможно, оказало определяющее влияние на принятие решения. ХДС не могла не учесть недавнего исхода выборов в Нижней Саксонии, где её традиционные избиратели поддержали вторыми голосами СвДП, что привело к проигрышу христианских демократов.

В избирательной кампании ХДС можно выделить следующие составляющие: 1) персонификация выборов и сосредоточние внимания на кандидатуре канцлера; 2) демобилизация конкурентов и использование своих сильных сторон - компетентности в вопросах экономики и внутренней безопасности (последнее не удалось); 3 ) дискредитация политических оппонентов $^{126}$. Достижение максимума голосов любой ценой - не было, на наш взгляд, главной целью ХДС. Приоритетная задача состояла в том, чтобы сохранить за собой уже имеющееся большинство. Отсюда, основой предвыборной стратегии союза стал принцип - рисковать как можно меньше, нападать по мере необходимости. Такое сочетание правильно продуманной стратегии и благоприятной конъюнктуры привело ХДС во главе с А. Меркель к убедительной победе над оппонентами.

Однако, набрав вместе с ХСС 41,5\% голосов, христианские демократы попали в сложную ситуацию: этих очень высоких показателей оказалось недостаточно, чтобы сформировать правительство большинства, а СвДП - традиционный партнёр провалилась. Создание новой коалиции оказалась трудной задачей. Ни СДПГ, имея печальный опыт взаимодействия с ХДС/ ХСС в 2005-2009 гг., ни «Союз 90/Зелёные», раздавленные поражением и стоящие перед необходимостью обновить руководящий состав и найти выход из партийного кризиса, не испыты-

125 Результаты выборов в Баварии (15.09.2013): ХДС/ХСС - 47,7\%, СДПГ 20,6\%, «Свободные избиратели» - 9\%, «Союз 90/Зелёные»- 8,6\%, СвДП - 3,3\%, «Левая» 2,1\%. Landtagswahl am 15.09.2013 in Bayern. URL: https://www.wahlre cht.de/news/2013/landtagswahl-bayern-2013.html (дата обращения: 10.10. 2013). ${ }^{126} \mathrm{~K}$ акциям дискредитации политических оппонентов наряду с упомянутым выше осуждением лидера «зелёных» Ю. Триттина можно отнести публичное обсуждение больших доходов кандидата от СДПГ П. Штайнбрюка. 
вали большого желания помочь А. Меркель. Блистательно выиграв выборы, она рисковала проиграть переговоры. После ряда зондирующих встреч с представителями обеих оппозиционных партий выбор был сделан в пользу СДПГ. Поиск компромисса затянулся надолго - коалиционные переговоры проходили в 13 рабочих группах и длились с 23 октября по 27 ноября 2013 г.

Основная проблема заключалась в том, что исполнение обещаний обеих сторон, данных ими во время выборов, требовало гораздо бо́льших расходов, чем предусматривал бюджет, тем более что ХДС изначально был против планов повысить нало$г^{127}$. Существенные разногласия между СДПГ, ХДС и ХСС возникли по следующим вопросам: пенсионная реформа; выдача двойного гражданства для иностранных граждан, рождённых на территории ФРГ; выплата пожилым матерям; дорожные пошлины; введение единой минимальной оплаты труда; разрешение браков для лиц нетрадиционной ориентации и наделение их правом на усыновление. Над сторонами всё время висела опасность срыва переговоров - до последнего было неясно, поддержат ли члены СДПГ итоговый вариант соглашения при голосования на съезде партии ${ }^{128}$. Поэтому в документ не вошло большинство спорных моментов, но приняты обтекаемые формулировки, что неизбежно должно было повлечь возвращение к спорным вопросам.

В целом выборы 22 сентября 2013 г. в бундестаг продемонстрировали, с одной стороны, сильные лидерские качества А. Меркель, которая сумела превратить ХДС в партию «середины» и привести её к убедительной победе, с другой - проблемы лидерства в остальных партиях. Сразу после поражения на выборах о своём уходе с постов заявили председатель СвДП Ф. Рёслер и кандидат от партии в предвыборной кампании Р. Брюдерле. Выводить либералов из кризиса и возвращать места в бундестаге предстояло 34-летнему К. Линднеру, который не раз поддерживал партию в кризисные моменты. Он надеялся возродить

\footnotetext{
127 По экспертным оценкам, на исполнение предвыборных обещаний новой коалиции могло бы потребоваться 50 млрд евро в год, а не 10 млрд, которые объявили её представители.

${ }^{128}$ На съезде СДПГ в Лейпциге 14 ноября 2013 г. 75,6\% социал-демократов высказались в поддержку коалиционного соглашения, 23,9\% - против.
} 
её за счёт возврата к традиционным рыночно-либеральным истокам и отказа СвДП от строгой фиксации на союзе с ХДС/ХCC ${ }^{129}$.

Представители «Союза 90/Зелёные», которые, как и либералы, рассчитывали на иной исход выборов, также пришли к выводу о необходимости произвести перемены в руководящем составе партии и выдвинуть на передний план молодых политиков. К. Рот, Р. Кюнаст, Ю. Триттин, Ш. Лемке уступили места новым лицам. Сопредседателями партии стали Симонэ Петер от левого крыла и вновь избранный Джем Оздемир - представитель т.н. «реалистов». К. Гёринг-Экхард и А. Хофрайтер продолжили руководить фракцией партии в бундестаге ${ }^{130}$. Наказанные избирателями за отход от традиционных тем, «зелёные» решили не отступать впредь от своей визитной карточки - экологии и усилить экономические аспекты в программе партии. Однако в какой последовательности следует расставить эти акценты, оказалось неясно. Часть политиков пришла к выводу, что нужно использовать поражение СвДП, чтобы привлечь на свою сторону её бывший электорат, стать более открытыми и привлекательными для бизнеса и свободных предпринимателей («Больше либерального, вместо запретов!»). Подобный шаг должен был облегчить создание в будущем возможной коалиции с ХДС/ХСС, тем более что в Гессене, где выборы в местный парламент совпали с федеральными, она стала возможной. Создание чёрно-зелёного правительства на земельном уровне в декабре 2013 г. одобрило 75\% депутатов «зелёных» и 100\% представителей фракции ХДС. Однако другая часть партии считала необходимым более серьёзно отнестись к красно-красно-зелёной опции и не исключила возможность сотрудничества с «левыми». Таким образом, одним из основных итогов парламентских выборов 2013 г. стал отказ зелёных» от строгой фиксации на традиционном для них союзе с СДПГ.

Партия «Левая», которую в пылу борьбы между привычными блоками ХДС/ХСС/СвДП и СДПГ/«Союз 90/3елёные» не

\footnotetext{
129 В декабре 2013 г. К. Линднер был избран новым председателем партии, получив $79 \%$ голосов.

${ }^{130}$ Parteigremien neu gewählt. GRUENE. URL: http://www.gruene.de/partei/partei gremien-neu-gewaehlt.html; Vorstand. GRUENE. URL: http://www.gruene-bun destag.de/fraktion/vorstand ID 4377984.html (дата обращения: 21.12.2013).
} 
принимала в расчёт ни одна из сторон, соответственно, не подверглась массированному нападению и добилась неплохих результатов. Залогом успеха, по мнению многих её членов, стала хорошая агитационная кампания кандидатов. Не умаляя заслуг Г. Гизи - признанного оратора и лидера партии, представители её левого крыла высказались за избрание сопредседателем фракции партии в бундестаге Сары Вагенкнехт, тем более что такая возможность в уставе предусмотрена.

Не удержал роль лидера и кандидат на пост канцлера от СДПГ П. Штайнбрюк, который в случае создания большой коалиции изначально исключил для себя работу в новом правительстве. В итоге вице-канцлером стал 3. Габриэль, авторитет которого среди социал-демократов заметно возрос, особенно после заключения коалиционного соглашения, которое многие представители СДПГ оценили как достижение партии и лично её председателя.

Отметим, что успех ХДС/ХСС, во многом основанный на популярности А. Меркель и высоком уровне доверия населения к её компетентности в сфере экономики и борьбы с кризисом в еврозоне, заставил остальных игроков задуматься об усилении европейской составляющей в их политике и о формировании более чёткой позиции в отношении будущего Европы. Помочь аутсайдерам этих выборов - СвДП и «Союзу 90/Зелёные» - выйти из кризиса и восстановить доверие избирателей должен возврат этих партий к традиционным ценностям и привычным для их электората темам. Другим, не менее важным итогом выборов, с точки зрения влияния на дальнейшее развитие партийно-политической системы Германии, стал отказ немецких партий от строгой фиксации на своих традиционных союзниках, что усиливает непредсказуемость результатов голосования и расширяет возможности создания коалиционных союзов в будущем.

Результаты земельных выборов 2009-2013 гг. выявили различия в развитии партийной системы в старых и новых землях. Для жителей бывшей ГДР были характерны не только более заметные электоральные симпатии к партии «левых», но и протестные настроения, которые в дальнейшем могла бы аккумулировать «Альтернатива для Германии». Если «АдГ» сумеет стать 
реальной конкурирующей с традиционными партиями силой, то это может привести к изменениям в партийно-политическом ландшафте ФРГ и сдвинуть партии в борьбе за избирателя на правый фланг.

\section{0. НЕМЕЦКАЯ ПАРТИЙНО-ПОЛИТИЧЕСКАЯ СИСТЕМА ПОСЛЕ 2013 г.}

В истории объединённой Германии немало примеров, когда её граждане руководствуются разными мотивами при выборе депутатов в бундестаг и ландтаги. Партии - победители на федеральном уровне не всегда способны закрепить свой успех на уровне земельном. Результаты избирательных кампаний 20142015 гг. подтвердили наметившиеся по итогам голосования в бундестаг тенденции: усиление позиций Христианско-демократического союза, дальнейшее ослабление либералов, рост популярности новой партии «Альтернатива для Германии». Вместе с тем их итоги выявили ряд новых тенденций в настроениях немецких избирателей и привлекли внимание исследователей к малым партиям. С одной стороны, они быстрее реагируют на изменения электоральных предпочтений, обращая внимание на проблемы, выпадающие из поля зрения народных партий, с другой - аккумулируют протестные настроения в обществе. Наиболее заметны данные тенденции в середине легислатурного периода, когда на общем фоне политической инертности может сработать т.н. «эффект вентиля», и выборы в Европарламент (ЕП) превращаются в «урок» для правящей элиты. Этим могут воспользоваться протестные партии. Избрание в ЕП популистских партий, как правило, не влияет на их поддержку на национальном уровне. Евроскептицизм редко становится достаточной опорой для избрания в местные парламенты. Выборы в федеральных землях 2014-2015 гг. оказались в этом отношении исключением - «Альтернативе для Германии» удалось попасть во все ландтаги и сенаты, в которые она баллотировалась.

\footnotetext{
Материал данной главы первоначально был опубликован в: Тимошенкова Е.П. Партийно-политическая система ФРГ после выборов в бундестаг: основные тенденции развития (2014-2015 гг.). Вестник МГИМО Университета, №5(44), 2015. С. 108-117.
} 


\section{1. Особенности и итоги выборов в Европейский пар- ламент 25 мая 2014 г.}

Выборы в Европарламент подчиняются собственной логике и следуют особым законам. Политологи отмечают их «второстепенное значение» для граждан и общественности ${ }^{131}$. В шкале приоритетов немецких избирателей они, как правило, находятся на четвёртом месте: после выборов в бундестаг, ландтаги и органы местного самоуправления. Решения национальных парламентов оказывают, по мнению немцев, большее влияние на их жизнь, чем те, которые исходят из Брюсселя. Эту тенденцию подтвердили итоги избирательных кампаний 2014 г.

Таблица 1

Важность парламентов, по мнению немецких избирателей (\%)

\begin{tabular}{|c|c|c|c|c|c|c|c|}
\hline $\begin{array}{c}\text { Важность парламентских } \\
\text { решений } \\
\text { (очень важны/важны) }\end{array}$ & 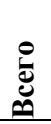 & $\begin{array}{ll}0 & 0 \\
x & x \\
x & x\end{array}$ & 态 & 气̊̊̆ & 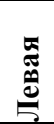 & $\frac{5}{4}$ & 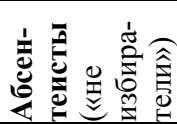 \\
\hline решения в бундестаге & 80 & 88 & 88 & 88 & 87 & 84 & 67 \\
\hline решения в Европарламенте & 59 & 61 & 66 & 72 & 63 & 66 & 46 \\
\hline решения в ландтагах & 79 & 87 & 86 & 84 & 85 & 76 & 68 \\
\hline $\begin{array}{l}\text { решения в муниципаль- } \\
\text { ных/городских советах }\end{array}$ & 76 & 83 & 84 & 79 & 78 & 66 & 65 \\
\hline
\end{tabular}

Источник: Forum Empirische Sozialforschung. Wählen, wählen, immer wieder wählen. Die Bundestagwahl und Europawahl im Vergleich. Viola Neu, Sabine Pokorny, 2014, Konrad-Adenauer-Stiftung. EV Sankt Augustin/Berlin, S. $31^{132}$.

Невысокая оценка роли Европарламента (59\%) оказывает существенное влияние на ход и итоги выборов в ЕП, определяет поведение электората и формирует свои особые законы. Как правило, активность избирателей - ниже, готовность экспериментировать - выше. Это приводит к успеху малых партий, которым нередко удаётся добиться вторых по значимости результатов. Отмена Конституционным судом ФРГ существовавшего до 2014 г. 5\%-го избирательного барьера для выборов в Европарламент усилила этот эффект и сделала возможным избрание в него партий регионального значения ${ }^{133}$.

131 В немецкой политологии термин «Second-Order-Election» используется с 1980 г. Его основоположниками считаются К. Райф и Г. Шмидт.

132 Примечание: в таблице не учитываются данные опроса сторонников СвДП, т.к. они оказались незначительными.

${ }^{133}$ С 2014 г. избирательный барьер для выборов в Европарламент составил 3\%. 
Несмотря на то что Европейский парламент обладает всеми парламентскими правами, немецкому избирателю сложно разобраться, как функционирует европейская многоуровневая система. Обычным гражданам трудно следовать во время выборов в ЕП привычной для них логике и разделять политических игроков на конфронтационные лагеря: «правительство - оппозиция». Им не понятно, как депутаты будут исполнять традиционные для них функции на наднациональном уровне и какими политическим мотивами руководствоваться при их избрании. В ходе принятия электоральных решений избирателям сложно определить уровень компетентности партий, а также оценить критерии эффективности работы их представителей в Брюсселе.

Таблица 2

\section{Результаты выборов в европейский парламент для Германии (25 мая 2014 г.)}

\begin{tabular}{|c|c|c|c|}
\hline Партия & \begin{tabular}{|l|} 
Доля го- \\
лосов, \%
\end{tabular} & $\begin{array}{c}\text { Кол-во } \\
\text { мест }\end{array}$ & Фракция Европарламента \\
\hline ХДС/ХСС & 35,3 & 34 & Европейская народная партия \\
\hline СДПГ & 27,3 & 27 & $\begin{array}{l}\text { Прогрессивный альянс соци- } \\
\text { ал-демократов }\end{array}$ \\
\hline «Союз 90/Зелёные» & 10,7 & 11 & $\begin{array}{l}\text { Зелёные/Свободный европей- } \\
\text { ский альянс }\end{array}$ \\
\hline | Жевая» & 7,4 & 7 & $\begin{array}{l}\text { Европейские объединённые } \\
\text { левые/Лево-зелёные Севера }\end{array}$ \\
\hline АдГ & 7,1 & 7 & $\begin{array}{l}\text { Европейские консерваторы и } \\
\text { реформисты }\end{array}$ \\
\hline СвДП & 3,4 & 3 & $\begin{array}{l}\text { Альянс либералов и демокра- } \\
\text { тов за Европу (АЛДЕ) }\end{array}$ \\
\hline «Свободные избиратели» & 1,5 & 1 & $\begin{array}{l}\text { Альянс либералов и демокра- } \\
\text { тов за Европу (АЛДЕ) }\end{array}$ \\
\hline |«Пираты» & 1,4 & 1 & $\begin{array}{l}\text { Зелёные/Свободный европей- } \\
\text { ский альянс }\end{array}$ \\
\hline «Партия защиты животных» & 1,2 & 1 & $\begin{array}{l}\text { Европейские объединённые } \\
\text { левые/Лево-зелёные Севера }\end{array}$ \\
\hline НДПГ & 1,0 & 1 & Вне фракций \\
\hline | Семья» & 0,7 & 1 & $\begin{array}{l}\text { Европейские консерваторы и } \\
\text { реформисты }\end{array}$ \\
\hline $\begin{array}{l}\text { Эколого-демократическая } \\
\text { партия }\end{array}$ & 0,6 & 1 & $\begin{array}{l}\text { Зелёные/Свободный европей- } \\
\text { ский альянс }\end{array}$ \\
\hline «Партия» & 0,6 & 1 & Вне фракций \\
\hline $\mid$ «Республиканцы» & 0,4 & 0 & \\
\hline $\begin{array}{l}\text { Партия верных Библии хри- } \\
\text { стиан }\end{array}$ & 0,20 & 0 & \\
\hline Прочие партии & 1,2 & 0 & \\
\hline
\end{tabular}


Источник: Zusammenfassende Tabelle. Eröffnungssitzung 2014. URL: http:// www.europarl.europa.eu/elections2014-results/de/country-results-de-2014.html ${ }^{134}$.

Выдвижение в 2014 г. общих кандидатов для европейских партий эту проблему не решило, хотя и помогло СДПГ улучшить свои результаты. Поэтому основным мотивом выбора той или иной партии в европейский парламент осталась внутренняя политика. В 2004 и 2009 гг. подобного мнения придерживалось $60 \%$, а в 2014 г. - 54\% немецких избирателей ${ }^{135}$. Говорить о наметившейся тенденции, видимо, рано. Однако если учесть возросшую явку граждан на выборы (48,1\%, что на $5 \%$ больше чем в 2009 г.), то можно констатировать некое усиление значения Европарламента для немецких избирателей и постепенное осознание ими важности принимаемых в Брюсселе решений ${ }^{136}$.

Благоприятная экономическая конъюнктура в Германии на фоне кризиса в других странах - членах ЕС, а также позитивная оценка деятельности большой коалиции способствовали хорошим результатам обеих народных партий на выборах в Европарламент. Незначительные потери союза ХДС/ХСС (-2,6\%; всего $35,3 \%$ ) объясняются просчётами в политике председателя христианских социалистов X. Зеехофера и желанием жителей Баварии преподнести своему премьер-министру «урок». СДПГ оказалась второй силой после ХДС/ХСС (27,3\%), улучшив свой предыдущий результат на 6,5\%. В немалой степени этому способствовало использование «национальной» карты - немца Мартина Шульца выдвинули общим кандидатом от европейских социал-демократов. Можно предположить, что СДПГ учла ошибки пребывания в большой коалиции в 2005-2009 гг., и в этот раз более эффективно использовала правительственные решения для поддержания своего имиджа. Результаты выборов в ЕП для партии «Левая» $(7,4 \%)$ показали, что прежняя формула «правит СДПГ, побеждают “левые”» уже не действовала. Избирательная стратегия, направленная на привлечение разочаровавшихся в

134 Eröffnungssitzung 2014. URL: http://www.europarl.europa.eu/elections2014results/de/country-results-de-2014.html (дата обращения: 14.12.2014).

${ }^{135}$ Forum Empirische Sozialforschung. Wählen, wählen, immer wieder wählen. Die Bundestagwahl und Europawahl im Vergleich. Viola Neu, Sabine Pokorny, 2014, Konrad-Adenauer-Stiftung. EV Sankt Augustin/Berlin, S. 22.

${ }^{136}$ Ibid. S. 15. 
политике СДПГ избирателей, постепенно перестала себя оправдывать. Для развития успеха и расширения электоральной базы «левым» требуются новые темы и идеи. То же самое относится и к партии «зелёных», которые сумели достичь 10,7\% (-1,4\% голосов). Потери свободных демократов (-7,6\%) подтвердили тенденцию выборов в бундестаг в 2013 г. и свидетельствовали о том, что им будет нелегко выйти из кризиса и преодолеть страх поражения. «Альтернатива для Германии», которой не хватило 0,3\% для избрания в бундестаг в 2013 г., получила в этот раз $7,1 \%$ голосов ${ }^{137}$.

10.2. Особенности и итоги выборов в ландтаги в новых федеральных землях 2014 г.

Наметившиеся в результате выборов в бундестаг и Европарламент тенденции получили развитие в ходе голосования в Саксонии (31 августа), Бранденбурге (14 сентября), Тюрингии (14 сентября). При этом каждая избирательная кампания имела свои особенности и детали. Следует отметить, что выборы проходили в новых федеральных землях, уровень жизни в которых до сих пор ниже по сравнению со старыми, а социальные проблемы острее и степень недовольства выражена сильнее. Поэтому не стоит воспринимать их итоги как общенациональную тренд.

Партия «Левая». Результаты трёх избирательных кампаний оказались для партии неплохими: в Тюрингии она получила $28,2 \%(+0,8 \%)$, в Саксонии - 18,9\% (-1,7\%), в Бранденбурге $18,6 \%(-8,6 \%)$ голосов ${ }^{138}$. Поэтому эксперты и сторонники «Левой» вернулись к обсуждению вопроса: «Способствует ли участие/стремление к участию в земельных правительствах росту популярности партии у населения?» Ответить на него однозначно по-прежнему было нельзя. В Бранденбурге присутствие «левых» в правительстве, несмотря на продолжение красно-красной коалиции, не предоставило дополнительных бонусов партии. В Саксонии вопрос так не стоял. В Тюрингии по итогам голосования «левые» оказались вторыми. Однако это не помешало их кандидату Б. Рамелов стать премьер-министром земли и

137 Eröffnungssitzung 2014. URL: http://www.europarl.europa.eu/elections2014results/de/country-results-de-2014.html (дата обращения: 14.12.2014).

${ }_{138}$ Landtagswahlen 2014. URL: http://www.wahlrecht.de/ergebnisse/index.htm (дата обращения: 14.12.2014). 
возглавить первую в истории ФРГ правительственную коалицию, состоящую из партий «Левая», СДПГ, «Союз 90/Зелёные». Красно-красно-зелёная комбинация, создания которой на федеральном уровне давно опасались буржуазно-либеральные партии, стала реальностью на уровне земельном. Долгое время, целенаправленно дискредитируя «левых» в глазах избирателей как ненадёжного партнёра, они удерживали социал-демократов и «зелёных» от этого шага, тем более что и сами «левые» с их внутренними противоречиями не были готовы к объединению. Неслучайно, федеральный канцлер и одновременно председатель ХДС А. Меркель на партийном съезде в ноябре 2014 г. публично раскритиковала партнёров по правительственной коалиции за их решение, выразив сомнение в способности СДПГ сохранить статус народной партии, заключая подобные союзы.

С другой стороны, переход сторонников «левых» на земельных выборах в лагерь «АдГ» свидетельствуют о том, что на политическом поле в вопросе мобилизации электората у них, как и у других партий, появился сильный конкурент. Долгое время именно в новых землях «Левая» служила центром притяжения для неярко выраженного диффузного протеста избирателей. В Бранденбурге от партии к «Альтернативе» ушло 20 тыс. сторонников, в Тюрингии - 16 тыс., в Саксонии - 15 тыс. $^{139}$

СДПГ и ХДС. Распространённый среди политологов тезис о том, что избиратели наказывают партии, которые правят на федеральном уровне при голосовании в местные парламенты, по итогам земельных выборов 2014 г. не нашёл чёткого подтверждения. ХДС и СДПГ удалось сохранить свои позиции там, где они традиционно были сильны. Для ХДС это подтверждают результаты выборов в Тюрингии $(33,5 \%)$ и Саксонии $(39,4 \%)$, для СДПГ - в Бранденбурге (31,9\% голосов) $)^{140}$.

В Тюрингии социал-демократов ожидали значительные потери (-6,1\% голосов по сравнению с 2009 г.), которые частично можно объяснить их позицией в отношении состава будущего

139 Wahlanalysen: Landtagswahl Brandenburg 2014, Landtagswahl Thüringen 2014, Landtagswahl Sachsen 2014. URL: http://www.forschungsgruppe.de/ Wahlen/Wahlanalysen/ (дата обращения: 24.12.2014).

140 Landtagswahlen 2014. URL: http://www.wahlrecht.de/ergebnisse/index.htm (дата обращения: 24.12.2014). 
правительства. Накануне выборов СДПГ заявила, что не исключает возможность сотрудничества с партией «левых», тогда как значительная часть населения земли отдавала предпочтение продолжению большой коалиции (48\%), а красно-красно-зелёный союз поддерживало 38\%. Сторонники СДПГ оказались расколотыми фактически поровну: 50\% выступали за создание «левого правительства», 48\% - за участие в коалиции с ХДС ${ }^{141}$. Сравнительный анализ популярности основных претендентов на пост премьер-министра Тюрингии доказывает, что кандидат от ХДС пользовался бо́льшей поддержкой у избирателей и мог рассчитывать в случае прямых выборов на 49\% голосов (+5\% сравнении с 2009 г.), представитель «Левой» - на 39\% (+7\% в сравнении с 2009 г.) $)^{142}$.

Тем не менее, социал-демократы решились на образование красно-красно-зелёного союза. Для создания коалиции с «левыми» им не хватило арифметического большинства. В итоге победитель выборов ХДС (33,5\% голосов) не только не возглавил правительство, несмотря на поддержку большей части населения, но и был вынужден перейти в оппозицию. Именно с этого времени больша́я коалиция потеряла своё преимущество в бундесрате, необходимое для принятия законов федерального значения.

На наш взгляд, данное решение СДПГ ориентировалось в большей степени на будущие выборы, нежели на предпочтения избирателей. Ослабленные пребыванием в большой коалиции в 2005-2009 гг., после участия в которой они так и не смогли вернуть доверие избирателей и достичь прежних показателей, социал-демократы предпочли объединиться с менее опытным партнёром и проверить на земельном уровне жизнеспособность и результативность союза трёх левых партий, потенциал которого, как представляется, был достаточно высок.

СвДП. С 2010 г. свободные демократы переживают тяжёлые времена, их поддержка избирателями резко упала. Апогеем за-

\footnotetext{
141 Wahlanalysen: Landtagswahl Brandenburg 2014, Landtagswahl Thüringen 2014, Landtagswahl Sachsen 2014. URL: http://www.forschungsgruppe.de/Wah len/Wahlanalysen/ (дата обращения: 24.12.2014).

142 Viola Neu. Landtagswahl Thüringen am 14.09.2014. Wahlanalyse. URL: http://www.kas.de/wf/de/33.38813/ (дата обращения: 05.10.2014).
} 
тянувшегося кризиса стали результаты выборов в бундестаг 22 сентября 2013 г., когда партия не смогла преодолеть 5\%-ный барьер $(4,7 \%)$ и впервые в своей послевоенной истории была вынуждена покинуть парламент Германии. Многие эксперты и политики увидели в её поражении на выборах в бундестаг и неспособности войти в парламенты Тюрингии, Саксонии и Бранденбурга яркое подтверждение заката этой старейшей партии и её политического конца. На наш взгляд, делать подобной вывод преждевременно. Во-первых, несмотря на неблагоприятную тенденцию свободным демократам удалось в 2012-2013 гг. войти в ландтаги Гессена, Нижней Саксонии, Северного РейнВестфалии, Шлезвиг-Гольштейна, Баден-Вюртемберга. Во-вторых, земельные выборы в новых федеральных землях не могут рассматриваться как доказательство заката либералов ещё и потому, что на востоке Германии за исключением короткого периода начала 1990-х и 2000-х гг. СвДП никогда не была сильна и репрезентативна. Например, в парламент Бранденбурга партия сумела войти лишь однажды в 2009 г., набрав 7,3\% голосов, что объясняется влиянием её успеха на федеральных выборах и обещанием снизить налоги. Тем не менее, даже тогда деятельность свободных демократов бывшие жители ГДР воспринимали в значительной степени негативно. В 2014 г. результаты партии не превысили $1,5 \%$ голосов ${ }^{143}$.

По нашему мнению, имидж СвДП в результате их пребывания в правительстве А. Меркель пострадал больше, чем либеральный бренд, т.к. их главный лозунг - сокращение налогов по-прежнему пользовался поддержкой у традиционных сторонников партии. Лидеры свободных демократов не сумели создать позитивный образ конструктивной политической силы, и были неубедительны во время предвыборной кампании, тем самым обманув ожидания своих избирателей.

Разработкой новой стратегии по выводу СвДП из кризиса руководил Н. Беер, юрист по образованию и банковский служащий. Главной задачей председателя партии К. Лиднера стало улучшение работы с прессой. Как правило, немецкие СМИ со-

143 Landtagswahlen 2014. URL: http://www.wahlrecht.de/ergebnisse/index.htm (дата обращения: 24.12.2014). 
средотачивают своё внимание на освещении деятельности партий, представленных в парламенте. В результате поражения на выборах в бундестаг свободным демократам было сложно преподносить себя в медийном пространстве.

На наш взгляд, усилия либералов, направленные на создание позитивного имиджа, должны были сопровождаться интенсивной работой над программой партии. Им не следует отказываться от темы снижения налогов. Однако без презентации продуманной стратегии во всех областях, прежде всего, в вопросах энергетики, образования, миграции, социальной сфере и отношения к ЕС настоящего убедительного обновления партии не произойдёт. Свободные демократы всегда ориентировались в большей степени на экономику, экономическая свобода стала главным лозунгом партии, морально-политические и социальные аспекты оказались на втором плане. Возможно, СвДП следует взять на вооружение и творчески осмыслить идею свободы социально незащищённого человека, большей транспарентности демократии, вопросы доступа к интернет-ресурсам и регулирования интернет-пространства. Разумное включение этих тем в программу могло бы способствовать превращению СвДП в настоящую «партию свободы».

«Зелёные». Вошли в парламенты всех трёх земель при относительно невысоких результатах избирательных кампаний чуть более необходимых 5\% голосов ${ }^{144}$. Партия испытала проблемы с мобилизацией избирателей на востоке страны. Среди прочего, это связано с отсутствием новых ярких идей и предложений, а также удовлетворённостью партийных функционеров относительной стабильностью, достигнутой на федеральном уровне. Не решил эту проблему и съезд партии, который проходил с 21 по 23 ноября 2014 г. в Гамбурге.

«Альтернатива для Германии». Продемонстрировав хорошие показатели на выборах в Европарламент, партия сумела развить свой успех и войти в парламенты всех трёх федеральных земель: в Тюрингии она набрала 10,6\%, в Саксонии 9,7\%,

\footnotetext{
144 Результаты «Союза 90/Зелёные»: Саксония 5,7\%, Бранденбург 6,2\%, Тюрингия 5,7\% Landtagswahlen 2014. URL: http://www.wahlrecht.de/ergebnisse/ index.htm (дата обращения: 24.12.2014).
} 
в Бранденбурге $12,2 \%$ голосов ${ }^{145}$. Среди создателей новой партии немало бывших членов ХДС. Поэтому эксперты и политологи рассматривали «АдГ», прежде всего, как альтернативу правительственному курсу А. Меркель, и, следовательно, как проблему христианских демократов. Однако прошедшие земельные выборы наглядно продемонстрировали, что «Альтернатива для Германии» представляет угрозу для всех партий. Особенно значительные потери сторонников пришлись на ХДС и «левых». Так к «АдГ» от Христианско-демократического союза в Саксонии ушло 33 тыс. бывших избирателей, от «левых» - 15 тыс., в Тюрингии - соответственно 18 тыс. и 16 тыс., в Бранденбурге 18 тыс. и 20 тыс. Партия «Союз 90/Зелёные» в общей сложности потеряла 5 тыс., СвДП - 46 тыс., СДПГ - 32 тыс. голосов. Удалось «Альтернативе для Германии» мобилизовать и т.н. пассивный электорат - около 40 тыс. абсентеистов поддержали в этот раз новую партию. Кроме того, на сторону «АдГ» перешло 50 тыс. избирателей от партий, которые трудно точно идентифицировать ${ }^{146}$.

Почему «Альтернативе для Германии» удалось привлечь на свою сторону не только активный электорат традиционных партий, но и т.н. пассивных избирателей?

На наш взгляд, ошибочно воспринимать «АдГ» как партию одной темы, несмотря на то, что немецкие СМИ активно формировали такой образ. Партия представила серьёзную программу по наиболее острым и важным для общества вопросам с учётом особенностей земель, в которых проходили выборы. Её лидеры - отнюдь не дилетанты в политике, а рядовые члены партии - в большинстве своём люди с хорошим образованием, достигшие положения в обществе своим трудом. Их трудно дискредитировать в глазах избирателей как неопытных и неспособных нести ответственность - черты, оказавшиеся характерными для партии «Пиратов». За «АдГ» голосуют разные социальные слои, хотя значительную часть избирателей составляют мужчи-

\footnotetext{
145 Ibid.

146 Результаты суммированы по итогам выборов в каждой федеральной земле. Wahlanalysen: Landtagswahl Brandenburg 2014, Landtagswahl Thüringen 2014, Landtagswahl Sachsen 2014. URL: http://www.forschungsgruppe.de/Wah len/Wahlanalysen/ (дата обращения: 24.12.2014).
} 
ны до 35 лет со средним образованием. Эта же возрастная группа поддерживала в своё время «Пиратов», пока те не начали работать над своей политической программой и вступать в жёсткую дискуссию друг с другом, демонстрируя разногласия.

Анализ опросов общественного мнения позволяет сделать вывод, что одним из основных мотивов в пользу голосования за «Альтернативу» стал протест по отношению к привычным «игрокам» и желание выбрать «другую» - «отличную от всех» партию. Так, например, 92\% избирателей Саксонии (в Бранденбурге - 93\%, в Тюрингии - 90\%), голосовавших за «АдГ», посчитали, что именно её политики называют проблемы своими именами, тогда как 77\% сделали выбор с целью преподнести урок другим партиям ${ }^{147}$.

На наш взгляд, «Альтернатива для Германии», как ранее «Пираты», во многом представляет проекцию нереализованных желаний и страхов избирателей, которые традиционные партии не хотят или боятся открыто обсуждать. Приставка «анти-» в программных положениях партии («антиЕвропа», «антиинтеграция», «антимиграция», «антиэтаблированные партии», за которую отдали голоса граждане, отражает наличие в немецком обществе диффузного культурного недовольства, ограничения или отсутствия альтернатив общественного развития, которые традиционные партии не обслуживают в необходимом объёме, а также отрыв политических элит от понимания интересов электората.

Другие партии. Экстремистским партиям на этих выборах успеха добиться не удалось. «Народная Партия Германии» после двух легислатурных периодов покинула парламент Саксонии, отдав «АдГ» 13 тыс. голосов ${ }^{148}$. Обеим партиям в сумме удалось аккумулировать $1 / 5$ часть избирателей Саксонии, а в некоторых округах этой земли их доля составила до 25\%. В других федеральных землях результаты данных партий незначительны.

Интересен, на наш взгляд, тот факт, что в парламент Бран-

\footnotetext{
147 Wahlanalysen: Landtagswahl Brandenburg 2014, Landtagswahl Thüringen 2014, Landtagswahl Sachsen 2014. URL: http://www.forschungsgruppe.de/Wahle n/Wahlanalysen/ (дата обращения: 24.12.2014).

148 Viola Neu, Landtagswahl in Sachsen am 31.08.2014. Wahlanalyse. URL: http://www.kas.de/wf/de/33.38698/ (дата обращения: 04.09.2014).
} 
денбурга удалось войти политическому объединению гражданской инициативы. Оно состоит из созданного бывшим депутатом от СДПГ «Бранденбургского объединённого гражданского движения», которому удалось получить прямой мандат, и партии «Свободных избирателей».

Участие населения в земельных выборах 2014 г. во всех случаях было не велико и колебалось на уровне 50\%: в Тюрингии явка избирателей составила 52,7\% (+3,5\% в сравнении 2009 г.), в Саксонии - 49,1\% (-3\%), в Бранденбурге - 47,9\% $(-19,1 \%)^{149}$. Объяснить это можно следующим образом: во всех федеральных землях накануне выборов преобладало спокойное настроение - желания сменить правительство не наблюдалось. Этому в значительной степени способствует стабильная по сравнению с другими странами ЕС экономическая ситуация в Германии и появившаяся у населения уверенность в завтрашнем дне. Например, в Саксонии накануне выборов в ландтаг, согласно опросам общественного мнения, 50\% избирателей воспринимали общее экономическое положение в стране позитивно (в 2009 г. $30 \%)$, свои личные экономические достижения - 60\% (+15\%), 74\% выразили уверенность в том, что живут лучше, чем граждане других новых земель. В Тюрингии эти показатели составили соответственно: 40\% (2009 г. - 11\%), 56\% (2009 г. - 45\%) и 56\% респондентов $^{150}$. В Бранденбурге результаты опросов общественного мнения оказались иными: жителей этой федеральной земли, как правило, отличает пессимистическое политическое настроение. Несмотря на то что половина граждан Бранденбурга (этот показатель с 2009 г. не изменился) считали, что их земля хорошо подготовлена к будущему, только $29 \%$ оценили экономическую ситуацию в стране положительно и, видимо, они же (одна треть) были уверены, что их область функционирует лучше других. При этом 60\% жителей Бранденбурга, так же как и других федеральных землей, позитивно относились к собст-

149 Wahlanalysen: Landtagswahl Brandenburg 2014, Landtagswahl Thüringen 2014, Landtagswahl Sachsen 2014. URL: http://www.forschungsgruppe.de/Wahle n/Wahlanalysen/ (дата обращения: 24.12.2014).

${ }^{150}$ Viola Neu, Landtagswahl Sachsen 2014. URL: http://www.forschungsgruppe. de/Wahlen/Wahlanalysen/, Landtagswahl Thüringen am 14.09.2014. Wahlanalyse. URL: http:/www.kas.de/wf/de/33.38813/ (дата обращения: 24.12.2014). 
венным экономическим достижениям ${ }^{151}$.

Таким образом, большинство граждан исходили из убеждения, что действующие правительства продолжат свою работу: в Саксонии - во главе с ХДС, в Бранденбурге - с СДПГ, в Тюрингии, как уже отмечалось, ожидалось продолжение большой коалиции. В подобных условиях, когда со стороны избирателей отсутствует стремление к политическим изменениям, многие из них остаются дома. Драматическое снижение интереса к выборам в Бранденбурге можно объяснить тем, что предыдущие выборы в ландтаг проходили параллельно с федеральными выборами в бундестаг, поэтому участие в выборах в 2009 г. оказалось выше. Наметившийся ранее спад интереса немецких граждан к выборам итоги избирательных кампаний 2013-2014 г. не подтвердили: на выборах в бундестаг, в земельные парламенты Гессена, Баварии, Нижней Саксонии (2013 г.) и в Европарламент (2014 г.) явка оказалась более высокой, чем в предыдущие годы.

Состоявшиеся на востоке Германии выборы обозначили новую тенденцию - отсутствие какой-либо одной приоритетной темь, способной мобилизовать избирателей. Если ранее для жителей этого региона решающее значение имел вопрос борьбы с безработицей, то в 2014 г. его важность заметно снизилась, избиратели больше волновались за будущее образовательной системы и школьную реформу. В Саксонии интерес населения к теме безработицы, которая в 2009 г. была приоритетной для 64\% граждан, в 2014 г. уменьшился до 29\%. Внимание избирателей к развитию образования и школы, напротив, возросло с 16 до $30 \%{ }^{152}$. В Тюрингии результаты опросов общественного мнения подтвердили тенденцию: для $27 \%$ опрошенных главной темой стало образование (в 2009 г. - 20\%), для 29\% - безработица (в 2009 г. - 63\%) ${ }^{153}$. В Бранденбурге создание новых рабочих мест оставалось на 1-м месте в шкале предпочтений избирателей, однако его значение для выборов по сравнению с 2009 г.

${ }^{151}$ Viola Neu, Landtagswahl in Brandenburg am 14. September 2014. Wahlanalyse. URL: http://www.kas.de/wf/de/33.38820/ (дата обращения: 04.10.2014).

152 Viola Neu. Landtagswahl in Sachsen am 31.08.2014. Wahlanalyse. URL: http://www.kas.de/wf/de/33.38698/ (дата обращения: 04.10.2014).

153 Viola Neu. Landtagswahl Thüringen am 14.09.2014. Wahlanalyse. URL: http://www.kas.de/wf/de/33.38813/ (дата обращения: 04.10.2014). 
(71\%) существенно снизилось: в 2014 г. будущее сферы образования заботило жителей этой федеральной земли также сильно $(25 \%)$, как и борьба с безработицей (30\%). И только для $10 \%$ граждан важным оказалось строительство аэропорта БерлинБранденбург ${ }^{154}$.

Результаты опросов общественного мнения в новых землях подтверждают общий федеральный тренд, который наметился в 2013 г.: снижение страхов избирателей по поводу потери рабочего места и рост значимости темы образования. Итоги земельных выборов 2014 г. выявили интересную деталь: в вопросах борьбы с безработицей граждане больше доверяют Христианско-демократическому союзу, в сфере образования - Социал-демократической партии Германии и иногда «левым». Последнее характерно для жителей Тюрингии, которые высоко оценили способность партии «Левая» защищать их интересы в области образования, поддержки семей и социальной справедливости ${ }^{155}$.

\section{3. Итоги избирательных кампаний 2015 г. в Бремене} и Гамбурге: особенности выбора «большого города»

Как правило, жители «больших городов» в Германии чаще отдают предпочтение Социал-демократической партии ${ }^{156}$. Кандидаты от ХДС традиционно испытывают трудности с мобилизацией рабочего класса. Их лидеры менее известны, им сложнее агитировать. Основное внимание СМИ уделяют представителям правящей коалиции. И если они удовлетворительно справляются со своими обязанностями, переломить данный тренд объективно сложно, решающим фактором при выборе граждан оказываются доверие к правящему бургомистру и вопросы местного значения, а не «большой политики». Соответственно, Бремен и Гамбург можно назвать таким же бастионом СДПГ, как Баварию для ХСС. Социал-демократы правят в Бремене с 1947 г. единолично (1971-1991 гг.), в Гамбурге, образуя коалиции, они

154 Viola Neu. Landtagswahl in Brandenburg am 14.09.2014. Wahlanalyse. URL: http://www.kas.de/wf/de/33.38820/(дата обращения: 04.10.2014).

155 Wahlanalysen: Landtagswahl Brandenburg 2014, Landtagswahl Thüringen 2014, Landtagswahl Sachsen 2014. URL: http://www.forschungsgruppe.de/Wahle n/Wahlanalysen/ (дата обращения: 24.12.2014).

${ }^{156}$ Имеются в виду города с численностью населения более 400-500 тыс. человек (Прим. авт.). 
ведущая политическая сила с 1946 г., за исключением небольших периодов, когда ХДС удавалось получить большинство голосов и выдвинуть своего мэра (1953-1957, 2001-2011). Эксперты неоднократно проводили социологические исследования, пытаясь объяснить причины неблагоприятного тенденции для христианских демократов в крупных городах. Однако к определённым выводам так и не пришли.

Объективно можно выделить следующие особенности: 1) значительная часть промышленных городов Германии сосредоточена на севере страны; 2) количество граждан в них, связанных с церковной общиной, меньше; 3) доля рабочих и служащих выше; 4) уровень образования горожан, как правило, выше среднего. Однако объяснить результаты голосования только экономико-географическим фактором нельзя. Количество католиков на севере и юге Германии примерно одинаковое.

Несмотря на то что СДПГ в Бремене бессменно выдвигала бургомистра из своих рядов с 1947 г., времена безмятежного правления для неё прошли. По итогам последних двух избирательных кампаний социал-демократы не могут перешагнуть рубеж в 40\% голосов. Результаты выборов 2015 г. оказались для них самыми плохими за всю историю $-32,9 \%$ голосов $^{157}$. При этом партия вышла победителем и продолжила коалицию с «зелёными». Однако рекордно низкий результат голосования заставил правящего бургомистра Й. Бёрнзена 11 мая 2015 г. уйти в отставку. Отметим, что его личная популярность среди населения оставалась на высоком уровне (63\%) и большинство избирателей хотели, чтобы он сохранил за собой пост премьерминистра земли ${ }^{158}$. Разрыв между симпатиями избирателей к лидеру социал-демократов в Бремене и поддержкой партии свидетельствует о том, что ресурс персонификации выборов, несмотря на его возросшее значение, не безграничен.

Христианско-демократическому союзу вновь удалось стать вторым, набрав $22,6 \%(+2,2 \%)^{159}$. Сравнительный анализ дове-

\footnotetext{
157 Landtagswahlen 2015. URL: http://www.wahlrecht.de/ergebnisse/index.htm (дата обращения: 21.12.2015).

158 Viola Neu. Bürgerschaftswahl in Bremen am 10. Mai 2015. Wahlanalyse. Hauptabteilung Politik und Beratung, Berlin, Februar 2015. S. 3.

${ }^{159}$ Landtagswahlen 2015. URL: http://www.wahlrecht.de/ergebnisse/index.htm.
} 
рия жителей Бремена к профессионализму партий позволяет предположить, что в будущем при благоприятной конъюнктуре ХДС может рассчитывать на бо́льшую поддержку избирателей. Социал-демократы лидировали в решении вопросов социальной справедливости и создания рабочих мест. В сфере экономической политики отставание ХДС от СДПГ было незначительно (36\%:39\%). В умении обращаться с финансами христианские демократы догнали своего соперника и демонстрировали одинаковый результат в 30\%. Следует подчеркнуть, что постепенно граждане Германии привыкли к правлению большой коалиции: её создание в Бремене были готовы поддержать 40\% избирателей, красно-зелёное правительство - 45\%. ${ }^{160}$ Как уже отмечалось выше, социал-демократы сохранили союз с «зелёными». Видимо, желание СДПГ уйти от создания большой коалиции на местах и достичь перевеса в свою пользу в бундесрате стало общефедеральной целью, к которой стремилась партия.

«Союз 90/Зелёные» не сумел повторить успех 2011 г. и потерял 7,2\% голосов, набрав $15,3 \%{ }^{161}$. На наш взгляд, это был хороший результат для партии, т.к. предыдущий высокий показатель (21\%) был связан с опасениями избирателей, вызванными катастрофой ядерного реактора в Японии. Таким образом, партия не смогла использовать своё пребывание в правящей коалиции для улучшения результата.

Настоящими и неожиданными победителями выборов оказались свободные демократы. Несмотря на неблагоприятную тенденцию 2013 г. и поражение в восточных землях в 2014 г., СвДП удалось получить $6,5 \%$ голосов $(+4,1 \%)^{162}$. Поскольку профессиональный имидж либералов вследствие их катастрофического поражения на выборах в бундестаг серьёзно пострадал, а участники предвыборной борьбы не вели дебаты вокруг одной или нескольких главных тем, можно предположить, что личная популярность кандидата от СвДП Ленке Штайнер, способство-

${ }^{160}$ Wahlanalysen: Bürgerschaftswahl in Bremen 2015, Bürgerschaftwahl in Hamburg 2015. URL: http://www.forschungsgruppe.de/Wahlen/Wahlanalysen/ (дата обращения: 21.12 .2015$)$.

161 Landtagswahlen 2015. URL: http://www.wahlrecht.de/ergebnisse/index.htm (дата обращения: 21.12.2015).

${ }^{162}$ Ibid. 
вала хорошим показателям партии, которая сплотилась вокруг своего лидера.

Свой лучший результат в Бремене продемонстрировала в этот раз партия «Левая», набрав $9,2 \%(+3,6)$ голосов ${ }^{163}$. Объяснить её успех объективными факторами сложно: доверие избирателей к компетентности партии в вопросах социальной справедливости было незначительно (12\%), так же как и доля сторонников партии, положительно оценивающих деятельность её лидера Кристины Фогт (15\%) ${ }^{164}$. Следует отметить, что «левым» удалось преодолеть впечатление «постоянно ссорящихся». Представляется, что отсутствие раскола среди членов партии и демонстрация внутреннего единства - важный фактор для немецкого избирателя.

Стремительно набиравшая популярность «Альтернатива для Германии» сумела преодолеть избирательный барьер и получила 5,3\% голосов - небольшой результат в сравнении с показателями партии в восточных землях. Частично это можно объяснить присутствием в парламенте Бремена с начала 1990-х гг. большого количества малых партий, которые благодаря раздельному 5\%-ному барьеру традиционно получают 1-2 мандата ${ }^{165}$. Для этих выборов характерна особенность: если в 2014 г. сторонники «АдГ» голосовали за неё с целью преподнести урок другим партиям, то в 2015 г. 67\% избирателей выбрали «Альтернативу» из убеждения, что Бремен не сможет принять большое количество беженцев. Эту точку зрения разделяли 79\% сторонников партии «Граждане в гневе», которая получила один мандат $^{166}$. Таким образом, вопрос о принятии беженцев приобрел большое значение для избирателей.

Несмотря на наличие в Бремене многих проблем - долги, бедность, образование - настроения сменить правительство у

\footnotetext{
163 Ibid.

164 Wahlanalysen: Bürgerschaftswahl in Bremen 2015, Bürgerschaftwahl in Hamburg 2015. URL: http://www.forschungsgruppe.de/Wahlen/Wahlanalysen/ (дата обращения 21.12.2015).

165 Это означает, что 5\%-ный избирательный барьер действует для партии только в её избирательном округе, например в порту Бремена, а не во всём городе (Прим. авт.).

166 Viola Neu. Bürgerschaftswahl in Bremen am 10. Mai 2015. Wahlanalyse. Hauptabteilung Politik und Beratung, Berlin, Februar 2015, S. 6.
} 
жителей этой земли не наблюдалось, поэтому явка, как и в других федеральных землях, оказалась невысокой - 50\% $(-5,5 \%)^{167}$.

В Гамбурге участие населения в выборах также было невелико $-56,5 \%$ (-0,8\%). Отметим, что впервые парламент ганзейского города избирали на 5 лет, а отдать голос в поддержку кандидатов могли граждане, достигшие 16 лет $^{168}$. Отсутствие мотивации участвовать в выборах можно объяснить высокой степенью уверенности гамбуржцев в завтрашнем дне и их одобрением деятельности социал-демократического правительства во главе с Олафом Шольцем. Жители Гамбурга отличаются особым оптимизмом: 84\% граждан положительно оценивали экономическую ситуацию в городе накануне выборов (62\% в 2011 г.); 78\% были довольны собственными финансовым достижениями; $81 \%$ не ожидали в будущем стагнации и только $17 \%$ опасались ухудшения ситуации (7\% в 2011 г.). Неудивительно, что при таком настроении избирателей вопросы экономической и финансовой политики не играли заметной роли при выборе. Наиболее значимыми темами для граждан Гамбурга стали ситуация с транспортом (30\%) и политика в отношении беженцев $(26 \%)^{169}$. До 2015 г. данной проблеме внимания не уделялось вовсе.

Отсутствие заметного интереса к вопросам экономики со стороны избирателей - редкое явление для Германии, так же как и широкая поддержка действующего бургомистра: $83 \%$ респондентов желали, чтобы О. Шольц продолжил свою деятельность. Вполне объяснимо, что СДПГ получила 45,6\% (-2,8\%) голосов. Вероятно, она продолжила бы править городом единолично, если бы «Альтернатива для Германии», завоевавшая 6,1\% голосов, не преодолела избирательный барьер ${ }^{170}$. Таким образом, Гамбург стал первой федеральной землёй в Германии, в парламен-

\footnotetext{
167 Земля Бремен должна федеральному бюджету более 20 млрд евро (Прим. авт.). Wahlanalysen: Bürgerschaftswahl in Bremen 2015, Bürgerschaftwahl in Hamburg 2015. URL: http://www.forschungsgruppe.de/Wahlen/Wahlanalysen/ (дата обращения: 21.12.2015).

168 Раньше парламент Гамбурга избирался на 4 года, голосовать могли граждане с 18 лет (прим. авт.).

169 Wahlanalysen: Bürgerschaftswahl in Bremen 2015, Bürgerschaftwahl in Hamburg 2015. URL: http://www.forschungsgruppe.de/Wahlen/Wahlanalysen/ (дата обращения: 21.12.2015).

${ }^{170}$ Landtagswahlen 2015. URL: http://www.wahlrecht.de/ergebnisse/index.htm.
} 
те которой представлены все 6 партий федерального масштаба.

Управлять городом СДПГ пришлось вместе с «зелёными», которые набрали $12,3 \%$ (+1\%). Следует отметить, что они единственная оппозиционная партия в Гамбурге, добившаяся позитивной оценки своей деятельности среди избирателей (по шкале от -5 до 5 «зелёные» получили 0,8 балла) ${ }^{171}$. Хороший результат продемонстрировала на этих выборах СвДП (7,1\%, $+0,8 \%)$. Ей удалось мобилизовать избирателей из лагеря народных партий: 9 тыс. сторонников ХДС и 2 тыс. СДПГ перешли к либералам. Структура электората Свободной демократической партии в Гамбурге, несмотря на огромные потери на федеральном уровне, не изменилась. Её ядро по-прежнему составляли предприниматели. ХДС потерял 6\% и оказался вторым по результатам выборов (15,9\% голосов), что подтверждает симпатии жителей промышленных городов к социал-демократам ${ }^{172}$.

До начала 1980-х гг. в партийно-политической системе ФРГ действовало правило: по итогам последних выборов можно было предсказать исход следующих. Другими словами - выборы выигрывали партии. Сегодня их чаще выигрывают кандидаты. Результаты социологических исследований подтверждают этот вывод: чем выше оценка деятельности лидера партии, тем лучше её результат. 57\% респондентов, участвовавших в социологическом опросе фонда им. К. Аденауэра в 2014 г., признали, что личность кандидата для них важнее партии. Особенно эта тенденция заметна в тех федеральных землях (например, Гамбург, Бремен, Бавария), в которых правящему премьер-министру или бургомистру удаётся сосредоточить внимание прессы на себе. В таких случаях обычно срабатывает принцип - «первым может быть только один». Другим политикам, не обладающим административным ресурсом, независимо от их компетентности, объективно сложно попасть в поле зрения СМИ и приблизится по уровню популярности, а иногда узнаваемости к действующему лидеру. Например, кандидата от ХДС в Гамбурге Д. Вериш знало 39\% избирателей, тогда как действующего бургомистра О. Шольца 79\%. Оценить деятельность лидера христи-

${ }^{171}$ Wahlanalysen: Bürgerschaftswahl in Bremen 2015... Op. cit.

172 Ibid. 
анских демократов в Бремене Е. Мотшманн смогли только 16\% респондентов $^{173}$. Другим значимым фактором в принятии решения служит ощущение стабильности. Чем больше уверенность в завтрашнем дне, тем меньше желание граждан экспериментировать. Таким образом, избиратели чаще ориентируется на кадровый состав партии и не стремятся вникать в детали их политических программ.

Итоги земельных выборов 2014-2015 гг. позволили предположить, что Христианско-демократический союз выигрывает чаще выборы в федеральных округах с меньшей плотностью населения, «Союз 90/Зелёные» и СДПГ - с большой. СвДП и «левые» такой закономерности не демонстрируют. За народные партии, как правило, голосуют представители старшего поколения, молодые и женщины поддерживают «зелёных». Мужчины со средним уровнем образования и достатка голосуют за «Альтернативу для Германии» чаще, чем интеллектуалы. «Левая» пользуется одновременно популярностью у людей с высоким и низким уровнем образования. Отметим, что партия начала играть на традиционном поле «Союза 90/Зелёные», завоёвывая всё большую популярность у служащих и предпринимателей. Учитывая её традиционный электорат (безработных), можно сделать вывод, что «левые» превратились в устойчивую политическую силу, способную мобилизовать разные слои населения. При этом «партией рабочего класса» остаётся СДПГ.

Итоги земельных выборов 2014-2015 гг. в Саксонии, Тюрингии, Бранденбурге, Бремене и Гамбурге подтвердили тенденции, наметившиеся в 2013 г.: усиление позиций Христианско-демократического союза, ослабление либералов, рост популярности «Альтернативы для Германии». Можно констатировать, что в Германии начала формироваться флюидная многопартийная система с одной ярко выраженной политической силой ХДС и другими более или менее успешными игроками. Между тем партийная система в старых и новых землях развивается по-разному, предлагая политологам для анализа различные

${ }^{173}$ В исследовании участвовало 10 избирательных округов, в которых в 2014 г. проходили коммунальные выборы. Viola Neu. Bürgerschaftswahl in Hamburg am 15.02.2015. Wahlanalyse. Hauptabteilung Politik und Beratung, Berlin, Februar 2015. S. 6. 
варианты. Для новых земель характерны не только более заметные электоральные симпатии к партии «левых», но и протестные настроения, которые в этот раз аккумулировала «Альтернатива для Германии». Не менее важным итогом выборов, с точки зрения дальнейших изменений, оказался отказ немецких партий от строгой фиксации на своих традиционных союзниках. Это подтверждает формирование в Тюрингии в октябре 2014 г. красно-красно-зелёного правительства, которое стало первой проверкой жизнеспособности этой новой для Германии опции на земельном уровне, что может привести к расширению возможностей создания коалиционных союзов в будущем и росту непредсказуемости результатов голосования, как в ландтаги, так и в бундестаг. Несмотря на то что немецкий избиратель привыкает к альянсу народных партий и всё чаще высказывается в поддержку большой коалиции, СДПГ старалась дистанцироваться от своего партнёра на федеральном уровне. Она и впредь будет стремиться избегать кооперации с ХДС там, где это возможно, в дальнейшем всё чаще решаясь на союз с «зелёными» и «левыми».

Итоги выборов в Европарламент для Германии, как и для других стран - участников ЕС, тесно связаны с внутриполитическим развитием страны. Идеи и представления о том, какой должна стать Европа в будущем, социальной и демократичной, глубоко интегрированной или децентрализованной/аморфной играли для немецкого избирателя второстепенную роль. Уверенность в завтрашнем дне и устойчивая экономическая ситуация в Германии способствовали в значительной степени победе правящего блока, курс которого поддерживало большинство населения. Такой исход выборов продемонстрировал европейским партнёрам устойчивость либерально-демократической партийно-политической системы ФРГ.

Во многих странах ЕС, в основном южноевропейских, евроскептики победили из-за недовольства местного населения диктатом Брюсселя и Берлина, принуждающего их к «жёсткой экономии». В Германии популярность «Альтернативы» можно объяснить нежеланием части немецких граждан оплачивать долги других государств. Страх перед бедностью, недовольство последствиями глобализации и капитализма привели в ФРГ к ро- 
сту популярности как правых, так и левых радикальных сил, которые критикуют ЕС с взаимоисключающих позиций. Правые недовольны чрезмерной опекой слабых государств и непозволительными тратами, требуют большей самостоятельности для участников ЕС и возможностей выхода из еврозоны. Левые выступают против исчезновения социального государства в Европе и за солидарность внутри союза. Ухудшение экономической ситуации в Европе и Германии, обострение проблемы беженцев может привести к росту радикальных настроений в немецком обществе. Эти тенденции следует учитывать народным партиям, которые должны переосмыслить свои избирательные программы и предложить в будущем населению эффективные решения назревших проблем. В противном случае рост протестных настроений усилится, а исход последующих как земельных, так и федеральных выборов станет в значительной степени непредсказуемым.

\section{2017 год - ГОД ВЫБОРОВ В ГЕРМАНИИ}

2017 г. - был годом выборов в Германии. Он начался с избрания президента ФРГ, которым стал представитель социалдемократов, бывший министр иностранных дел Ф.-В. Штайнмайер. Затем последовали выборы в ландтаги федеральных земель Саара (26 марта), Шлезвиг-Гольштейна (7 мая), Северного Рейн-Вестфалии (14 мая), в бундестаг (24 сентября), парламент Нижней Саксонии (15 октября).

\section{1. Особенности и итоги земельных выборов}

Как правило, земельные избирательные кампании считают подготовкой к главному событию - федеральным выборам. По итогам земельных выборов выявляют тенденции и судят о расстановке политических сил в целом. 2017 год можно рассматривать как исключение из правил. Во-первых, спрогнозировать

\footnotetext{
* Материал данной главы первоначально был опубликован в: Тимошенкова Е.П. «Особенности стратегии «народных партий» в избирательной кампании в бундестаг 2017 г. и формирование правительства», Германия 2017. М., 2018. С. 105-114; Тимошенкова Е.П. Успех «Альтернативы для Германии» на выборах в бундестаг 2017 г.: вызов для немецкой партийно-политической системы. Научно-аналитический вестник Института Европы РАН, 2018, №1. С. 9-15.
} 
катастрофические результаты СДПГ и значительное падение поддержки союза ХДС/ХСС было сложно, поскольку обе политические силы демонстрировали устойчивые результаты на протяжении всего года с заметным отрывом от малых партий (см. табл. 3). Лидером избирательной гонки стал Христианско-демократический союз. Ему удалось выиграть выборы в Сааре, Шлезвиг-Гольштейне и Северном Рейн-Вестфалии - впервые за период канцлерства А. Меркель христианские демократы вернули себе Киль и Дюссельдорф. Летом 2017 г. уровень их поддержки достиг $40 \%{ }^{174}$. Рейтинги СДПГ, несмотря на то, что она приходила к финишу 2-й (исключение составили выборы в Нижней Саксонии, которые социал-демократы выиграли), были стабильными, порой опережали ХДС, поэтому позволяли партии надеяться на достойный результат 24 сентября. Во-вторых, правопопулистская «Альтернатива для Германии» продемонстрировала на земельных выборах скромные результаты по сравнению с бумом 2016 г. ${ }^{175}$ Тот факт, что по итогам выборов в бундестаг она стала третьей, а на Востоке Германии второй политической силой, оказался неприятным сюрпризом для всех этаблированных партий.

Таблица 3

Итоги выборов в земельные парламенты 2017 г.

\begin{tabular}{|c|c|c|c|c|c|c|}
\hline $\begin{array}{c}\text { Федеральная земля, } \\
\text { дата выборов }\end{array}$ & $\begin{array}{c}\text { ХДС } \\
\% \\
\end{array}$ & $\begin{array}{c}\text { СДПГ, } \\
\%\end{array}$ & $\begin{array}{r}\text { «Союз 90/ } \\
\text { Зелёные», \% }\end{array}$ & $\begin{array}{l}\text { «Ле- } \\
\text { вая», \% }\end{array}$ & $\begin{array}{c}\text { СвДП, } \\
\% \\
\end{array}$ & $\begin{array}{c}\text { «дГГ», } \\
\%\end{array}$ \\
\hline Саaр, 26 марта & 40,7 & 29,6 & 4,0 & 12,8 & 3,3 & 6,2 \\
\hline Шлезвиг-Гольштейн, 7 мая & 32,0 & 27,3 & 12,9 & 3,8 & 11,5 & 5,9 \\
\hline $\begin{array}{ll}\begin{array}{l}\text { Северный Рейн-Вестфалия, } 14 \\
\text { мая }\end{array} \\
\end{array}$ & 33,0 & 31,2 & 6,4 & 4,9 & 12,6 & 7 \\
\hline Нижняя Саксония, 15 октября & 33,6 & 36,9 & 8,7 & 4,6 & 7,5 & 6,2 \\
\hline
\end{tabular}

Составлено по данным: URL: https://wahl.tagesschau.de/wahlen/2017-05-14-LTDE-NW/index.shtml (дата обращения: 15.03.2018).

Переломным моментом стали выборы в Северном РейнВестфалии. Именно они выявили серьёзные проблемы в органи-

\footnotetext{
174 Merkels Jahr war ziemlich durchwachen. URL: https://www.n-tv.de/politik/ Merkels-Jahr-war-ziemlich-durchwachsen-article20199040.html\&xid (дата обращения: 15.03.2018).

175 Подробнее анализ результатов выборов 2016 г. см: Меден Н.К. Парламентские партии против вируса популизма. В: Германия. 2016. Под ред. Белова В.Б. М., ИЕ РАН, 2017. С. 42-43.
} 
зационной работе СДПГ и слабость их кандидата на пост канцлера М. Шульца, который активно участвовал в местных избирательных кампаниях. Вероятно, после этого поражения СДПГ и долгожданной победы ХДС, А. Меркель и её соратники совершили просчёт - переоценили свои возможности, приняв слабость соперника за свою силу. Результаты этих земельных выборов подтвердили устойчивость позиции либералов и стали хорошим трамплином для развития успеха на выборах в бундестаг. Свободные демократы сумели завоевать 12,6\% голосов и вместе с ХДС сменили красно-зелёное правительство в Северном Рейн-Вестфалии. Высокий результат в этой федеральной земле символичен для СвДП: здесь родился её лидер К. Линднер, сюда он был вынужден вернуться после ухода партии с федеральной сцены и работать над её возрождением. Достижения либералов - личная заслуга К. Линднера, он стал главным действующим лицом избирательной кампании, её вдохновителем. Стратегия СвДП в 2017 г. базировалась на стремлении вернуть традиционный электорат и завоевать новый, в т.ч. протестный. Главной целью стало опередить «Альтернативу для Германии» и не позволить ей оказаться на третьем месте. СвДП заняла более жёсткую позицию по миграционному вопросу, чем ХДС, не испугавшись упреков в сближении позиций с «АДГ», предложила «вынести вопрос Крыма за скобки», сделала акцент в программе на инвестиции в науку и образование. Создание чёрножёлтого правительства (ХДС и СвДП) в Северном Рейн-Вестфалии и правительства «Ямайки» (ХДС, СвДП, «Союз 90/Зелёные») в Шлезвиг-Гольштейне могли стать примером для формирования коалиции на федеральном уровне. Вероятно, по этой причине значительная часть сторонников ХДС (1,36 млн человек) проголосовала на выборах в бундестаг за либералов ${ }^{176}$. Однако несмотря на триумфальное возвращение СвДП, предотвратить успех «Альтернативы для Германии» немецким традиционным партиям не удалось.

Блок ХДС/ХСС - формальные победители выборов в ниж-

176 Источник: Bundestagswahl 2017. Deutschland. Wählerwanderungen URL: https://wahl.tagesschau.de/wahlen/2017-09-24-BT-DE/index.shtml (дата обращения: 10.03.2018). 
нюю палату парламента ФРГ - и СДПГ получили 24 сентября 2017 г. серьёзный вотум недоверия со стороны традиционного электората, значительная часть которых поддержала «АдГ» (см. табл. 4).

Таблица 4

Итоги выборов в бундестаг 24 сентября 2017 г.

\begin{tabular}{|c|c|c|c|c|c|c|c|}
\hline Партия & 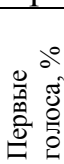 & 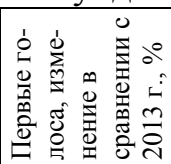 & 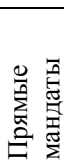 & 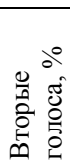 & 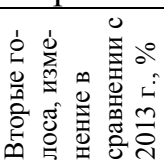 & 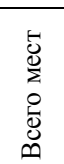 & 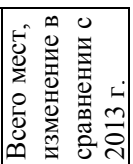 \\
\hline ХДС & 30,2 & -7 & 185 & 26,8 & $-7,4$ & 200 & -55 \\
\hline СДПГ & 24,6 & $-4,8$ & 59 & 20,5 & $-5,2$ & 153 & -40 \\
\hline АдГ & 11,5 & 9,6 & 3 & 12,6 & 7,9 & 94 & 94 \\
\hline СвДП & 7 & 4,6 & 0 & 10,7 & 6 & 80 & 80 \\
\hline Левая & 8,6 & 0,3 & 5 & 9,2 & 0,6 & 69 & 5 \\
\hline Союз90/Зелёные & 8 & 0,7 & 1 & 8,9 & 0,5 & 67 & 4 \\
\hline $\mathrm{XCC}$ & 7 & $-1,1$ & 46 & 6,2 & $-1,2$ & 46 & -10 \\
\hline
\end{tabular}

Составлено по данным: Vorläufiges Ergebnis der Bundestagswahl 2017 - Sitzverteilung. URL: https://www.wahlrecht.de/news/2017/bundestagswahl-2017.html (дата обращения: 10.03.2018).

«Альтернатива для Германии» составила конкуренцию всем партиям. Особенно сильно от её участия пострадал союз ХДС/ ХСС - от него к правым популистам ушло 980 тыс. избирателей, социал-демократы не досчитались 470 тыс. голосов, «Союз 90/Зелёные», СвДП - по 40 тыс. Партия «Левая» потеряла 400 тыс. голосов и перестала быть главной протестной силой на Востоке Германии (см. схему 1). Сразу после оглашения результатов выборов в Бундестаг А. Меркель обозначила в качестве главной задачи ХДС возвращение электората, ушедшего от партии к «АдГ» ${ }^{177}$.

\section{2. Кризис народных партий и их избирательные про- граммы}

Сближение избирательных программ двух народных партий ХДС/ХСС («За Германию, в которой мы хорошо и с удовольствием живём») и СДПГ («Пришло время для большей справедли-

\footnotetext{
${ }^{177}$ AfD-Erfolg für Merkel ein Auftrag - Seehofer sieht rechte Flanke offen. URL: https://www.welt.de/politik/deutschland/article168986876/AfD-Erfolg-fuer-Merke 1-ein-Auftrag-Seehofer-sieht-rechte-Flanke-offen.html (дата обращения: 10.02. 2018).
} 
Отток избирателей от традиционных партий в пользу «Альтернативы для Германии»

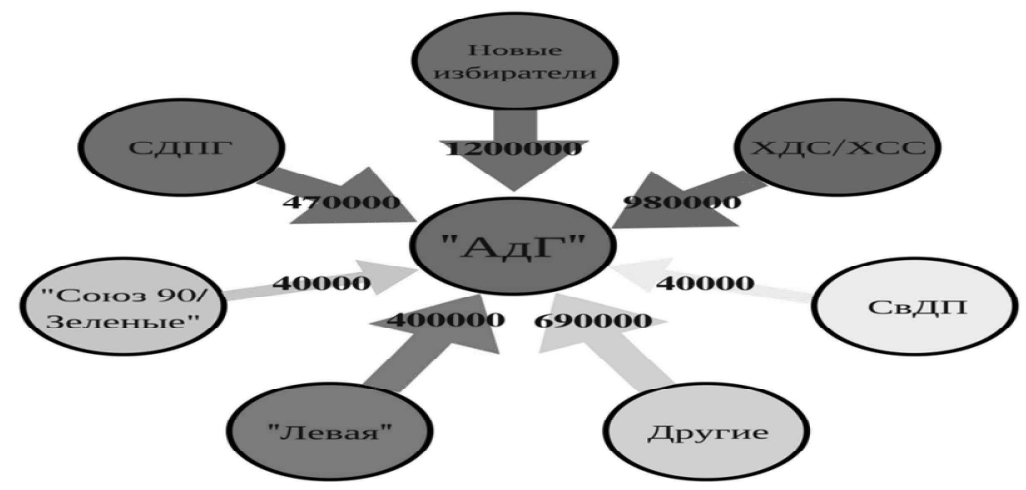

Источник: Bundestagswahl 2017. Deutschland. Wählerwanderungen URL: https:// wahl.tagesschau.de/wahlen/2017-09-24-BT-DE/index.shtml (дата обращения: 10.03.2018).

вости: обеспечить будущее, усилить Европу»), особенно заметное после их участия в федеральных и земельных правительственных коалициях, вызвали у граждан ощущение отсутствия реального выбора ${ }^{178}$. Партии обращались к одним и тем же темам и предлагали во многом схожие решения, различия в нюансах. У христианских демократов на первом месте находились вопросы развития технологий и инфраструктуры, затем - обеспечение благосостояния граждан и внешняя политика. Приоритеты СДПГ: социальная справедливость, благосостояние, инфраструктура и технологии. Обе партии уделили в этот раз значительное внимание поддержке семей. ХДС/ХСС выступила за увеличение финансовой помощи для всех, социал-демократы - в зависимости от дохода. Их поддержали малые партии: «Союз 90/Зелёные» счёл необходимым укрепить положение одиноких родителей, «АдГ» выступила против финансовой поддержки без учёта условий. Для христианских демократов брак остался главным фундаментом общества. «Левая», «СвДП», «СДПГ», «Союз 90/Зелёные»

178 Подробнее об избирательных программах партий см.: Белов В.Б. Какие перемены ждут Германию. Аналитическая записка №20(193), 2017. URL: http://www.instituteofeurope.ru/images/uploads/analitika/an93.pdf (дата обращения: 15.03.2018). 
настаивали на признании законными других форм партнёрства.

Манёвр влево для СДПГ был затруднён присутствием на партийном ландшафте «Союза 90/Зелёные» и «Левой» с ещё более «социальным» подходом к решению стоящих перед Германией проблем. Что касается ХДС, то он, стремясь завоевать «середину» и превратиться в единственную народную партию, невольно создал пространство для появления игрока справа. Отметим, что до миграционного кризиса 2015 г. немецкий электорат во многом был красно-зелёным. Эти тенденции хорошо уловила А. Меркель и встроила их в партийную программу и политический курс ХДС.

Политика «открытых дверей» для беженцев 2015 г. расколола немецкое общество и привела к усилению правых настроений, порождённых страхом, который традиционные политические силы развеять не смогли. Только две немецкие партии открыто выступили за введение предела численности беженцев (ХСС и «АдГ»). При этом «Альтернатива для Германии» единственная партия, которая отказала им в воссоединении семей. Остальные, т.е. все этаблированные партии, выступили за воссоединение семей: «Левая», «Союз 90/Зелёные», СДПГ - за беспрепятственное воссоединение, ХДС/ХСС, СвДП - при выполнении определённых условий, что означает рост численности прибывающих в Германию.

\section{3. Влияние миграционного кризиса на избиратель- ную кампанию 2017 г.: спор между ХДС и ХСС}

Меры правительства по ограничению потока беженцев и заявления ведущих политиков, в т.ч. А. Меркель, о том, что ситуация 2015 г. больше не повторится, не убедили немецких граждан в способности политического истеблишмента правильно понимать их интересы и контролировать ситуацию. Половина избирателей (55\%) были уверены, что ХДС проводит миграционную политику без учёта опасений людей. По этой причине 71\% бывших сторонников партии отвернулись от неё и не поддержали на выборах ${ }^{179}$. Существенную роль в снижении доверия

\footnotetext{
${ }^{179}$ Цит. по: «Die Republik rückt nach rechts». URL: https://www.freitag.de/autore n/benjamin-immanuel-hoff/die-republik-rueckt-nach-rechts (дата обращения: 10.02.2018).
} 
к ХДС и ХСС сыграл спор между их лидерами А. Меркель и Х. Зеехофером по вопросу введения верхнего порога численности беженцев. Ультимативный тон требований баварской партии создал у избирателей впечатление, что она готова пойти на разрыв со своим традиционным партнёром. Тем более что христианские социалисты вышли на выборы со своим программным документом - «Баварским планом», более жёстким и требовательным по вопросам миграции и интеграции, чем агитационные положения ХДС ${ }^{180}$. Этот документ, согласно заверениям идеологов партии, разрабатывался не для противопоставления общей программе союза ХДС/ХCС, а для усиления в ней акцентов. Тем не менее, закономерно возник вопрос: насколько прочен и устойчив в действительности исторический союз двух консервативных партий и может ли в будущем ХСС выступать на федеральном уровне отдельно от христианских демократов. Вопрос не праздный, поскольку одним из её главных принципов было стремление не допустить возникновения на электоральном поле более правой партии. Компромисс, достигнутый партиями в результате спора, многие восприняли как тактический манёвр.

У немецкого избирателя создалось впечатление, что партии борются не против друг друга, а за место в правительстве, которое в итоге может состоять из самых неожиданных комбинаций. Сближение подходов и замалчивание проблем приводит к эффекту оторванности политического класса от нужд населения, и, как следствие, к росту абсентеизма и/или протестного голосования. Доля абсентеистов среди немецких граждан, на выборах в бундестаг составила в 2017 г. 23,8\% ${ }^{181}$. Они могли бы стать второй по численности фракцией в нижней палате парламента. Отметим, что $61 \%$ сторонников «Альтернативы для Германии» признали, что основным мотивом их выбора стало желание преподнести правительству урок ${ }^{182}$.

\footnotetext{
${ }^{180}$ На федеральных выборах партии выступают единым блоком с общей программой (Прим. авт.).

${ }^{181}$ Wahlbeteiligung bei den Bundestagswahlen in Deutschland von 1949 bis 2017. URL: https://de.statista.com/statistik/daten/studie/2274/umfrage/entwicklung-derwahlbeteiligung-bei-bundestagswahlen-seit-1949/ (дата обращения: 10.03.2018).

${ }^{182}$ Bundestagswahl in Deutschland am 24.09.2017. Wahlanalyse von Viola Neu/ Sabine Pokorny. S. 12.
} 


\section{4. Избирательная стратегия «Альтернативы для Гер- мании» 2017 г.}

Дебаты по темам, которые не вызовут в обществе отрицательного резонанса, политическая корректность в выражении мнения в СМИ - признаки, характерные по мнению «АдГ», для партий старого типа. Отсюда, основными задачами «Альтернативы» во время выборов в бундестаг стали формирование имиджа новой партии и привлечение на свою сторону разочарованных избирателей. Представители «Альтернативы для Германии», выстраивая избирательную стратегию 2017 г., исходили из того, что доля их потенциального электората может достигнуть $20-23 \%{ }^{183}$. Предвыборная агитация «АдГ» была направлена на следующие группы граждан: 1) Протестный избиратель, недовольны оторванностью и зацикленностью этаблированных партий на себе; 2) Абсентеисты, которые следят за политическими событиями, но не участвуют в выборах, т.к. не находят для себя приемлемых предложений; 3) Социально незащищённые группы - «маленькие люди» с небольшим доходом, ориентированные на такие консервативные ценности, как порядок, патриотизм, безопасность, готовность к достижению результата, т.е. те, кто боится оказаться в проигрыше от глобализации; 4) Евроскептики - избиратели из всех социальных слоёв, которые выступают против спасения евро и создания «европейского супер-государства»; 5) Представители буржуазной середины с либерально-консервативными ценностями, недовольные миграционной политикой правительства, ростом преступности, высоким налогообложением, снижением роли традиционной семьи, проблемами в системе образования, «гендерным бредом»- уставшие от доминирования в политике красно-зелёного тренда ${ }^{184}$.

Основными принципами избирательной кампании «АдГ» стали: 1) позиционирование себя в качестве протестной силы, 2) подчёркивание профессионализма и компетентности партии в вопросах миграции, интеграции, роли ислама в Германии, без-

${ }^{183}$ Demokratie wieder herstellen. Dem Volk die Staatsgewalt zurück geben. AfD Manifest 2017. Alternative für Deutschland. Die Strategie der AfD für das Wahljahr 2017. S. 4-5.

${ }^{184}$ Ibid. S. 4. 
опасности и борьбы с преступностью, ошибок в развитии ЕС, отстаивания национальных интересов, дефицита прямой демократии и форм участия граждан в политическом процессе. «АдГ» старалась презентовать себя защитницей социально уязвимых. Стремление традиционных партий к политике «мультикультурализма» и красно-зелёный мейнстрим привели к нарушению принципа социальной справедливости. Претендовать на поддержку государства должны граждане, которые приносят пользу платят налоги, воспитывают детей, ухаживают за пожилыми. Соответственно те, кто живут в Германии давно, выражают солидарность и поддерживают стабильность в обществе, должны иметь преимущества перед вновь прибывшими в страну.

«Альтернатива для Германии» понимая, что у неё мало информационных ресурсов для презентации себя в СМИ, сделала ставку на провокационные высказывания, с помощью которых легче привлечь внимание и заставить говорить о себе. Её представители специально оказывались в центре событий, где присутствовала пресса. Политики «АдГ» осознавали, что исключение из их рядов лиц, использующих правоэкстремистскую риторику, так же, как и попытки традиционных партий включить в предвыборную агитацию некоторые требования «Альтернативы» не сделают её полноправным игроком, с которым можно пойти на заключение коалиции. Исходя из этих соображений были выработаны следующие принципы борьбы: оказываться на шаг впереди, обострять дискуссии, делать ёмкие и спорные заявления, критиковать тех, кто пытается забрать инициативу, быть готовыми к конфликту ${ }^{185}$. Такой подход к избирательной кампании заставил прессу говорить о новой партии.

Однако этаблированные партии не решились вступить с «АдГ» в жёсткий спор, опасаясь, привлечь к ней ещё больше внимания, и тем самым усилить её популярность. Итоги выборов в бундестаг свидетельствовали о том, что большинство партий не были готовы рисковать изменением своих позиций, опасаясь потерять прежние достижения. О. Лафонтен, бывший председатель «Левой», признал, что программа партии в вопросе приёма беженцев не реалистична и ошибочна (левые выступают за

${ }^{185}$ Ibid. S. 19. 
принцип открытых границ и право остаться в Германии для всех $)^{186}$. В рядах ХДС и СДПГ также звучали голоса, призывающие пересмотреть отношение к теме миграции и интеграции. Некоторые немецкие эксперты пришли к выводу, что успех «АдГ» на выборах приведёт к «поправению» республики ${ }^{187}$.

С избранием «Альтернативы» в бундестаг представительство различных социальных групп и политических взглядов в парламенте умножилось. Ей удалось сделать то, что 20 лет назад оказалось под силу лишь Г. Шрёдеру и О. Лафонтену - уменьшить социальный разрыв между избирателями, мобилизовав социально незащищённые группы населения. В сравнении с 2013 г. этот показатель уменьшился на $2,8 \%$ и составил $26,7 \%$. Активность населения в трудных районах с низкой долей участия в выборах возросла вдвое: здесь за «АдГ» проголосовало 28\% избирателей $(+18 \%)$. Поддержка этаблированных партий значительно сократилась: особенно пострадали СДПГ (-7\%) и «Левая» (-6\% голосов). Как следствие, большая коалиция в этой социальной группе представляет интересы менее четверти (22\%) граждан, обладающих правом голоса ${ }^{188}$.

«АдГ» провела успешную избирательную кампанию и на традиционном поле народных партий. В борьбе за «буржуазную середину» она завоевала дополнительные 15\% голосов. Поддержка союза ХДС/ХСС упала на $14,7 \%$ и составила в этом сегменте $37 \%$ (в 2013 г. -52\%) голосов. Он остался ведущей политической силой. Однако практически половина избирателей «буржуазной середины» либо не участвовала в выборах, либо голосовала за протестные партии: «АдГ» и «Левую» ${ }^{189}$. Таким образом, с при-

\footnotetext{
${ }^{186}$ AfD, FDP, Linke und Grüne: Opposition im Angriffsmodus. URL: https:// www.welt.de/politik/deutschland/article174440246/AfD-FDP-Linke-und-GrueneOpposition-im-Angriffsmodus.html (дата обращения: 15.03.2018).

${ }^{187}$ Die Republik rückt nach rechts. URL: https://www.freitag.de/autoren/benjaminimmanuel-hoff/die-republik-rueckt-nach-rechts (дата обращения: 10.02.2018).

${ }^{188}$ Приводятся данные исследования немецкого фонда Бертельсманна «Populäre Wahlen.Mobilisierung und Gegenmobilisierung.der sozialen Milieus bei der Bundestagswahl 2017», vom Robert Vehrkamp und Klaudia Wegschaider. S. 10. URL: https://www.bertelsmann-stiftung.de/fileadmin/files/BSt/Publikationen/Grau ePublikationen/ZD Populaere Wahlen Bundestagswahl 2017 01.pdf (дата обращения: 15.03.2018).

${ }^{189}$ Ibid. S. 12.
} 
ходом в политику «Альтернативы для Германии» борьба за средний класс обострилась, выявив проблемы народных партий.

Анализ социологических исследований, проведённых немецкими фондами, позволяет сделать вывод, что выборы в бундестаг 2017 г. обозначили появление новой конфликтной линии в партийно-политической системе ФРГ. Она проходит через всё немецкое общество, затрагивает социально-экономический срез и делит население в зависимости от отношения к традиционным ценностям на сторонников модернизации/глобализации и её противников/скептиков. Одни в силу экономических, социальных, культурных обстоятельств усматривают в модернизации угрозу для своего будущего и опасаются, что их достижения не будут признаны в эпоху цифровой экономики. Другие готовы к переменам и рассматривают их как шанс.

Если оценить итоги выборов в бундестаг с учётом новой конфликтной линии, то получается, что «Альтернатива для Германии»- единственная сила в немецкой партийно-политической системе, которая ориентируется на интересы противников модернизации: 65\% её избирателей относятся к этой группе. Самый сбалансированный состав электората у победителя выборов союза ХДС/ХСС: $52 \%$ его избирателей принадлежат к лагерю сторонников модернизации, 48\% - к противникам. В СДПГ это соотношение составляет $56 \%$ к 44\%, в СвДП - 59\% к 41\%. Лучше всего сторонников модернизации мобилизуют партии «Левая» $(62 \%)$ и «Союз 90/Зелёные» (72\%). Если бы А. Меркель удалось сформировать правительство «Ямайки» из партий ХДС/ $\mathrm{XCC}$, либералов и «зелёных», оно в большей степени представляло бы интересы сторонников модернизации и глобализации. Образование большой коалиции, с одной стороны, смягчает обозначившийся конфликт, с другой, может усилить наметившуюся тенденцию разделения электората и привести к радикализации политического процесса, как на правом, так и на левом флангах.

11.5. Избирательные стратегии народных партий 2017 г. и образование правительства

По истечении 12 лет у власти А. Меркель оказалась самым противоречивым политиком Германии, который фактически раз- 
делил страну на две половины: тех, кто за неё, и тех, кто против. Она по праву считается сильнейшим лидером, способным выживать в самых тяжёлых условиях, ловко устранять своих политических конкурентов и вовремя реагировать на настроения электората. В июле 2015 г. в СДПГ встал вопрос: имеет ли смысл выдвигать своего кандидата на пост канцлера в 2017 г., если шансов победить А. Меркель практически нет. Странный вопрос для народной партии, которая всегда претендовала на власть. Он демонстрирует, насколько устойчивым и бесспорным было лидерство канцлерин, и какой трудной, практически безнадёжной задачей казалась оппонентам победа на выборах. Миграционный кризис, последовавший в августе 2015 г., резко пошатнул позиции А. Меркель, ей грозил вотум недоверия. Сказалась объективная усталость от долгого руководства страной одним человеком и желание конкурентов взять реванш. А. Меркель, которую воспринимали гарантом стабильности Германии, оказалась уязвимой. В сентябре 2017 г. накануне выборов в бундестаг $51 \%$ имеющих право голоса считали, что три срока канцлерства для неё достаточно. Для другой половины (среди сторонников ХДС их доля составила 70\%) решающим аргументом при выборе партии стал «фактор Меркель» и её компетентность ${ }^{190}$.

На этом фоне решение социал-демократов избрать председателем СДПГ бывшего президента Европарламента М. Шульца и выдвинуть его в предвыборной кампании в качестве кандидата на пост канцлера, казалось оправданным и при определённом стечении обстоятельств могло принести успех. Риски для М. Шульца проиграть выборы были значительными, но шанс на победу был. В любом случае это решение должно было помочь политику, чья карьера в ЕС прошла наивысшую точку подъёма, достойно перейти на внутренний германский уровень и как минимум возглавить старейшую немецкую партию, пусть и в оппозиции. Выдвижение М. Шульца, который заменил непопулярного 3. Габриля, вызвало эйфорию у социал-демократов и их сторонников: впервые за долгое время в ряды партии активно начала вступать молодёжь, некоторое время СДПГ опережала

${ }^{190}$ Die Republik rückt nach rechts.URL: https://www.freitag.de/autoren/benjaminimmanuel-hoff/die-republik-rueckt-nach-rechts (дата обращения: 10.02.2018). 
своего главного соперника ХДС в рейтинге популярности, а М. Шульц догнал по этому показателю канцлерин ${ }^{191}$. Затем предвыборная гонка пошла по пройденному сценарию: успехи большой коалиции и достижения социал-демократов оказались успехами правительства А. Меркель ${ }^{192}$.

Переломным моментом стала телевизионная дуэль между кандидатами 3 сентября 2017 г. Объявленная как апогей предвыборной борьбы она разочаровала избирателей, но не потому, что канцлерин оказалась сильнее - она не изменила своим принципам и выступила как спокойный уравновешенный политик, способный сдерживать конфликты и сглаживать противоречия. Телевизионная дуль наглядно продемонстрировала слабость М. Шульца и схожесть избирательных программ двух народных партий. «Это прекрасно, что наша политика совпадает с тем, к чему также стремится СДПГ», - так можно охарактеризовать главный принцип А. Меркель в политических дебатах. Лидера СДПГ избиратели воспринимали младшим партнёром канцлерин, личные заслуги которого она ценит и уважает, но лучше знает ситуацию в стране и мире, её авторитет признают на международной арене, и только она способна принимать компетентные решения и нести за них ответственность. Приход к власти в США противоречивого и трудно предсказуемого политика Д. Трампа позволил А. Меркель презентовать себя общественности не только в качестве лидера ведущей европейской страны, но и как главную защитницу демократических ценностей Европы и Запада в целом. Противостоять её авторитету объективно было трудно. Председатель социал-демократов оказался в ситуации, когда убедительно критиковать политику правительства, в состав которого входит его партия и за действия которого несёт ответственность, сложно, а использовать антииммигрантские настроения общества - невозможно. СДПГ, в отличие от

${ }^{191}$ В СДПГ вступило более 50 тыс. новых членов.URL: http://www.faz.net/aktu ell/politik/spd-mitglieder-stimmen-fuer-grosse-koalition-15477409.html (дата обращения: 04.03.2018).

192 Подробнее об особенностях личного противостояния М. Шульца и А. Меркель в избирательной кампании 2017 г. см: Белов В.Б. Какие перемены ждут Германию. Аналитическая записка №20(93), 2017. URL: http://www.instituteof europe.ru/images/uploads/analitika/an93.pdf (дата обращения: 15.03.2018). 
ХДС/ХСС, выступает за более дружественную политику по отношению к беженцам и иммигрантам. Необходимы были прорывные идеи, которые бы из уст европейского политика звучали убедительно. Визитной карточкой М. Шульца могла стать тема Европы, которую он раскрыть не решился. Традиционная ставка СДПГ на социальную справедливость значительных бонусов принести не могла, т.к. ХДС за время правления А. Меркель сумел обрести необходимую компетентность по этому вопросу в глазах избирателей.

По ходу избирательной кампании стало очевидно, что СДПГ придёт к финишу второй. Вместе с тем М. Шульц был вынужден заявлять, что не войдёт в правительство под руководством соперницы, иначе его избирательная кампания была бы дискредитирована. Вполне объяснимо, что после провозглашения результатов выборов, которые оказались для социал-демократов рекордно низкими, он сразу заявил о переходе в оппозицию, исключив тем самым возможность участия в переговорах по созданию коалиции. С точки зрения главной задачи СДПГ (восстановления статуса полноценной народной партии: возвращения старого и завоевания нового электората, обновления имиджа), данный шаг был оправдан. С точки зрения политической мудрости и дальновидности - поспешен.

\section{6. Формирование правительства и срыв переговоров о создании коалиции «Ямайка»}

Выиграв выборы с низким результатом, А. Меркель оказалась перед трудной задачей - сформировать правительство. Желанная коалиция с СвДП необходимого количества голосов не набрала, СДПГ заявили о переходе в оппозицию, союз с партией «зелёных» арифметически оказался невозможен, любые союзы с «Левой» или «АдГ» были исключены. Фактически перед канцлерин встал выбор: формирование новой и сложной коалиции «Ямайка» (ХДС/ХСС, «Союз 90/Зелёные», СвДП); создание правительства меньшинства, зависящее от того, как будет голосовать оппозиция; или новые выборы, которые трудно спрогнозировать, и результаты которых могут повториться. Успех «АдГ» заставил все политические партии Германии задуматься о дальнейшей стратегии. С одной стороны, им необходимо 
возвращать избирателей, которые ушли на правый фланг, оттачивать свой политический имидж легче в оппозиции, с другой - выстраивать стратегию с учётом пребывания в парламенте новой право-популистской партии, известной своими провокационными заявлениями и действиями. Таким образом, высокие результаты «Альтернативы для Германии» и её присутствие в бундестаге в качестве третьей по численности фракции поставили перед традиционными политическими игроками вопрос об ответственности и формах её проявления.

Казалось, М. Шульцу удалось найти блестящий ответ: СДПГ, осознавая свою ответственность перед избирателями и демократической системой, переходит в оппозицию, чтобы не допустить в ней лидерства «АдГ». Парламентские партии автоматически получают право участвовать в рабочих группах и комитетах, входить в попечительские советы, курирующие различные сферы, в т.ч. образование и культуру, производство и науку, теле/радиовещание, рассчитывать на государственную поддержку для создания собственного партийно-политического фонда. Самая крупная оппозиционная фракция в бундестаге, согласно традициям первая отвечает на выступления представителей правительства и канцлера, возглавляет важные комитеты, например, по финансовым вопросам и внешней политике. Таким образом, роль лидера оппозиции предоставляет важные преимущества и возможности для собственного продвижения, обеспечивает внимание СМИ. Не допустить ведущей роли «АдГ» в парламенте такова была важная задача для всех партий, требовавшая координации усилий и последовательности. Поэтому переход в оппозицию мог стать для СДПГ шагом, позволяющим решать одновременно как стратегические задачи (защита партийно-демократической системы ФРГ от угрозы «справа»), так и тактические (совершенствовать программу и восстановить доверие избирателей). Однако зондирующие переговоры ХДС/ХСС с СвДП и «Союзом 90/Зелёные», на которые была вынуждена пойти А. Меркель, провалились. Дилемму немецких партий после выборов 24 сентября 2017 г. можно обозначить следующим образом: успешно бороться за электорат в оппозиции или решиться на участие в правительстве, в котором придётся идти на се- 
рьёзные компромиссы и тем самым нести имиджевые потери.

Особенность этих выборов заключалась в том, что ни одна из партий - потенциальных партнёров по коалиции с ХДС не хотела участвовать в правительстве любой ценой. Понимая сложность ситуации, в которую попала А. Меркель, представители партий ждали уступок с её стороны и дополнительных бонусов, которые позволили бы согласиться на участие в правительстве. Отказываться от своих основных предвыборных обещаний, которые обеспечили поддержку электората и были высказаны в ультимативной форме «никогда», рискованно, особенно для малых партий. Это испытали на себе либералы, потерявшие места в бундестаге в 2013 г. после участия в коалиции с ХДС/ХСС. Вернувшись, они не решились на участие в составе ещё более сложной комбинации, в которой должны были появиться «зелёные». Программные расхождения с этой партией оказались серьёзными, прежде всего, по ключевым вопросам: ограничение иммиграции, будущее ЕС и роль Германии в реформировании ЕС. Сказались опасения свободных демократов в отношении стиля управления А. Меркель, что, по их мнению, во многом способствовало разладу чёрно-жёлтой правительственной коалиции 2009-2013 г. и как следствие привело к глубокому кризису партии. Лидер СвДП К. Линднер неоднократно подчёркивал, что лучше консолидировать силы в оппозиции, чем вновь произвести на избирателей впечатление партии одержимой властью: «Конечно, СвДП хочет управлять и не боится вступать в коалицию, если в ней будут честные и корректные отношения между участниками, при которых каждый сможет внести свой вклад в проект обновления страны» ${ }^{193}$.

По признанию либералов, список противоречий между участниками в ходе переговоров увеличивался и оказался в итоге шире, чем был изначально. СвДП не захотела выступать в этом союзе «мальчиком для битья». Однако решение отказаться от участия в правительстве не вызвало ожидаемого понимания у общественности и привело к обратному эффекту. К. Линднера

\footnotetext{
${ }^{193}$ Цит. по: «Das Jahr des Christian Lindner Vom Hoffnungsträger zum Prügelknaben». URL: https://www.n-tv.de/politik/Vom-Hoffnungstraeger-zum-Pruegelkna ben-article20197868.html (дата обращения: 15.03.2018).
} 
обвинили в намеренном срыве переговоров. По мнению представителей крупного бизнеса, которые финансируют партию, интересы страны должны быть выше интересов партии ${ }^{194}$. Часть традиционного электората разочаровалась. В результате популярность либералов снизилась до 8\%. Согласно социологическим опросам исследовательского центра «Forsa», треть избирателей СвДП были готовы голосовать за другие партии, прежде всего, за не состоявшихся партнёров по коалиции - ХДС и «Сою3 90/Зелёные». Только 13\% граждан Германии продолжили доверять свободным демократам. Хуже с рейтингом доверия обстояли дела лишь у «АдГ», избиратели которой поддержали решение К. Лиднера. Он опередил по популярности лидера «Альтернативы для Германии» А. Гауланда ${ }^{195}$. Конечно, ситуация будет меняться. Однако либералов можно упрекнуть в том, что они отказались от возможности предотвратить неугодные решения правительства, не войдя в его состав. К тому же у избирателей закономерно возникнет вопрос: стоит ли голосовать за партию, которая в итоге может смалодушничать.

В результате вопрос об ответственности и как понимать её в сложившихся условиях вновь встал перед СДПГ. Германия лидирующая страна ЕС, от которой зависит вектор его дальнейшего развития, претендует на роль глобального игрока в международных отношениях. Этот статус нужно поддерживать экономически и политически. Трудная ситуация дома требует внимания и стабильного правительства, которое будет обеспечивать большинство в парламенте и тем самым бесперебойное принятие законов. Новые выборы, помимо материальных затрат из

194 Например, президент Федерального Союза немецких работодателей И. Крамер публично заявил, что К. Линднеру должно быть стыдно за то, как он себя повёл во время переговоров и уклонился от ответственности. Его поддержали и другие представители бизнеса. См.: Das Zerwürfnis Der FDP-Chef und der Arbeitgeberpräsident liefern sich einen verbalen Zweikampf. Den Ausstieg Christian Lindners aus den Jamaika-Verhandlungen nennt Ingo Kramer eine «Schande». Etliche namhafte Unternehmer sehen es ähnlich. URL: http://www. handelsblatt.com/my/politik/deutschland/die-fdp-und-die-wirtschaft-das-zerwuerf nis/20652134.html (дата обращения: 15.03.2018).

${ }^{195}$ Das Jahr des Christian Lindner Vom Hoffnungsträger zum Prügelknaben. URL: https://www.n-tv.de/politik/Vom-Hoffnungstraeger-zum-Pruegelknaben-article201 97868.html (дата обращения: 15.03.2018). 
бюджета и отвлечения сил, лучших результатов не гарантируют и могут ещё больше усилить позиции «АдГ». Потому, находясь под большим давлением общественности, СДПГ была вынуждена решиться на зондирующие переговоры о продолжении большой коалиции. Решение об участии в правительстве раскололо базис партии. Против выступил «Союз молодых социалистов», который опасался, что очередное участие в правительстве под руководством А. Меркель приведёт к утрате СДПГ «народного» статуса. Действительно, по данным социологических опросов, «Альтернатива для Германии» стала опережать по популярности социал-демократов, которые не смогли сдержать обещание о переходе в оппозицию и вынесли на публику разногласия из-за министерских портфелей ${ }^{196}$.

Камнем преткновения стал пост министра иностранных дел, который занял 3. Габриэль перед избирательной гонкой. Тогда бывшего председателя партии критиковали за единоличное и неожиданное решение, о котором большинство её членов узнало из прессы. М. Шульц, проведя избирательную кампанию для социал-демократов и трудные переговоры о создании правительства с ХДС/ХСС, оказался за бортом: он не только заявил, что не войдёт в правительство А. Меркель, но и успел отказаться от поста председателя партии в пользу А. Налес. Осознав, что проиграл, он выразил желание возглавить МИД, нарушив своё обещание, и, видимо, изначальную договорённость с 3. Габриэлем, который публично раскритиковал коллегу. В итоге М. Шульц отказался от своего намерения, но и 3. Габриэль не получил место в новом Кабинете. Таким образом, два ведущих тяжеловеса СДПГ, достигшие вершины в карьере, бывшие соратники, которые во многом определяли стратегию и тактику партии, разом утратили своё влияние и стали рядовыми депутатами бундестага: М. Шульц из-за недальновидности, 3. Габриэль из-за самонадеянности. По признанию коллег, несмотря на дипломатические способности и заслуги перед партией (он руководил ею 8 лет), единоличное принятие решений и взрывной

\footnotetext{
196 За коалиционное соглашение, согласованное между ХДС/ХСС и СДПГ 7 февраля 2018 г., проголосовало только 66\% социал-демократов. 12 марта 2018 г. партии образовали новое правительство.
} 
характер настроили против бывшего министра иностранных дел и председателя СДПГ даже его близких соратников.

Итоговое коалиционное соглашение с ХДС/ХСС 12 марта 2018 г. можно рассматривать как успех СДПГ: ей удалось отразить в соглашении около $2 / 3$ своих положений; получить шесть министерских портфелей, среди которых важный пост министра финансов, который традиционно занимает представитель партии-победителя выборов. В их ведение отошли министерства иностранных дел, труда, юстиции, семьи, природной среды. Но сможет ли партия выйти из кризиса, решившись на участие в правительстве с христианскими демократами в третий раз? Насколько прочной и управляемой будет новая коалиция? Какие риски и вызовы её ожидают?

\section{7. Шансы и риски большой коалиции: будущее народных партий.}

С одной стороны, программные воззрения ХДС/ХСС и СДПГ во многом совпадают, в предыдущих двух коалициях партии работали слаженно, они осознают свою ответственность перед избирателями и не будут рисковать из-за опасения новых выборов. С другой стороны, СДПГ необходимо вернуть симпатии избирателей. В результате лидеры партии заявили о необходимости ясной и жёсткой линии в правительстве, что предполагает не только острую критику, но и готовность к решительным действиям. Позиции А. Меркель, которая стала канцлером Германии в 4-й раз, ослабли. Ей необходимо было работать над укреплением поддержки внутри собственной партии, в рядах которой было достаточно недовольных и ожидающих подходящего момента, чтобы её сместить. Понимая сложность ситуации, канцлерин пошла на уступки: Х. Зеехофер (ХCC), главный критик её миграционного курса, получил пост министра внутренних дел. Решение А. Меркель отдать портфель министра здравоохранения Й. Шпану (ХДС) - шаг навстречу оппозиции в рядах собственной партии. Однако для выражения вотума недоверия необходим новый лидер, за которого проголосуют $2 / 3$ депутатов. Спрогнозировать, сумеет ли большая коалиция продержаться весь легислатурный период до 2021 г. сложно.

Камнем преткновения для нового правительства может стать 
миграционная политика и вопросы поддержи безработных и социально незащищённых слоёв населения, особенно обострившиеся на фоне притока беженцев, обеспечение и интеграция которых требует значительных средств. Проблема немецких партий (участвующих в правительстве и оппозиционных) заключается в том, что значительная часть электората привыкла жить в социальном государстве и боится утратить свои преимущества в пользу иммигрантов и беженцев. В то же время большинство партий, в т.ч. ХДС и СДПГ, не готовы к жёстким мерам по ограничению иммиграции, которых от них требует «АдГ».

Вопросы внутренней политики Германии тесно связаны с будущим ЕС. Возможность проводить социальные программы обеспечивает экспортно-ориентированная экономика ФРГ, что нравится далеко не всем странам - членам ЕС и создаёт проблемы. Несмотря на попытки Италии совместно с Францией добиться от Германии реформ еврозоны, вероятность выхода Италии из «евро» представляется аналитикам вполне реальной. Структурные проблемы в экономике этой страны, победа на выборах правых сил - предупреждение для доминирующей в ЕС Германии, которая должна решиться на реформирование союза вместе с Францией, пока популистский бунт в Риме не поразил всю Европу. Для проведения реформ оба лидера должны прийти к компромиссу: Германия - пересмотреть свою догму о необходимости политики строгой экономии и осознать, что политика «открытых дверей» для иммигрантов раскалывает Европу, а Франция - отказаться от нереалистичных требований к Германии по созданию «трансферного союза». Выработать чёткую линию реформирования еврозоны и решиться на совместные действия с Парижем главе правительства А. Меркель в союзе с социал-демократами будет легче, несмотря на сопротивление оппозиции и части собственной партии.

Создание большой коалиции не обещает значительных изменений в российско-германских отношениях, хотя отношения с Россией будут более предсказуемы и последовательны. Тот факт, что МИД остался за СДПГ, позволяет надеяться на прагматичный подход нового правительства в вопросах экономического сотрудничества и диалога гражданских обществ. Оба по- 
ложения нашли отражение в коалиционном договоре.

Итоги выборов в бундестаг для Германии тесно связаны с национальными партийно-политическими тенденциями. Основным мотивом в принятии решений для избирателей стали компетентность партий в вопросах внутренней политики и их способность отстаивать немецкие интересы в Европе. Уверенность в завтрашнем дне большинства населения, несмотря на большой приток беженцев, устойчивая экономическая ситуация в Германии по сравнению с другими европейскими странами, хороший внешнеполитический имидж страны и отсутствие лидера, способного составить конкуренцию А. Меркель, способствовали в значительной степени победе консервативного блока ХДС/ ХCС. Однако позиции канцлерин по сравнению с предыдущими периодами значительно ослабли: недовольство её политикой и стилем управления усилились как среди населения (каждый второй немец считает, что она должна покинуть свой пост до окончания легислатурного периода ${ }^{197}$ ), так и внутри партии. Сумеет ли она сохранить свои лидирующие позиции в последующие четыре года - вопрос сложный. Этот срок канцлерства станет для неё последним. А. Меркель придётся пойти на уступки собственной оппозиции, что повлечёт за собой кадровые перестановки в ХДС и дебаты о программном обновлении партии.

Вопросы лидерства, обновления стратегии и политического курса партии будут волновать и социал-демократов. Они пострадали сильнее, чем союз ХДС/ХСС, от участия в больших коалициях и выхода на политическую арену нового игрока - «Альтернативы для Германии». Партии придётся бороться за свой «народный статус» и доказывать избирателям, что она может быть не только младшим партнёром ХДС/ХСС в правительстве, но и определять его работу. Такой подход требует новой стратегии и более решительных действий, что чревато правительственными кризисами. Раскол в партии из-за необходимости снова участвовать в коалиции под руководством А. Меркель оказался очень глубоким.

\footnotetext{
${ }^{197}$ Da dämmert was. Merkels Jahr war ziemlich durchwachsen. URL: https://www. n-tv.de/politik/Merkels-Jahr-war-ziemlich-durchwachsen-article20199040.html (дата обращения: 15.03.2018).
} 


\section{2. ФОРМУЛА ВЛАСТИ А. МЕРКЕЛЬ}

А. Меркель - политический долгожитель, её стремительная и неожиданная для многих карьера - результат не только внутриполитического развития Германии после объединения, но и феномен, выходящий за пределы немецкого государства. Первая женщина канцлер, первая глава правительства ФРГ с «гэдээровским» прошлым, признанный лидер ЕС, авторитетный политик международного уровня. Она четыре раза подряд становилась канцлером, 18 лет возглавляла самую сильную немецкую политическую партию ХДС, успехи которой были и остаются во многом её личной заслугой, впрочем, как и поражения.

Секрет формулы успеха «железной канцлерин» пытаются объяснить многие. Физик по образованию, она умеет просчитывать ситуации и прорабатывать в уме множество различных сценариев, обладает огромным терпением и, по мнению критиков, медлительна в принятии решений. Она ждёт, когда неприемлемые варианты отпадут сами собой, а политические конкуренты устанут и совершат ошибку. По признанию самой А. Меркель, оставаться на протяжении 13 лет главным человеком в государстве ей помогало совмещение постов канцлера и председателя партии. Именно сосредоточение этих двух функций в одних руках позволяет наиболее эффективно управлять страной: контролировать благодаря поддержке партии нижнюю палату парламента, тем самым способствуя принятию законов, которые разрабатывает возглавляемое ею правительство. К тому же пост председателя партии обеспечивает надёжный тыл - чтобы сместить канцлера до выборов, ${ }^{2} / 3$ депутатов бундестага должны договориться о кандидатуре нового лидера, который без поддержки однопартийцев действующего главы правительства не сможет набрать необходимое количество голосов для выражения вотума недоверия. Провести такую операцию за спиной канцлера - председателя партии довольно сложно.

\footnotetext{
Материал был первоначально опубликован в: Тимошенкова Е.П. Формула власти А. Меркель: почему канцлерин отказалась от поста председателя партии ХДС. Экономика и политика Германии: через год после выборов. Отв. ред. Е.П. Тимошенкова. М., ИЕ РАН, 2019. С. 49-56.
} 
Совмещение двух постов - главы правительства и партии не было личным открытием А. Меркель. Этот вариант использовали и другие лидеры Германии, например, бывший председатель СДПГ Г. Шрёдер. Сама А. Меркель не раз признавалась журналистам, что именно политическое падение её предшественника произвело на неё сильное впечатление и стало уроком. По мнению А. Меркель, деградация авторитета канцлерской власти Г. Шрёдера началась с его отказа от поста председателя партии изза дебатов по поводу принятия социал-демократами непопулярной у населения программы «Повестка дня 2010». По этой причине заявление А. Меркель 29 октября 2018 г. о том, что она не будет выдвигать свою кандидатуру на пост председателя ХДС на следующем съезде партии, прозвучало как политическая сенсация $^{198}$. Между тем сама канцлерин подчеркнула, что намерена возглавлять правительство до окончания легислатурного периода ${ }^{199}$.

Для тех, кто внимательно следит за выступлениями канцлерин, заявление о том, что она возглавляет правительство ФРГ в последний раз, сюрпризом не стало. В беседах с журналистами А. Меркель как-то призналась, что политикой должны заниматься профессионалы, и 10 лет - это наиболее эффективный и оптимальный срок для политической карьеры на высшем государственном уровне ${ }^{200}$. По истечении этого времени трудно удерживать авторитет, поэтому уходить нужно во время и, следуя её логике, добровольно. Однако, несмотря на эти рассуждения, А. Меркель удаётся быть первой дольше. Накануне выборов в бундестаг в сентябре 2017 г. она пообещала избирателям, что в случае победы ХДС, этот срок канцлерства станет для неё последним.

Что же заставило «тефлоновую леди» спустя год после победы на выборах принять столь рискованное, с её точки зрения, решение - отказаться от принципа совмещения двух должностей:

\footnotetext{
198 Съезд партии ХДС состоялся 7 декабря 2018 г. в Гамбурге.

${ }^{199}$ Merkel will nicht mehr für Parteivorsitz kandidieren. URL: http://www.spiegel. de/politik/deutschland/cdu-angela-merkel-will-nicht-mehr-fuer-parteivorsitz-kandi dieren-a-1235646.html (дата обращения: 20.12.18).

${ }^{200}$ Nikolaus Blome. Angela Merkel - Die Zauderkünstlerin. Pantheon Verlag, München 2013. S. 51.
} 
правительственной и партийной? Сможет ли она, не будучи председателем ХДС, оставаться на посту канцлера, не опасаясь бунта в рядах собственной партии? И почему она выступила с этим заявлением 29 октября 2018 г.?

Причин, побудивших А. Меркель принять такое решение, несколько. Главная, на наш взгляд, - кризисное состояние правительства, которое она возглавляет. Канцлерин честно признала, что то, как работает большая коалиция в Берлине, неприемлемо. Правительство находится в кризисе со своего формирования. И хотя управлять коалицией, состоящих из партий ХДС, $\mathrm{XCC} \mathrm{и} \mathrm{СДПГ,} \mathrm{для} \mathrm{А.} \mathrm{Меркель} \mathrm{привычное} \mathrm{дело,} \mathrm{отличительной}$ особенностью нового кабинета стало не столько вынужденное участие партнёров (создание больших коалиций - всегда вынужденный шаг для двух народных партий ХДС/ХСС и СДПГ), сколько обречённость на принятие решения о формировании правительства. Результаты федеральных выборов 2017 г. в нижнюю палату германского парламента оказались для этих партий гораздо ниже ожидаемых. Учитывая популярность правопопулисткой партии «Альтернатива для Германии», их можно рассматривать, как вотум недоверия избирателей к прошлому правительству.

За время пребывания у власти А. Меркель оказалась самым противоречивым политиком. Решение о приёме большого количества беженцев в Германии раскололо немецкое общество и способствовало росту популярности правопопулисткой «Альтернативы для Германии», которая отобрала голоса у других партий, чем повергла их в шоковое состояние и вынудила начать пересматривать свои программы и стратегии. Восстанавливать доверие избирателей легче в оппозиции - не надо нести ответственность за непопулярные решения правительства. Провал первого раунда переговоров о создании коалиции с СвДП и «зелёными» грозил немецким партиям новыми выборами, результаты которых могли значительно ослабить их прежние позиции и усилить «АдГ». Для Германии такая нестабильность в вопросе управления могла превратиться в раздражающий фактор, последствия которого трудно просчитать и контролировать с учётом тенденции поправения настроений электората. Необходи- 
мость постоянно отвлекаться на решение проблем внутри страны ослабляла позиции Германии на международной арене и могла привести к утрате лидерства в ЕС. Вероятно, А. Меркель пришла к выводу, что слабое правительство лучше, чем никакое, и решилась заключить компромиссное коалиционное соглашение, состоящее из уступок как социал-демократам, так и партии - союзнику ХСС.

Коалиционное соглашение от 12 марта 2018 г. спустя шесть месяцев после выборов превратилось в пороховую бочку для её участников. Главным разжигателем конфликтов стал бывший союзник А. Меркель, председатель баварской партии ХСС Х. Зеехофер, который активно критиковал миграционную политику канцлерин до и во время выборов в бундестаг. Войдя в состав правительства в качестве министра внутренних дел, Х. Зеехофер начал использовать своё назначение не только для того, чтобы вносить коррективы в правительственный курс по вопросу приёма беженцев, но и для решения своих личных задач. Как глава партии ХСС, которой в сентябре 2018 г. предстояли земельные выборы в Баварии и борьба за электорат с правопопулистской «АдГ», он сделал ставку на ужесточение миграционного законодательства и решил показать, «кто в доме хозяин». Разногласия между политиками достигли апогея в начале июля, когда X. Зеехофер поставил А. Меркель ультиматум и дал ей для нахождения компромисса всего две недели. Острота спора и предмет разногласий (речь шла о высылке на границе Германии беженцев, которые уже зарегистрировались в других государствах ЕС) продемонстрировали, на наш взгляд, что главной движущей силой действий и заявлений баварского политика было желание поколебать авторитет А. Меркель и, вероятно, приблизить окончание её политической карьеры, как канцлера. Разлад в коалиции повредил имиджу ХСС, она не сумела одержать внушительную победу на выборах в Баварии, потеряв много голосов в пользу «Союза 90/Зелёные» и «АдГ» ${ }^{201}$.

${ }^{201}$ ХСС набрала на выборах в Баварии 37,2\% голосов, потеряв 10,4 процентных пункта. Landtagswahl 2018 in Bayern - Vorläufiges Ergebnis. URL: https:// www.wahlrecht.de/news/2018/landtagswahl-bayern-2018.html\#absolut (дата обращения: 20.12.18). 
Фактически работа правительства с его образования проходила по одному сценарию: сначала жёсткий спор между традиционными союзниками ХДС и ХСС, поиск компромисса между ними, затем угроза выхода из коалиции со стороны их партнёра социал-демократов, которых не устраивает отход от коалиционного договора и обсуждение нового решения без их участия. А. Меркель из эффективного менеджера превратилась в «пожарного». Каждый новый конфликт, который разгорался между участниками правительственной коалиции, мог привести к её распаду. Вероятность того, что Меркель удастся сохранить за собой канцлерство до 2021 г., оказалась зыбкой. Выступая 29 октября 2018 г. перед коллегами по партии, А. Меркель призналась, что решение не выдвигать свою кандидатуру на пост председателя ХДС, она приняла ещё летом, однако надеялась объявить об том позже. Причиной, побудившей сделать заявление раньше, стали низкие результаты ХДС на земельных выборах в Гессене ${ }^{202}$. Падение популярности партии среди избирателей результат влияния правительственного кризиса в Берлине, который А. Меркель не удалось преодолеть. Этот шаг, с одной стороны, продемонстрировал обществу, что она осознаёт ответственность за снижение популярности партии, которую возглавляет, с другой - понимает: сложности с коалицией, которая может распасться в любой момент, требуют от неё повышенного внимания к своим первоочередным обязанностям главы правительства.

Спорная миграционная политика, курс ХДС на завоевание политического центра общества, приведший к её социал-демократизации и отходу от традиционных консервативных ценностей, единоличные и неожиданные для базиса партии решения, особый стиль управления и объективная психологическая усталость от руководства А. Меркель привели к росту недовольства внутри Христианско-демократического союза. Пока партия убедительно выигрывала выборы, ей удавалось контролировать внутреннюю оппозицию и сдерживать возмущение. Отказав-

202 ХДС набрала на выборах в Гессене 26,9\% голосов, потеряв 11,35 процентных пункта. Landtagswahl 2018 in Hessen -Vorläufiges Ergebnis. URL: https:// www.wahlrecht.de/news/2018/landtagswahl-hessen-2018.html (дата обращения: 20.12.18). 
шись от поста председателя партии и подтвердив публично, что четвёртое канцлерство станет для неё последним, А. Меркель предприняла попытку успокоить внутреннюю оппозицию среди христианских демократов. Другой её задачей стало - повлиять на выбор преемника, пока она ещё обладает авторитетом и остаётся канцлером. И ей это удалось. В декабре 2018 г. партийный съезд Христианского демократического союза избрал генерального секретаря Аннегрет Крамп-Карренбауэр новым председателем партии ${ }^{203}$.

А. Меркель уступила лидерство в партии, чтобы вернуть себе доверие как к лидеру страны. Она пожертвовала ме́ньшим, чтобы сохранить большее. На наш взгляд, Меркель прекрасно понимала, что данный шаг вызовет уважение со стороны коллег и конкурентов, которые, соблюдая правила политической корректности, будут вынуждены вспомнить её заслуги как председателя партии и выразить ей публичное уважение, что будет способствовать укреплению её авторитета. К тому же, взяв ответственность за неудачи ХДС на себя, она продемонстрировала образец политического мужества своим оппонентам, и, прежде всего, Х. Зеехоферу, который долго держался за пост главы $\mathrm{XCC}$, но под давлением коллег по партии последовал её примеру. Важно понимать, что решение А. Меркель было призвано спасти её канцлерство в труднейшей внутриполитической ситуации.

Таким образом, уход А. Меркель с поста председателя Христианско-демократического союза после 18 лет руководства открыл для партии и Германии новую главу. Выбор преемника не только начало обновления партийно-политической элиты, определение направления, в котором будет развиваться в будущем партия, это борьба за наследство А. Меркель и будущее канцлерство.

203 По итогам голосования на съезде ХДС 7 декабря 2018 г. А. Крамп-Карренбауэр была избрана новым председателем партии, получив 51,75\%, её оппонент Ф. Мерц набрал 48,25\%. Подробнее см.: Басов Ф. Выборы председателя ХДС - важнейшее событие в процессе передачи власти в ФРГ. Экономика и политика Германии: через год после выборов. Отв. ред. Е.П. Тимошенкова. М., ИЕ РАН, 2019. С. 56-62. 


\section{ЗАКЛЮЧЕНИЕ}

В 2005 г. А. Меркель стала канцлером объединённой Германии, выиграв федеральные выборы у СДПГ с минимальным перевесом в 1\%. Предположить, что консервативные немецкие избиратели отдадут своё предпочтение женщине - политику из ГДР в тех условиях было очень сложно. Ещё труднее - предсказать, что она уверенно выиграет следующие выборы в бундестаг в 2009, 2013 и 2017 гг. А. Меркель удалось стать канцлеромдолгожителем и войти в историю ФРГ наряду с известными лидерами ХДС - К. Аденауэром и Г. Колем. Свою первую победу она одержала не потому, что была сильнее и граждане Германии хотели видеть её главой государства, а потому что соперник оказался слабее. Те выборы выиграл Христианско-демократический союз, а А. Меркель извлекла уроки на будущее: следовать настроениям избирателей, перехватывая инициативу у других партий, расширять электоральную базу, не спешить с принятием решений и не экспериментировать с социальным государством.

С 2005 г. христианские демократы под руководством канцлерин не раз корректировали свою политику и программу с целью привлечь к ХДС сторонников других партий, прежде всего, СДПГ. Успехи коалиций во многом оказались возможны благодаря предыдущим реформам социал-демократов и их ответственной работе в правительстве А. Меркель. Однако канцлерин всегда удавалось представить общие заслуги, как достижения её партии. И социал-демократы, и либералы по окончании легислатурных периодов теряли голоса на следующих выборах. В итоге к 2017 г. ХДС не только обошёл конкурентов по количественным показателям, но и добился устойчивого признания среди различных по политическим воззрениям и социальной принадлежности граждан, завоевав доверие в вопросах, традиционно относящихся к профессиональной сфере других партий. И это, во многом, личный результат ее председателя А. Меркель.

ХДС под руководством канцлерин стал менее консервативным и многопрофильным - партии удалось перехватить темы, традиционно относящиеся к сфере СДПГ и «зелёных». С одной стороны, такая тактика расширила возможности союза по выбо- 
ру партнёра для заключения коалиций. С другой - дезориентировала избирателей, которым трудно понять, какое направление ХДС выберет в будущем, и будет ли придерживаться своих обещаний после победы на выборах. Сильная зависимость Христианско-демократического союза от политических взглядов и решений одного человека привела к отождествлению успеха или поражения партии с личностью А. Меркель и поставила вопрос о будущем ХДС без канцлерин и о том, в каком направлении поведёт партию её преемник.

Провозгласив целью ХДС завоевать политический центр и стать «партией середины», А. Меркель сумела превратить его в самого сильного игрока на политической арене объединённой Германии. Её «социал-демократизация» ХДС, оказалась успешнее, чем поворот СДПГ «вправо», который предпринял Г. Шрёдер, решившись на «Повестку дня 2010». Однако сместившись влево и присоединив к Христианско-демократическому союзу избирателей из другого лагеря (СДПГ и «Союза 90/Зелёные»), она не только вызвала недовольство среди собственных однопартийцев, которые восприняли её курс как отход от традиционных христианских ценностей и образовали оппозицию, но и подготовила условия для появления новой партии на правом фланге - «Альтернативы для Германии».

Созданная как альтернатива правительственному курсу А. Меркель по спасению еврозоны в 2013 г. «АдГ» быстро усилилась. Этому способствовала критика политики «открытых дверей», которую провозгласила канцлерин в 2015 г. по отношению к иммигрантам. Решение А. Меркель в период обострения миграционного кризиса принять большое количество беженцев в Германии раскололо немецкое общество пополам и привело к всплеску радикальных настроений. Начав свой старт как протестная партия, право-популистская «Альтернатива для Германии» превратилась к 2017 г. не только в самую большую оппозиционную фракцию в бундестаге, но и составила существенную конкуренции всем этаблированным немецким партиям. Она входит в парламенты всех федеральных земель, а в некоторых из них, прежде всего, на Востоке Германии, - вторая политическая сила после ХДС. Неслучайно, победив на выборах в бун- 
дестаг в 2017 г., А. Меркель назвала «АдГ» главным вызовом для партийно-политической системы. Таким образом, смещение настроений немецкого избирателя вправо и успех право-популистской «Альтернативы для Германии» стали следствием политического курса канцлерин и её личного решения о принятии беженцев в 2015 г.

Анализ земельных и федеральных выборов в Германии в рассматриваемый период позволяет сделать вывод, что в партийно-политической системе ФРГ обозначилась новая конфликтная линия. Финансовый кризис 2008-2009 гг., миграционная волна 2015 г. и дебаты о защите климата разделили немецкое общество независимо от их прежних политических предпочтений и социально-экономического положения. Если раньше одним из основных мотивов принятия решения при голосовании была уверенность граждан в стабильности своего положения и устойчивая экономическая ситуация в Германии, то теперь тревога за будущее: те, кто довольны днём сегодняшним, испытывают опасения перед завтрашним. Таким образом, новый конфликт проходит через всё немецкое общество, затрагивает социально-экономический срез и делит население в зависимости от отношения к традиционным культурным ценностям на сторонников модернизации/глобализации и её противников. Одни в силу экономических, социальных, культурных обстоятельств усматривают в модернизации угрозу для своего будущего и опасаются, что их достижения не будут признаны в эпоху цифровой экономики, а социальные льготы и поддержку государства придётся делить с иммигрантами. Другие открыты к переменам и рассматривают их как шанс. При этом партийно-политическая система в старых и новых землях Германии развивается по-разному. Для жителей бывшей ГДР характерны не только протестные настроения, которые успешно аккумулирует правопопулистская «Альтернатива для Германии», но и более заметные электоральные симпатии к партии «Левая».

Избрание в бундестаг в 2017 г. «АдГ» во многом объясняется протестным голосованием, обусловленным недовольством миграционной политикой правительства и отсутствием у народных партий новых прорывных идей. Отток избирателей от этаб- 
лированных партий и их нежелание сотрудничать с новым политическим игроком вынуждает партии заключать непривычные для них союзы. В ближайшем будущем по итогам земельных и федеральных выборов возможны любые комбинации, за исключением коалиций с «АдГ» и союза, в который войдут ХДС/ХСС и партия «Левая» ${ }^{204}$. Подобная неопределённость дезориентирует избирателей, которые часто отдают свой «второй голос» за малые партии, чтобы помочь крупному игроку создать желаемую коалицию. Можно предположить, что в перспективе партии постараются вернуться к традиционной борьбе между «левым» и «консервативным» блоками.

Наиболее широкие возможности в этой связи у «Союза 90/ Зелёные»: он может войти в состав правительства, возглавляемого как СДПГ, так и ХДС. Участие в коалициях с этими партиями на земельном уровне дало им хороший опыт. К тому же тему защиты экологии - визитную карточку «зелёных», используют теперь все политические силы. В вопросах экономики и финансов, социальной политики, роли государства в программах СДПГ, ХДС и «Союза 90/Зелёные» можно найти достаточное количество пунктов для сближения. Это повышает политический вес партии и делает её более привлекательным партнёром не только для СДПГ, но и для ХДС.

Провал первого раунда зондирующих переговоров между ХДС/ХСС, «Союзом 90/Зелёные» и «СвДП» в 2017 г. привёл к необходимости вернуться к идее большой коалиции. Однако результаты выборов в некоторых федеральных землях и отток избирателей от социал-демократов не позволяют исключить ситуацию, при которой две народные партии не сумеют в будущем набрать более 50\% голосов и будут вынуждены вступать в союзы с двумя малыми партиями. Для СДПГ в этой связи актуальной становится кооперация на федеральном уровне с левыми - опция, от которой они до сих пор отказывались. Но даже этого союза теряющим популярность социал-демократам не до-

204 Подробнее о возможных комбинациях см.: Рубинский Ю.И., Ананьева Е.В., Тимошенкова Е.П., Верников В.Л., Швейцер В.Я., Плевако Н.С., Ведерников М.В., Шишелина Л.Н., Кандель П.Е. Об основных партийно-политических процессах в современных государствах. Современная Европа №1(73), 2017. C. $116-123$. 
статочно для образования правительственной коалиции. Поэтому речь пойдёт о заключении соглашения между тремя партиями левого спектра: СДПГ, «Союз 90/Зелёные» и «Левая». Пребывание СДПГ в больших коалициях, ошибки её лидеров и превращение ХДС под руководством А. Меркель в партию политического центра привели к тому, что старейшая социалистическая партия Германии теряет свой «народный» статус и рискует перейти во второй эшелон. Трудность образования правительственных коалиций на земельном уровне и шаткое равновесие на федеральном демонстрируют востребованность для блока ХДС/ХСС сильной СвДП, которой пока не удаётся восстановить свои позиции. Чем ниже доверие немецких граждан к ХДС и СДПГ, тем крепче они привязаны к большой коалиции. Партии не готовы к новым федеральным выборам и поэтому будут стараться сохранить «статус-кво». Участие в правительстве, несмотря на его вынужденный характер, превратилось для них в гарантию стабильности на фоне набирающей популярность «АдГ».

Таким образом, успех «Альтернативы для Германии» и потери этаблированных партий выводят партийно-политическую систему на новый этап развития и затрудняют прогноз итогов последующих земельных и федеральных выборов. «АдГ» смогла стать конкурентом для всех традиционных игроков. С одной стороны, её успех привёл к обострению партийных дискуссий, поскольку теперь в парламенте ФРГ представлены практически все политические течения и социальные группы. С другой, заставляет партии учитывать тенденцию «поправения» электората и вынуждает пересмотреть позиции по ряду вопросов: приём беженцев и интеграция, поддержка слабо защищённых социальных слоёв, развитие ЕС и т.д. В будущем для христианских демократов может встать вопрос о сотрудничестве с «АдГ» на земельном уровне, если традиционные коалиции не будут набирать необходимое большинство голосов, а уровень доверия населения к новой партии вырастет. Легислатурный период 20172021 гг. - хорошая возможность для «Альтернативы» проявить себя в качестве конструктивной оппозиционной силы, закрепиться в партийно-политической системе ФРГ и со временем 
эволюционировать в классическую консервативную партию.

Таким образом, влияние А. Меркель как председателя Христианско-демократического союза и канцлера Германии на развитие партийно-политической системы ФРГ оказалось неоднозначным. С одной стороны ей удалось превратить ХДС в партию «середины» и вытеснить с политического центра основного конкурента - СДПГ, что способствует утрате этой старейшей немецкой партии «народного статуса». С другой стороны, её политика содействовала усилению правых настроений в немецком обществе и возникновению новой право-популистской партии «Альтернатива для Германии». Это неизбежно ведёт к серьёзным изменениям в партийно-политическом ландшафте ФРГ и сдвигает партии в борьбе за избирателя на правый фланг. Преимущества, достигнутые ХДС при председателе А. Меркель, её преемники могут быстро растерять, т.к. им придётся делать сложный выбор - продолжить модернизацию партии или вернуться к консервативным истокам. Бороться за избирателя они будут вынуждены в новых политических условиях, которые оставит после себя канцлер А. Меркель. 


\section{ОСНОВНАЯ ЛИТЕРАТУРА}

1. Басов Ф.А. Выборы председателя ХДС - важнейшее событие в процессе передачи власти в ФРГ. Экономика и политика Германии: через год после выборов. Под ред. Е.П. Тимошенковой. М.: ИЕ РАН, 2019. С. 56-62.

2. Васильев В.И. «Меркализация» СДПГ: отход от «восточной политики» В. Брандта. Международная жизнь. 2018. №9. С. 4764.

3. Васильев В.И. Гельмут Коль. Прагматик, патриот, европеец. Международная жизнь. 2017. №7. С. 43-53.

4. Васильев В.И. Германский политик Герхард Шрёдер. Новая и новейшая история. 2014. №6. С. 145-157.

5. Германия. Вызовы XXI века. Под ред. В.Б. Белова. М.: Весь Мир, 2009. 788 с.

6. Деревянченко А.А. Три жизни Ангелы Меркель: обычная, пропедевтическая, триумфальная. Политическая и личная биография первой женщины - федерального канцлера. М.: Изд. Ленанд, 2017. 288 с.

7. Камкин А.К. «Альтернатива для Германии» - партия-однодневка или серьёзная сила? Современная Германия: экономика и политика. Под ред. В.Б. Белова, М.: ИЕ РАН, Весь мир, 2015. С. 533-539.

8. Камкин А.К. «Альтернатива для Германии» - прообраз народной партии нового типа? Германия. 2014. Под ред. В.Б. Белова. М.: ИЕ РАН, 2015. С. 51-61.

9. Камкин А.К. «Альтернатива для Германии» - как новый элемент партийного ландшафта. Современная Европа. 2015. №2 (62). С. 118-122.

10. Меден Н.К. Парламентские партии против вируса популизма. Германия. 2016. Под ред. В.Б. Белова. М.: ИЕ РАН, 2017. С. 42-43.

11. Меркель - недальновидный и опасный политик, Шрёдер человек из прошлого. The Financial Times, 08.09.2005.

12. Павлов Н.В. «Союз 90/Зелёные»: история, состояние, перспективы. Мировая экономика и международные отношения. 2011. №3. С. 37-45. 
13. Павлов Н.В. Меркель 4.0 - это реальность! Historia provinсіае - журнал региональной истории. 2018. Т. 2. №2. С. 80-90. 14. Павлов Н.В. Политическое лидерство в условиях канцлерской демократии. Мировая экономика и международные отношения. 2011. №11. С. 25-38.

15. Павлов Н.В. Эволюция партийной системы ФРГ: роль малых партий. Роль малых партий в партийно-политической системе Германии. Под ред. В.Б. Белова, Е.П. Тимошенковой. М.: ИЕ PAH, 2015. С. 28-49.

16. Павлов Н.В. Германия после Меркель (Ждать ли изменений во внешней политике ФРГ?). Полис. Политические исследования. 2019. №6. С. 22-35.

17. Павлов Н.В. Германский федерализм: опыт реформирования. Мировая экономика и международные отношения. 2007. №10. С. 53-63.

18. Павлов Н.В. История современной Германии. 1945-2005. М.: АCТ, 2006. $366 \mathrm{c}$.

19. Павлов Н.В. Нормальная и «ненормальная» Германия. Международная жизнь. 2005. №11. С. 15-31.

20. Погорельская С.В. «Альтернатива для Германии»: без внутренней альтернативы? Перспективы. 2018. №1(13). С. 40-55.

21. Погорельская С.В. Левая альтернатива для Германии. Актуальные проблемы Европы. 2019. №4. С. 78-92.

22. Погорельская С.В. Опыт и уроки германской иммиграционной политики. Актуальные проблемы Европы. 2015. №4. С. 6184.

23. Погорельская С.В. Современный германский популизм: общее и особенное. Перспективы. 2019. №4(20). С. 92-102.

24. Рубинский Ю.И., Ананьева Е.В., Тимошенкова Е.П., Верников В.Л., Швейцер В.Я., Плевако Н.С., Ведерников М.В., Шишелина Л.Н., Кандель П.Е. Об основных партийно-политических процессах в современных государствах. Современная Европа №1(73). 2017. С. 116-123.

25. Синдеев А.А. Новые тенденции в политической системе Германии. Европа 2017: партии, выборы, власть. М., ИЕ РАН, 2018. C. $36-42$. 
26. Современная Германия: экономика и политика. Под ред. В.Б. Белова, М.: ИЕ РАН; Весь мир, 2015. 717 с.

27. Тимошенкова Е.П. Выбор «большого города» итоги избирательных кампаний 2015 г. в Бремене и Гамбурге. Германия 2015. Ч. ІІ. Под ред. В.Б. Белова. М.: ИЕ РАН, 2016. С. 24-30.

28. Тимошенкова Е.П. Большая коалиция и концепция преодоления миграционного кризиса. Германия 2015. Ч. ІІ. Под ред. В.Б. Белова. М.: ИЕ РАН, 2016. С. 45-55.

29. Тимошенкова Е.П. Выборы в германский парламент: основные результаты и их влияние на партийно-политическую систему Германии. Германия. 2013. Под. ред. В.Б. Белова. М.: ИЕ PAH, 2014. C. 11-34.

30. Тимошенкова Е.П. Итоги выборов в бундестаг: новые вызовы - старые ответы. Современная Европа. 2018. №2(81). С. 2939.

31. Тимошенкова Е.П. Особенности партийно-политического развития ФРГ, Германия. 2011. Под ред. Белова В.Б. М.: ИЕ PAH, 2012. C. 53-77.

32. Тимошенкова Е.П. Особенности партийно-политического развития ФРГ и миграционный кризис 2015-2016 гг. Трансформация партийно-политического ландшафта в странах Евросоюза в условиях кризиса. М.: ИЕ РАН, 2017. С. 20-34.

33. Тимошенкова Е.П. Особенности стратегии «народных партий» в избирательной кампании в бундестаг 2017 г. и формирование правительства. Германия. 2017. Под ред. В.Б. Белова. М.: ИЕ РАН, 2018. С. 105-114.

34. Тимошенкова Е.П. «Тенденции партийно-политического развития Германии: итоги выборов в европейский парламент и особенности избирательных кампаний в ландтаги». Германия 2014. Ч. 2. Политика. Под. ред. В.В. Белова. М.: ИЕ РАН, 2015. C. 4-20.

35. Тимошенкова Е.П. Германия 2012 - предвыборное настроение (за год до федеральных выборов) Германия. 2012. Ч. І. Под ред. В.Б. Белова. М.: ИЕ РАН, 2013. С. 47-84.

36. Тимошенкова Е.П. Партийно-политическое развитие ФРГ шансы и риски чёрно-жёлтой коалиции. Германия. 2010. Под ред. В.Б. Белова. М.: ИЕ РАН, 2011. С. 10-33. 
37. Тимошенкова Е.П. Формула власти А. Меркель: почему канцлерин отказалась от поста председателя партии ХДС. Экономика и политика Германии: через год после выборов. Под ред. Е.П. Тимошенковой. М.: ИЕ РАН, 2019. С. 49-56.

38. Фёдоров В.П. Роль Германии в судьбе европейского проекта. Экономика и политика Германии: через год после выборов. Под ред. Е.П. Тимошенковой. М.: ИЕ РАН, 2019. С. 7-13.

39. Хорольская М.В. Преодоление прошлого и переосмысление истории ГДР в современной Германии. Россия и современный мир. 2019. №1(102). С. 133-147.

40. Хорольская М.В. Проблемы формирования единой идентичности в Германии после воссоединения. Этносоциум и межнациональная культура. 2017. №3(105). С. 158-162.

41. Хорольская М.В. Различия в политической культуре Востока и Запада Германии в условиях кризисов ЕС. Мировая экономика и международные отношения. 2017. Т. 61. №9. С. 100-110. 42. Alternative für Deutschland. Die Strategie der AfD für das Wahljahr 2017. Berlin, $22 \mathrm{~S}$.

43. Bannas G. Machtverschiebung. Wie die Berliner Republik unsere Politik verändert hat. Propyläen. Berlin, 2019. 335 S.

44. Blome N. Angela Merkel die Zauder -Künstlerin. Pantheon. München, 2013. 206 S.

45. Borchsard M., Stoze S. Einzug der Piratenpartei in das Berliner Abgeordnetenhaus - eine Analyse des Wahlergebnisses. Parteimonitor Aktuell. Konrad-Adenauer Stiftung. Berlin, 21.09.2011. 19 S. 46. Boysen Ja. Angela Merkel. Eine Karriere. Ullstein. Berlin, 2005. 135 S.

47. Bundestagswahl in Deutschland am 22.09.2013. Wahlanalyse von Viola Neu. Konrad-Adenauer-Stiftung. Berlin, 2013. 14 S.

48. Christian v. Ditfurth. SPD - eine Partei gibt sich auf. Henschel Verlag. Berlin, 2000. $352 \mathrm{~S}$.

49. Das Grundsatzprogramm der CDU «Freiheit und Sicherheit. Grundsätze für Deutschland» beschlossen vom 21 Parteitag im Hannover 3-4 Dezember 2007. 179 S.

50. Demokratie wieder herstellen. Dem Volk die Staatsgewalt zurück geben. AfD - Manifest 2017. Berlin, 2017. 14 S. 
51. Dempsey Ju. Das Phänomen Merkel - Deutschlands Macht und Möglichkeiten. Edition Körber-Stiftung. Hamburg, 2013. 302 S.

52. FDP nach der Berlin-Wahl. Euro-Skeptiker a.D. von Severin Weiland. Spiegel am 19.09.2011.

53. Forum Empirische Sozialforschung. Wählen, wählen, immer wieder wählen. Die Bundestagwahl und Europawahl im Vergleich. Von Viola Neu, Sabine Pokorny. Konrad-Adenauer-Stiftung. EV Sankt Augustin/Berlin, 2014. 22 S.

54. Grünen-Parteitag. Beschlüsse aus Hannover. am 18.11.2012. 6 S. 55. Gemeinsam für Deutschland. Mit Mut und Menschlichkeit. Koalitionsvertrag von CDU, CSU und SPD. Berlin, 2005. 147 S.

56. Hamburger Programm. Grundsatzprogramm der Sozialdemokratischen Partei Deutschlands. Beschlossen auf dem Hamburger Bundesparteitag der SPD am 28. Oktober 2007. 115 S.

57. Höller G. Die Patin. Wie Angela Merkel Deutschland umbaut. Orell Füssli. Zürich, 2012. 184 S.

58. Landtagswahl in Nordrhein-Westfalen am 13.05.2012. Wahlanalyse. Konrad Adenauer Stiftung. Berlin, 2012. 8 S.

59. Langguth G. A. Merkel. Aufstieg zur Macht. Dtv. München, 2005. 314 S.

60. Leinemann Jü. Höhenrausch. Die wirklichkeitsleere Welt der Politiker. Heyne. München, 2004. 188 S.

61. Lohmann M. Das Kreuz mit dem C. Wie christlich ist die Union? Butzon\&Bercker, Kevelar. 2009. 155 S.

62. Manfred O. Martin Schulz Der Kandidat. Die Biografie. Verlag Herder GmbH Leipzig, 2017. 213 S.

63. Merkel A. Ich habe Antworten. Spiegel-Gespräch. Der Spiegel. №2. 09.01.2006.

64. Merkel A. u. a. In unruhiger Zeit. Reden und Aufsätze aus drei Jahren deutscher Einheit. Düsseldorf-Bonn, 1994. 114 S.

65. Merkel A. Mein Weg. Angela Merkel im Gespräch mit HugoMüller-Vogg. Hoffmann und Campe. Hamburg, 2004. 132 S.

66. Mihael B., Stoze S. Einzug der Piratenpartei in das Berliner Abgeordnetenhaus - eine Analyse des Wahlergebnisses. Parteimonitor Aktuell. Konrad-Adenauer Stiftung. Berlin, 21.09.2011. 19 S. 67. Neu V. Bundestagswahl in Deutschland am 27. September 2009. Wahlanalyse. Konrad-Adenauer Stiftung. Berlin, Dezember 2009. 
$22 \mathrm{~S}$.

68. Neu V. Bürgerschaftswahl in Bremen am 10. Mai 2015. Wahlanalyse. Konrad-Adenauer Stiftung. Hauptabteilung Politik und Beratung. Berlin, Februar 2015. 11 S.

69. Neu V. Landtagswahl in Brandenburg am 14. September 2014. Wahlanalyse. Konrad-Adenauer Stiftung. Berlin, 2014. 12 S.

70. Neu V. Landtagswahl in Sachsen am 31.08.2014. Wahlanalyse. Konrad-Adenauer Stiftung. Berlin, 2014. 8 S.

71. Neu V., Pokorny S. Bundestagswahl in Deutschland am 24.09. 2017. Wahlanalyse. Konrad-Adenauer Stiftung. Berlin, 2017. 22 S.

72. Osang N. Die Schläferin. Der Spiegel. 2009. №46. S 5-9.

73. Platzeck M., Steinmeier F.-W., Steinbrück P. (Hg). Auf der Höhe der Zeit - Soziale Demokratie und Fortschritt im 21. Jahrhundert. Vorwärts Buch. Berlin, 2007. 224 S.

74. Robin A. Die Getriebenen. Merkel und die Flüchtlingspolitik: Reports aus dem Inneren der Macht. Siedler Verlag. München, 2017. $287 \mathrm{~S}$.

75. Schmiese W. Konservativ im Herzen - progressiv im Geist. F.A.Z., 06.09.2007, №207. S. 1-4.

76. Schumacher H. Die zwölf Gesetze der Macht. Angela Merkels Erfolgsgeheimnisse. Karl Blessig. München, 2006. 188 S.

77. Volker R. Angela Merkel Die Protestantin. Ihr Aufstieg, ihre Krisen - und jetzt? Verlag Herder. Freiburg, Wien, 2017. 267 S.

78. Weiland S. FDP nach der Berlin-Wahl. Euro-Skeptiker a.D. Spiegel. am 19.09.2011. 


\section{ОБ АВТОРЕ}

Тимошенкова Екатерина Петровна - кандидат исторических наук, ведущий научный сотрудник Отдела страновых исследований, заместитель руководителя Центра германских исследований Института Европы РАН. Окончила с отличием Смоленский Педагогический Университет, факультет «история и право» (2001 г.). В 2007 г. защитила кандидатскую диссертацию. Многократно проводила научные исследования в Германии, в т.ч. в университете им. Георга Августа (г. Гёттинген, 2014, 2015 гг.), Академии политического образования (г. Тутцинг, 2008 г.), Институте новейшей истории (г. Берлин, 2005-2006 гг.). В 2009 г. при поддержке фонда им. Конрада Аденауэра стажировалась в бундестаге ФРГ, бюро заместителя председателя ХДС/ХСС д-ра Андреаса Шоккенхофа, координатора германо-российского сотрудничества гражданских обществ. В 2008-2009 гг. стала лауреатом конкурса «Лучшие учёные. Кандидаты и доктора наук Российской академии наук», член правления Общества «Россия и Германия». Автор более 60 научных публикаций по вопросам партийно-политической системы ФРГ и российско-германских отношений.

\section{ABOUT THE AUTHOR}

Timoshenkova Ekaterina Petrovna - PhD in Historical Science, leading researcher of the Department of country studies, Deputy Head of the Center of German studies of Institute of Europe of Russian Academy of Sciences. Graduated with honors from the Smolensk Pedagogical State University, Faculty of History and Law (2001). She defended her $\mathrm{PhD}$ thesis in 2007. Repeatedly conducted research in Germany, including at the Georg August University (Göttingen, 2014, 2015), the Academy of Political Education (Tutzing, 2008), the Institute of Contemporary History (Berlin, 2005-2006). In 2009, with the support of the Konrad Adenauer Foundation trained in the Parliament of the Federal Republic of Germany German Bundestag, the office of the Deputy Chairman of the CDU/CSU, Dr. Andreas Schockenhof, Coordinator for the German-Russian cooperation in civil societies. She became the winner of the contest «Best Scientists. PhDs and Doctors of Sciences of the Russian Academy of Sciences» in 2008-2009, member of the Board of the Society «Russia and Germany». The author of more than 60 scientific publications on the party-political system of Germany and Russian-German relations. 


\section{В 2018-2020 гг. были выпущены следующие доклады Института Европы}

350. Большое Причерноморье: на перекрёстках сотрудничества и конфликтов. Отв. ред. Д.А.Данилов. ДИЕ РАН № 350. М., 2018 г. 351. Будущее Европы: глобальные вызовы и возможные ответы. Отв. ред. Л.О.Бабынина. ДИЕ РАН № 351. М., 2018 г.

352. В.С.Циренщиков. Прогностическая деятельность европейских компаний. ДИЕ РАН № 352. М., 2018 г.

353. Европа 2017: партии, выборы, власть. Отв. ред. В.Я.Швейцер. ДИЕ РАН № 353. М., 2018 г.

354. Германия. 2017. Под ред. В.Б.Белова (отв. ред.) и др. ДИЕ РАН № 354, М., 2018 г.

355. Ю.А.Борко. Восточное партнёрство: проект, реальность, будущее. ДИЕ РАН № 355. М., 2018 г.

356. Правительство меньшинства Терезы Мэй - год у власти. Отв. ред. Е.В.Ананьева. ДИЕ РАН № 356. М., 2018 г.

357. Партии и движения политической альтернативы в современной Европе. Отв. ред. В.Я.Швейцер. ДИЕ РАН № 357. М., 2018 г.

358. И.С.Гладков, Е.Ю.Горбатенко. Внешняя торговля Европейского союза: особенности на современном этапе. ДИЕ РАН № 358. М., 2018 г.

359. А.И.Бажан. Перспективы евроинтеграции: валютно-финансовые аспекты. ДИЕ РАН № 359. М., 2018 г.

360. Экономика и политика Германии: через год после выборов. Отв. ред. Е.П.Тимошенкова. ДИЕ РАН № 360. М., 2019 г.

361. Германия. 2018. Под ред. В.Б.Белова (отв. ред.) и др. ДИЕ РАН № 361. М., 2019 г.

362. Свет и тени «эры Макрона». Отв. ред. В.Я. Швейцер. ДИЕ РАН № 362. М., 2019 г.

363. Большое Причерноморье: политика, экономика, безопасность. Отв. ред. О.В.Буторина. ДИЕ РАН № 363. М., 2019 г.

364. Итоги правления Терезы Мэй. Под ред. Е.В.Ананьевой. ДИЕ РАН № 364. М., 2019 г.

365. П.В.Осколков. Правый популизм в Европейском союзе. ДИЕ РАН № 365. М., 2019 г.

366. А.И.Шумилин. Ближневосточные конфликты: европейский подход. ДИЕ РАН № 366. М., 2019 г.

367. И.Н.Щербак. Роль ООН, ЕС и ОБСЕ в кризисном урегулировании. ДИЕ РАН № 367. М., 2019 г.

368. Германия. 2019. Отв. ред. В.Б.Белов. ДИЕ РАН № 367. М., 2020 г. 


\section{«Reports of Institute of Europe» published in 2018-2020}

350. The Wider Black Sea Region: at the Crossroads of Cooperation and Conflicts. Ed. by D.A.Danilov. Reports of the IE RAS, № 350. M., 2018. 351. The Future of Europe: global challenges and possible responses. Ed. by L.O.Babynina. Repotrs of the IE RAS, № 351. M., 2018.

352. V.S.Tsirenshchikov. Prognostic Activities of European Companies. Repotrs of the IE RAS, № 352. M., 2018.

353. Europe 2017: parties, elections, power. Ed. by V.Ya.Shveitser. Reports of the IE RAS, № 353. M., 2018.

354. Germany. 2017. Ed. by V.B.Belov and others. Reports of the IE RAS, № 354. M., 2018.

355. Yu.A.Borko. The Eastern Partnership: project, realities, future. Reports of the IE RAS, № 355. M., 2018.

356. Th. May's Minority Government - a Year in Power. Ed. by E.V. Ananieva. Reports of the IE RAS, № 356. M., 2018.

357. Parties and Movements of Political Alternative in Contemporary Europe. Ed. by V.Ya.Shveitser. Reports of the IE RAS, № 357. M., 2018. 358. I.S.Gladkov, E.Yu.Gorbatenko. The foreign trade of the European Union: features at the present stage. Reports of the IE RAS, № 358. M., 2018.

359. A.I.Bazhan. Prospects for European integration: monetary and financial aspects. Reports of the IE RAS, № 359. M., 2018.

360. Economy and Politics of Germany - a year after the elections. Ed. by E.P.Timoshenkova. Reports of the IE RAS, № 360. M., 2019.

361. Germany. 2018. Ed. by V.B.Belov and others. Reports of the IE RAS, № 361. M., 2019.

362. Light and Shadows of the «Macron Era». Ed. by V.Ya.Shveitser. Reports of the IE RAS, № 362. M., 2019.

363. The Wider Black Sea Region: Politics, Economy, Security. Ed. by O.V.Butorina. Reports of the IE RAS, № 363. M., 2019.

364. Theresa May's Governance - Summing Up. Ed. by E.V.Ananieva. Reports of the IE RAS, № 364. M., 2019.

365. P.V.Oskolkov. Right-Wing Populism in the European Union. Reports of the IE RAS, № 365. M., 2019.

366. A.I.Shumilin. The Middle East conflicts: European Approach. Reports of the IE RAS, № 366. M., 2019.

367. I.N.Shcherbak. The role of the UN, EU and OSCE in crisis regulation. Reports of the IE RAS, № 367. M., 2019.

368. Germany. 2019. Ed. by V.B.Belov. Reports of the IE RAS, № 368. M., 2020. 
Научное издание

Е. П. Тимошенкова

ПАРТИЙНО-ПОЛИТИЧЕСКАЯ

СИСТЕМА ГЕРМАНИИ

В ПЕРИОД КАНЦЛЕРСТВА А. МЕРКЕЛЬ

(2005-2017 гг.)

Монография

\section{Доклады Института Европы}

№ 369

Подписано в печать 20.11.2020. Формат 60×90 1/16 Бумага офсетная. Печать офсетная. Усл.-печ. л. 9,25

Тираж 300 экз. Заказ № 2276

Федеральное государственное бюджетное учреждение науки

Институт Европы Российской академии наук

125009 Россия, Москва, ул. Моховая, д. 11, стр. 3.

Тел.: 495-692-10-51, факс: 495-629-92-96.

E-mail: europe-ins@mail.ru

Web: http://www.instituteofeurope.ru

Отпечатано с готового оригинал-макета

в типографии издательства «Нестор-История»

Тел. (812) 235-15-86 